Supporting Information for:

\title{
Estimating US background ozone using data fusion
}

\author{
T. Nash Skipper ${ }^{1}$, Yongtao Hu ${ }^{1}$, M. Talat Odman ${ }^{1}$, Barron H. Henderson ${ }^{2}$, Christian Hogrefe ${ }^{2}$, \\ Rohit Mathur ${ }^{2}$, Armistead G. Russell ${ }^{1 *}$ \\ ${ }^{1}$ School of Civil \& Environmental Engineering, Georgia Institute of Technology, Atlanta, GA
} 30332, United States

${ }^{2}$ U.S. Environmental Protection Agency, Research Triangle Park, North Carolina 27709, United States

* Corresponding author: Armistead G. Russell. Email: ar70@gatech.edu

\section{SI contents:}

Pages S1-S65

Figures S1-S36

Tables S1-S19 


\section{Lateral Boundary Conditions Comparison for 2017 Simulations}
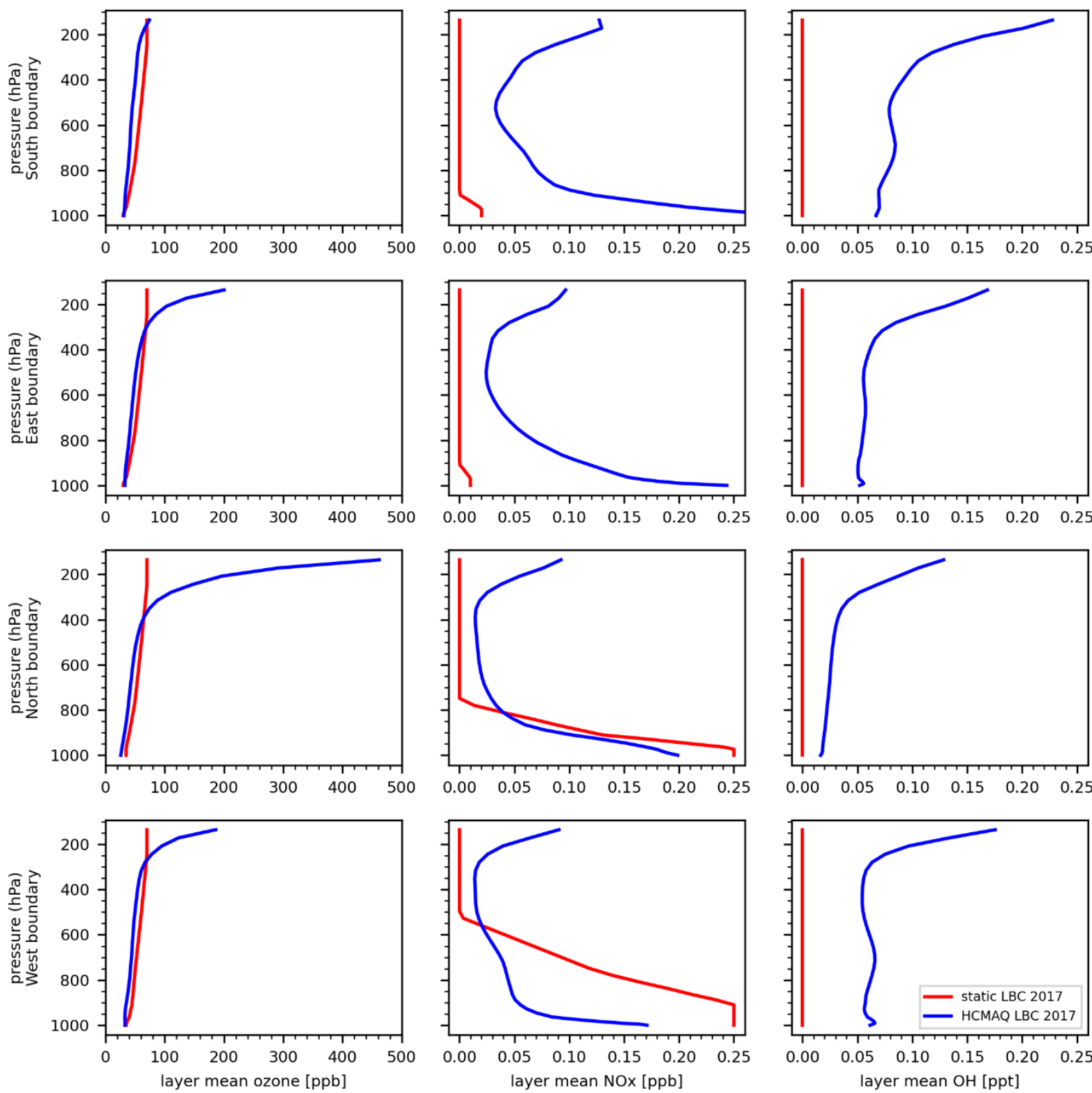

Figure S1. Comparison of static and HCMAQ LBC for $\mathrm{O}_{3}, \mathrm{NO}_{\mathrm{X}}$, and $\mathrm{OH}$. OH LBCs are likely to have very little impact on the results due to the short lifetime of $\mathrm{OH}$. 

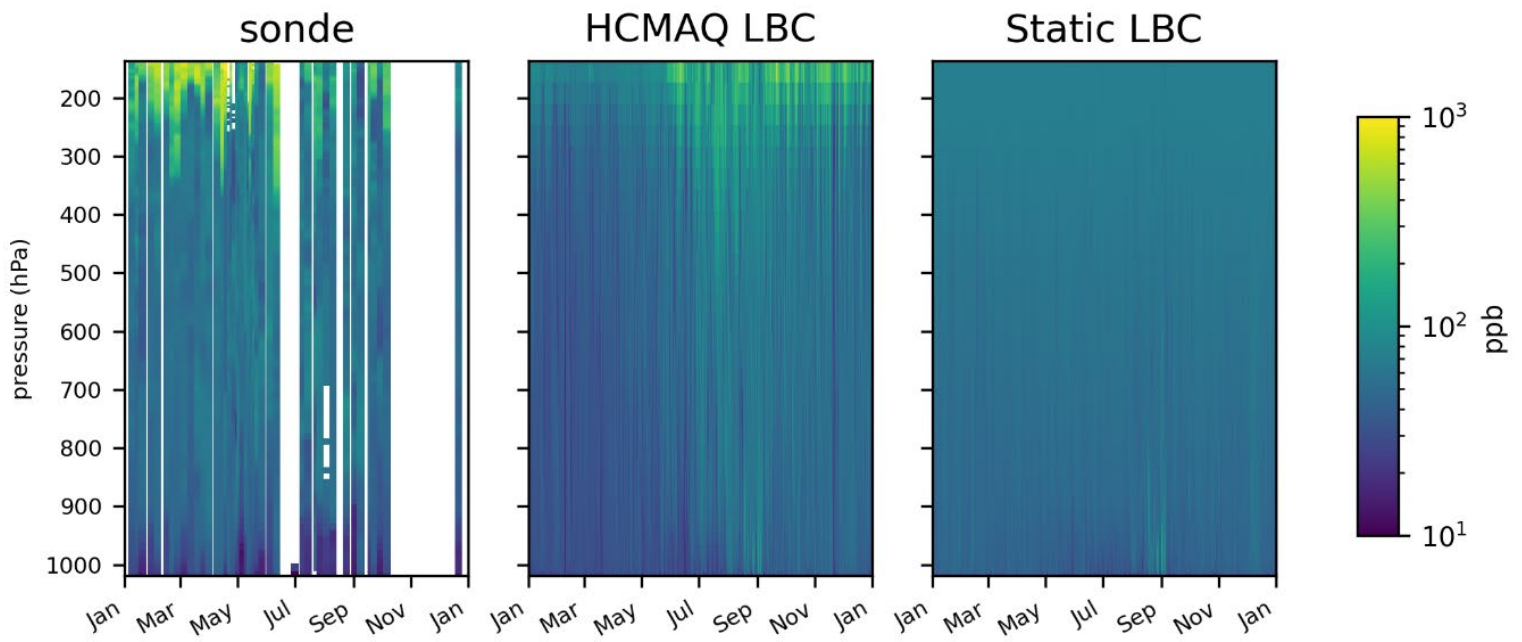

Figure S2. Vertical profile of $\mathrm{O}_{3}$ from ozonesonde and CMAQ simulations for 2017 at Trinidad Head, California (https://www.esrl.noaa.gov/gmd/). 


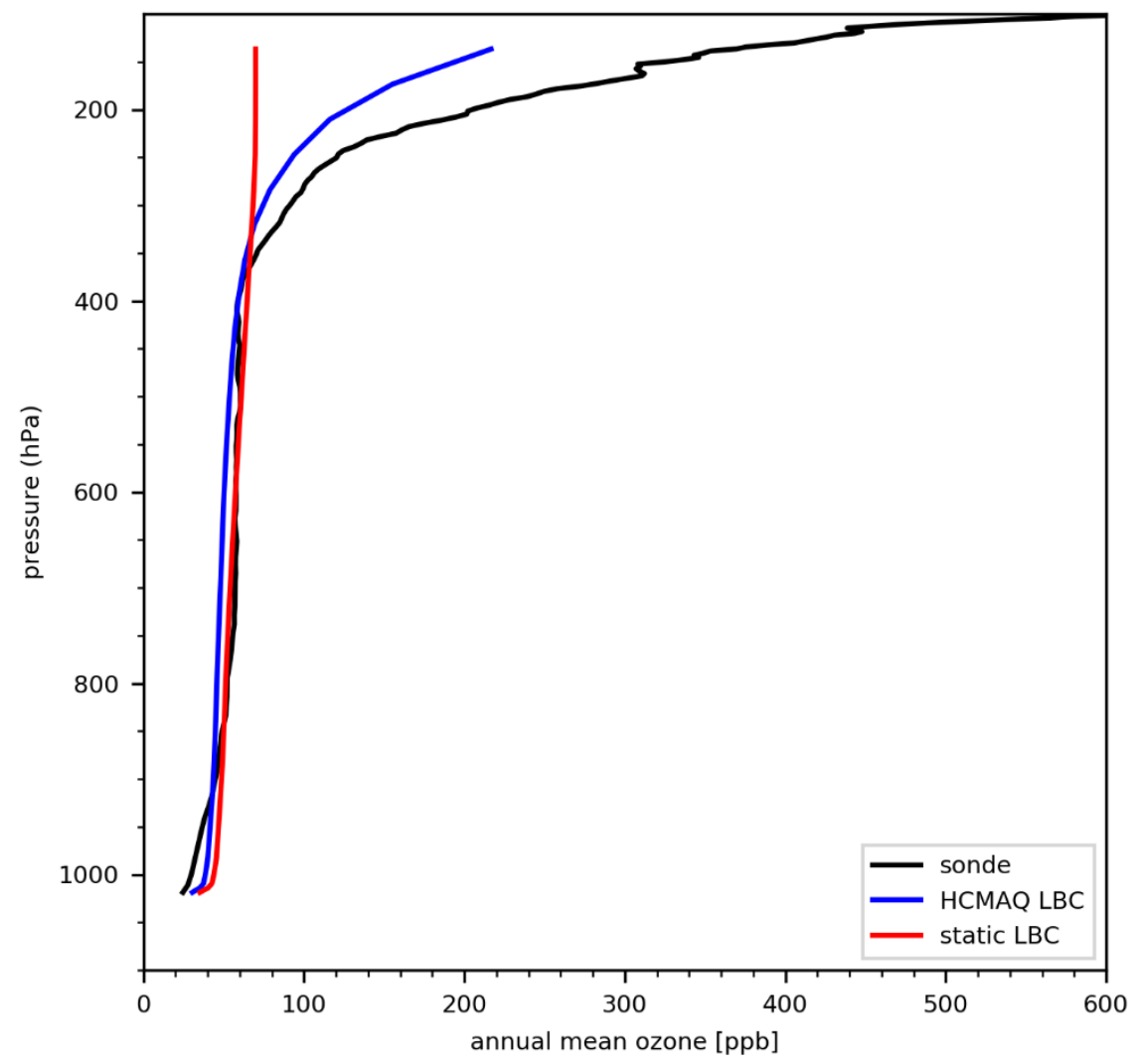

Figure S3. Annual average vertical profile of $\mathrm{O}_{3}$ from ozonesonde and CMAQ simulations for 2017 at Trinidad Head, California (https://www.esrl.noaa.gov/gmd/). 
Model domains for 2016 simulations

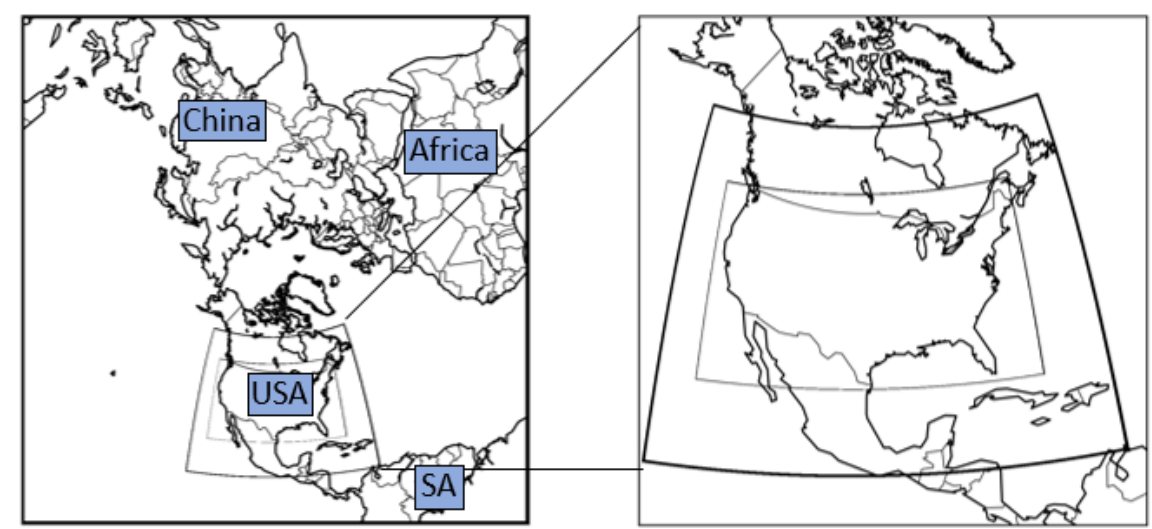

Figure S4. Domains used in 2016 simulations. The 108km HCMAQ domain (left) shows the locations of the 36 and $12 \mathrm{~km}$ nests within the hemispheric domain. A close up of North America (right) shows the $36 \mathrm{~km}$ domain in the outer bolder line and the $12 \mathrm{~km}$ domain in the inner grey line. Figure from Henderson, et al. ${ }^{1}$ 


\section{Model emission sources and configurations}

Table S1. Summary of emissions used for 2016 and 2017 hemispheric- and continental-scale CMAQ simulations.

\begin{tabular}{|c|c|c|c|c|}
\hline & $\begin{array}{c}2016 \\
\text { continental }\end{array}$ & 2016 HCMAQ & $\begin{array}{c}2017 \\
\text { continental }\end{array}$ & 2017 HCMAQ \\
\hline $\begin{array}{l}\text { US } \\
\text { anthropogenic }\end{array}$ & $\begin{array}{l}2016 \text { emissions } \\
\text { modeling } \\
\text { platform } \\
(2016 \mathrm{fe})^{2}\end{array}$ & $\begin{array}{l}2016 \text { emissions } \\
\text { modeling } \\
\text { platform } \\
(2016 \mathrm{fe})\end{array}$ & $\begin{array}{l}2011 \text { emissions } \\
\text { modeling } \\
\text { platform with } \\
\text { projections to } \\
2017(2017 \mathrm{ek})^{3}\end{array}$ & EDGAR-HTAP* \\
\hline $\begin{array}{l}\text { non-US (except } \\
\text { Canada and } \\
\text { Mexico) }\end{array}$ & from LBCs & $\begin{array}{l}\text { EDGAR-HTAP } \\
\text { projected to } \\
2014^{4} \\
\text { China: Tsinghua } \\
\text { University }{ }^{5} \\
\text { rest of Asia: } \\
\text { MIXv1 }^{6}\end{array}$ & from $\mathrm{LBCs}$ & EDGAR-HTAP \\
\hline $\begin{array}{l}\text { Canada and } \\
\text { Mexico }\end{array}$ & 2016fe & $2016 \mathrm{fe}$ & $2017 \mathrm{ek}$ & EDGAR-HTAP \\
\hline Lightning & None & GEIA** $^{* *}$ & $\begin{array}{l}\text { CMAQ inline } \\
\text { module }^{7}\end{array}$ & GEIA \\
\hline Biogenics & $\begin{array}{l}\text { Biogenic } \\
\text { Emission } \\
\text { Inventory } \\
\text { System (BEIS) }\end{array}$ & $\begin{array}{l}\text { Model of } \\
\text { Emissions of } \\
\text { Gases and } \\
\text { Aerosols from } \\
\text { Nature } \\
\text { (MEGAN), } \\
\text { except BEIS } \\
\text { over North } \\
\text { America }\end{array}$ & BEIS & GEIA \\
\hline Soil NOx & BEIS & $\begin{array}{l}\text { MEGAN, except } \\
\text { BEIS over North } \\
\text { America }\end{array}$ & BEIS & None \\
\hline Wildfires & $2016 \mathrm{fe}$ & $\begin{array}{l}\text { FINNv1.5 } \\
\text { except } 2016 \mathrm{fe}\end{array}$ & $\begin{array}{l}2017 \mathrm{NEI} \\
(2017 \mathrm{gb})^{9}\end{array}$ & FINNv1.5 \\
\hline
\end{tabular}




\begin{tabular}{|l|l|l|l|l|}
\hline & & $\begin{array}{l}\text { over North } \\
\text { America }\end{array}$ & & \\
\hline Methane & $\begin{array}{l}\text { set to constant } \\
\text { value in CMAQ } \\
(1850 \mathrm{ppb})\end{array}$ & $\begin{array}{l}\text { set to constant } \\
\text { value in CMAQ } \\
(1850 \mathrm{ppb})\end{array}$ & $\begin{array}{l}\text { set to constant } \\
\text { value in CMAQ } \\
(1850 \mathrm{ppb})\end{array}$ & $\begin{array}{l}\text { set to constant } \\
\text { value in CMAQ } \\
(1850 \mathrm{ppb})\end{array}$ \\
\hline Stratospheric $\mathrm{O}_{3}$ & $\begin{array}{l}\text { from LBCs, } \\
\text { otherwise none }\end{array}$ & $\begin{array}{l}\text { potential } \\
\text { vorticity modul } \\
\text { in CMAQ }\end{array}$ & $\begin{array}{l}\text { from LBCs, } \\
\text { otherwise none }\end{array}$ & $\begin{array}{l}\text { potential } \\
\text { vorticity module } \\
\text { in CMAQ }\end{array}$ \\
\hline $\begin{array}{l}\text { Wind-blown } \\
\text { dust }\end{array}$ & none & $\begin{array}{l}\text { CMAQ inline } \\
\text { module }\end{array}$ & $\begin{array}{l}\text { CMAQ inline } \\
\text { module }\end{array}$ & $\begin{array}{l}\text { CMAQ inline } \\
\text { module }\end{array}$ \\
\hline Sea salt & $\begin{array}{l}\text { CMAQ inline } \\
\text { module }\end{array}$ & $\begin{array}{l}\text { CMAQ inline } \\
\text { module }\end{array}$ & $\begin{array}{l}\text { CMAQ inline } \\
\text { module }\end{array}$ & $\begin{array}{l}\text { CMAQ inline } \\
\text { module }\end{array}$ \\
\hline
\end{tabular}

* https://edgar.jrc.ec.europa.eu/htap v2/

** http://www.geiacenter.org/

Table S2. Summary of model configurations used for 2016 and 2017 hemispheric- and continental-scale CMAQ simulations.

\begin{tabular}{|c|c|c|c|c|}
\hline & 2016 continental & 2016 HCMAQ & $\begin{array}{c}2017 \\
\text { continental }\end{array}$ & 2017 HCMAQ \\
\hline $\begin{array}{l}\text { CMAQ } \\
\text { model } \\
\text { version }\end{array}$ & 5.2 .1 & 5.2 .1 & 5.2 .1 & $\begin{array}{l}5.1 \text { through } \\
\text { September 23, } \\
2017 \\
5.2 \text { for the } \\
\text { remainder of } \\
2017\end{array}$ \\
\hline $\begin{array}{l}\text { Chemical } \\
\text { mechanism }\end{array}$ & cb6r3_ae6nvPOA_aq & cb6r3_ae6_aq & cb6r3_ae6_aq & $\begin{array}{l}\text { cb05e51_ae6_aq } \\
\text { through } \\
\text { September 23, } \\
2017 \\
\text { cb6r3_ae6_aq } \\
\text { for the } \\
\text { remainder of } \\
2017\end{array}$ \\
\hline
\end{tabular}




\begin{tabular}{|c|c|c|c|c|}
\hline $\mathrm{LBCs}$ & $\begin{array}{l}\text { nested from } 2016 \\
\text { HCMAQ to } 36 \mathrm{~km} \\
\text { CMAQ to } 12 \mathrm{~km} \\
\text { CMAQ }\end{array}$ & $\begin{array}{l}\text { clean conditions } \\
\text { at equator }\end{array}$ & $\begin{array}{l}\text { HCMAQ case: } \\
\text { nested from } \\
\text { 2017 HCMAQ } \\
\text { to 36km CMAQ } \\
\text { Static case: } \\
\text { static vertical } \\
\text { profile } \\
\text { distributed with } \\
\text { CMAQv5.2.1 }\end{array}$ & $\begin{array}{l}\text { clean conditions } \\
\text { at equator }\end{array}$ \\
\hline
\end{tabular}




\section{Regression Model Normalization Constants}

Table S3. Means and standard deviations of regression variables.

\begin{tabular}{|c|c|c|c|c|}
\hline & \multicolumn{2}{|c|}{2017} & \multicolumn{2}{c|}{2016} \\
\cline { 2 - 5 } & mean & $\begin{array}{c}\text { standard } \\
\text { deviation }\end{array}$ & mean & $\begin{array}{c}\text { standard } \\
\text { deviation }\end{array}$ \\
\hline X (Longitude) & -95.01 & 15.72 & -95.38 & 15.97 \\
\hline Y (Latitude) & 37.65 & 4.73 & 37.51 & 4.79 \\
\hline$Z$ (elevation in m) & 468.9 & 593.9 & 441.5 & 572.7 \\
\hline $\sin \left(\mathrm{d}^{*} 2 \pi / 365\right)$ & 0.02 & 0.73 & -0.02 & 0.72 \\
\hline $\cos \left(\mathrm{d}^{*} 2 \pi / 365\right)$ & -0.13 & 0.68 & -0.14 & 0.68 \\
\hline
\end{tabular}




\section{Extended CTM Performance Evaluation}

Performance metrics are listed below. Subscript $j$ represents the pairing of $N$ observations $O$ and predictions $P$ by site and time. Overbars represent the mean over all sites and times.

$$
\begin{aligned}
& \mathrm{MB}=\text { mean bias } \\
& \mathrm{ME}=\text { mean error } \\
& \mathrm{NMB}=\text { normalized mean bias } \\
& \mathrm{NME}=\text { normalized mean error } \\
& \mathrm{RMSE}=\text { root mean square error }
\end{aligned}
$$

$\mathrm{CRMSE}=$ centered root mean square error

$\mathrm{MNB}=$ mean normalized bias

$\mathrm{MNE}=$ mean normalize error

$\mathrm{FB}=$ fractional bias

$\mathrm{FE}=$ fractional error

$r=$ Pearson correlation coefficient

$$
\begin{gathered}
\frac{1}{N} \sum\left(P_{j}-O_{j}\right) \\
\frac{1}{N} \sum\left|P_{j}-O_{j}\right| \\
\frac{\sum\left(P_{j}-O_{j}\right)}{\sum O_{j}} \times 100 \\
\frac{\sum\left|P_{j}-O_{j}\right|}{\sum O_{j}} \times 100 \\
\sqrt{\frac{1}{N} \sum\left(P_{j}-O_{j}\right)^{2}}
\end{gathered}
$$$$
\sqrt{\frac{1}{N} \sum\left[\left(P_{j}-\bar{P}\right)-\left(O_{j}-\bar{O}\right)\right]^{2}}
$$$$
\frac{1}{N} \sum \frac{\left(P_{j}-O_{j}\right)}{O_{j}} \times 100
$$$$
\frac{1}{N} \sum \frac{\left|P_{j}-O_{j}\right|}{O_{j}} \times 100
$$$$
\frac{2}{N} \sum \frac{\left(P_{j}-O_{j}\right)}{\left(P_{j}+O_{j}\right)} \times 100
$$$$
\frac{2}{N} \sum \frac{\left|P_{j}-O_{j}\right|}{\left(P_{j}+O_{j}\right)} \times 100
$$$$
\frac{\sum\left[\left(P_{j}-\bar{P}\right) \times\left(O_{j}-\bar{O}\right)\right]}{\sqrt{\sum\left(\left(P_{j}-\bar{P}\right)^{2} \times\left(O_{j}-\bar{O}\right)^{2}\right)}}
$$ 

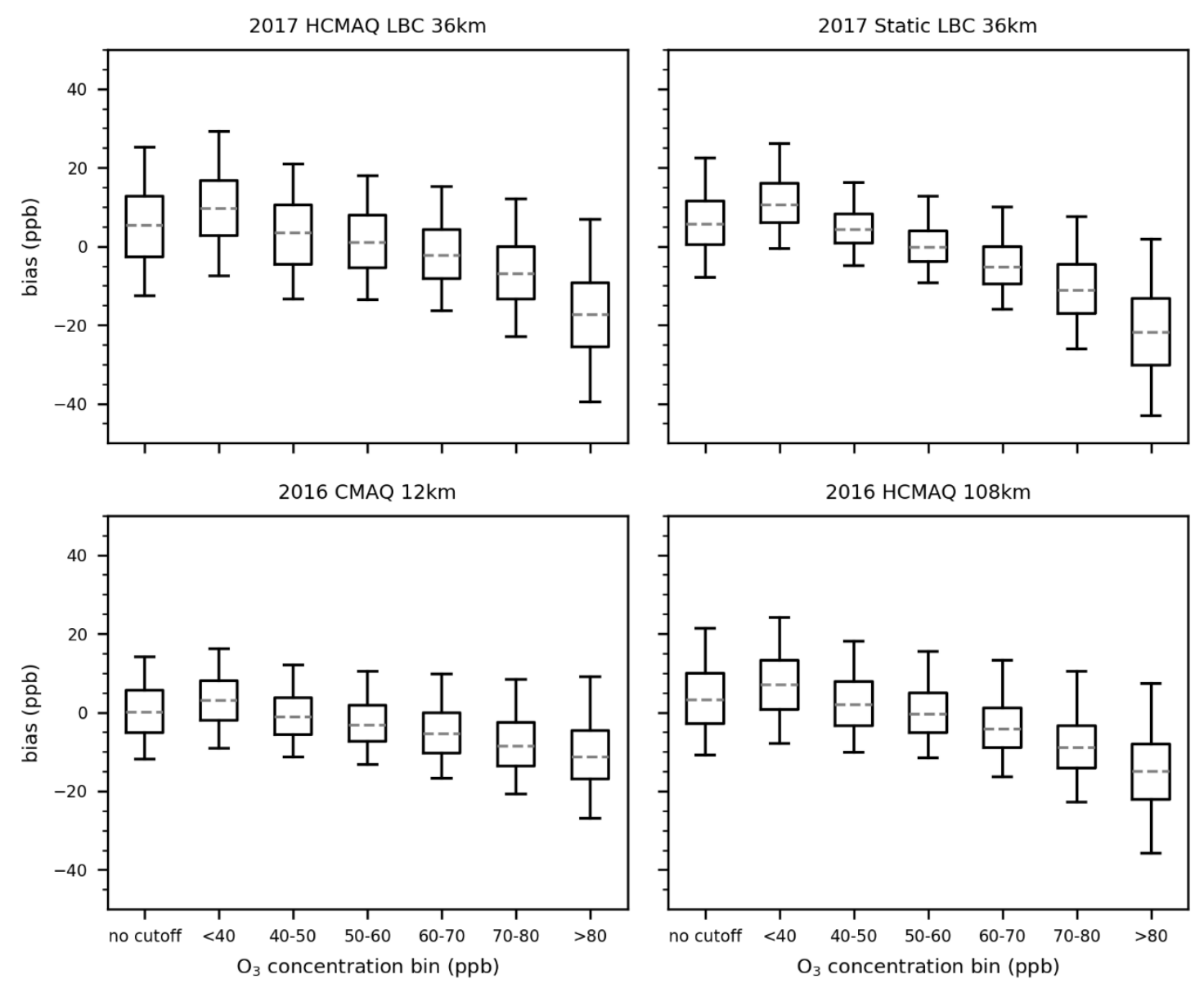

Figure S5. Boxplots showing the bias for several MDA8 $\mathrm{O}_{3}$ concentration bins for each simulation. Dashed grey lines show the median, boxes show the 25th and 75th percentiles, and whiskers extend to 1.5 times the interquartile range. 

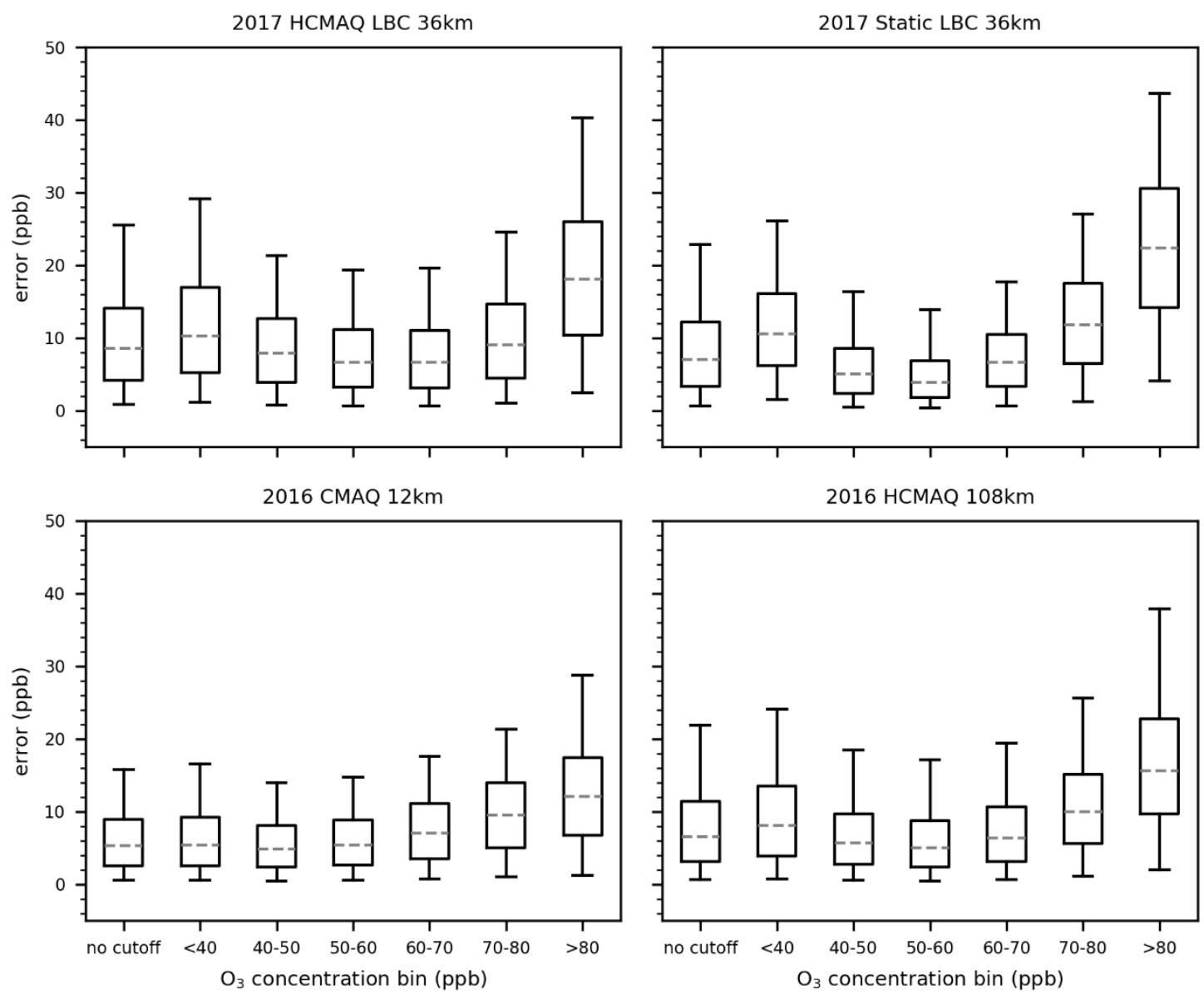

Figure S6. Boxplots showing the error for several MDA8 $\mathrm{O}_{3}$ concentration bins for each simulation. Dashed grey lines show the median, boxes show the 25 th and 75 th percentiles, and whiskers extend to 1.5 times the interquartile range.

Table S4. Bias and error metrics for several $\mathrm{MDA}_{8} \mathrm{O}_{3}$ concentration bins for each simulation. The model resolution for each case is shown in parentheses.

\begin{tabular}{|c|c|c|c|c|c|}
\hline $\begin{array}{c}\text { Performance } \\
\text { Metric }\end{array}$ & $\begin{array}{c}\text { MDA8 O }_{3} \\
\text { bin }\end{array}$ & $\begin{array}{c}2017 \\
\text { HCMAQ } \\
\text { LBC }(36 \mathrm{~km})\end{array}$ & $\begin{array}{c}\text { 2017 Static } \\
\text { LBC }(36 \mathrm{~km})\end{array}$ & $\begin{array}{c}2016 \text { fine } \\
\text { scale }(12 \mathrm{~km})\end{array}$ & $\begin{array}{c}2016 \text { coarse } \\
\text { scale }(108 \\
\mathrm{km})\end{array}$ \\
\hline $\mathrm{MB}(\mathrm{ppb})$ & no cutoff & 5.61 & 6.35 & 0.50 & 4.22 \\
\hline
\end{tabular}




\begin{tabular}{|c|c|c|c|c|c|}
\hline & $<40 \mathrm{ppb}$ & 10.12 & 11.49 & 3.23 & 7.56 \\
\hline & $40-50 \mathrm{ppb}$ & 3.38 & 4.95 & -0.57 & 3.00 \\
\hline & $50-60 \mathrm{ppb}$ & 1.64 & 0.67 & -2.48 & 0.90 \\
\hline & $60-70 \mathrm{ppb}$ & -1.39 & -4.19 & -4.74 & -2.73 \\
\hline & $70-80 \mathrm{ppb}$ & -6.17 & -10.17 & -7.63 & -7.42 \\
\hline & $>80 \mathrm{ppb}$ & -16.91 & -21.20 & -10.63 & -14.50 \\
\hline \multirow[t]{7}{*}{ ME (ppb) } & no cutoff & 10.26 & 8.82 & 6.39 & 8.53 \\
\hline & $<40 \mathrm{ppb}$ & 12.11 & 11.87 & 6.55 & 9.81 \\
\hline & $40-50 \mathrm{ppb}$ & 9.12 & 6.35 & 5.73 & 7.34 \\
\hline & $50-60 \mathrm{ppb}$ & 8.04 & 5.25 & 6.22 & 6.88 \\
\hline & $60-70 \mathrm{ppb}$ & 8.02 & 7.67 & 7.83 & 8.22 \\
\hline & $70-80 \mathrm{ppb}$ & 10.54 & 12.75 & 10.11 & 11.60 \\
\hline & $>80 \mathrm{ppb}$ & 19.25 & 22.95 & 13.25 & 17.26 \\
\hline \multirow[t]{7}{*}{ NMB (\%) } & no cutoff & 13.34 & 15.08 & 1.19 & 10.09 \\
\hline & $<40 \mathrm{ppb}$ & 32.03 & 36.38 & 10.22 & 23.89 \\
\hline & $40-50 \mathrm{ppb}$ & 7.55 & 11.07 & -1.28 & 6.72 \\
\hline & $50-60 \mathrm{ppb}$ & 3.03 & 1.23 & -4.58 & 1.65 \\
\hline & $60-70 \mathrm{ppb}$ & -2.18 & -6.55 & -7.41 & -4.27 \\
\hline & $70-80 \mathrm{ppb}$ & -8.35 & -13.76 & -10.32 & -10.04 \\
\hline & $>80 \mathrm{ppb}$ & -19.15 & -24.01 & -12.25 & -16.72 \\
\hline \multirow[t]{6}{*}{ NME (\%) } & no cutoff & 24.37 & 20.96 & 15.26 & 20.38 \\
\hline & $<40 \mathrm{ppb}$ & 38.31 & 37.58 & 20.72 & 31.01 \\
\hline & $40-50 \mathrm{ppb}$ & 20.37 & 14.18 & 12.83 & 16.44 \\
\hline & $50-60 \mathrm{ppb}$ & 14.82 & 9.68 & 11.47 & 12.67 \\
\hline & $60-70 \mathrm{ppb}$ & 12.55 & 12.01 & 12.25 & 12.85 \\
\hline & $70-80 \mathrm{ppb}$ & 14.26 & 17.25 & 13.68 & 15.69 \\
\hline
\end{tabular}




\begin{tabular}{|l|c|c|c|c|c|}
\hline & $>80 \mathrm{ppb}$ & 21.80 & 25.99 & 15.27 & 19.90 \\
\hline
\end{tabular}

Table S5. Performance metrics for $\mathrm{MDA}_{8} \mathrm{O}_{3}$ for each simulation. The model resolution for each case is shown in parentheses.

\begin{tabular}{|c|c|c|c|c|}
\hline Performance Metric & $\begin{array}{c}\text { 2017 HCMAQ } \\
\text { LBC (36km) }\end{array}$ & $\begin{array}{c}\text { 2017 Static } \\
\text { LBC }(36 \mathrm{~km})\end{array}$ & $\begin{array}{c}2016 \text { fine scale } \\
(12 \mathrm{~km})\end{array}$ & $\begin{array}{c}2016 \text { coarse } \\
\text { scale }(108 \mathrm{~km})\end{array}$ \\
\hline $\mathrm{N}$ & 380587 & 380587 & 366912 & 366912 \\
\hline Mean modeled (ppb) & 47.70 & 48.43 & 42.35 & 46.08 \\
\hline Mean observed (ppb) & 42.09 & 42.09 & 41.86 & 41.86 \\
\hline MB (ppb) & 5.61 & 6.35 & 0.50 & 4.22 \\
\hline ME (ppb) & 10.26 & 8.82 & 6.39 & 8.53 \\
\hline NMB (\%) & 13.34 & 15.08 & 1.19 & 10.09 \\
\hline NME (\%) & 24.37 & 20.96 & 15.26 & 20.38 \\
\hline RMSE (\%) & 13.30 & 11.80 & 8.18 & 12.24 \\
\hline CRMSE (\%) & 12.06 & 9.94 & 8.17 & 11.49 \\
\hline MNB (\%) & 19.23 & 21.77 & 4.27 & 14.71 \\
\hline MNE (\%) & 29.05 & 26.18 & 17.26 & 23.92 \\
\hline FB (\%) & 12.75 & 16.07 & 1.60 & 9.76 \\
\hline FE (\%) & 23.91 & 20.89 & 16.12 & 20.05 \\
\hline r & 0.54 & 0.60 & 0.76 & 0.59 \\
\hline
\end{tabular}


Table S6. Monthly breakdown of model performance for selected performance metrics (NMB, NME, r) for 2017 simulations.

\begin{tabular}{|c|c|c|c|c|c|c|c|}
\hline \multirow{2}{*}{ months } & \multirow{2}{*}{$\mathrm{N}$} & \multicolumn{2}{|c|}{2017 HCMAQ LBC (36km) } & \multicolumn{3}{|c|}{2017 Static LBC (36km) } \\
\cline { 3 - 8 } & & NMB & NME & $\mathrm{r}$ & NMB & NME & $\mathrm{r}$ \\
\hline Jan & 22914 & -10.71 & 21.02 & 0.48 & 16.34 & 21.45 & 0.60 \\
\hline Feb & 21666 & -9.88 & 19.24 & 0.42 & 12.19 & 17.42 & 0.50 \\
\hline Mar & 36607 & -8.03 & 18.98 & 0.31 & 11.47 & 15.65 & 0.47 \\
\hline Apr & 36455 & -1.23 & 16.69 & 0.44 & 6.59 & 13.83 & 0.60 \\
\hline May & 38274 & 3.71 & 16.15 & 0.53 & 6.51 & 14.63 & 0.60 \\
\hline Jun & 36831 & 15.13 & 22.04 & 0.58 & 13.43 & 21.67 & 0.56 \\
\hline Jul & 37473 & 29.94 & 33.31 & 0.49 & 19.54 & 26.92 & 0.43 \\
\hline Aug & 37063 & 32.59 & 35.09 & 0.52 & 20.78 & 26.77 & 0.44 \\
\hline Sep & 34511 & 26.36 & 28.40 & 0.66 & 16.72 & 22.34 & 0.59 \\
\hline Oct & 34623 & 27.72 & 29.42 & 0.69 & 21.52 & 24.47 & 0.67 \\
\hline Nov & 22100 & 25.52 & 27.57 & 0.59 & 25.36 & 26.93 & 0.60 \\
\hline Dec & 22070 & 19.11 & 23.74 & 0.58 & 21.12 & 24.46 & 0.57 \\
\hline total & 380587 & 13.34 & 24.37 & 0.54 & 15.08 & 20.96 & 0.60 \\
\hline
\end{tabular}

Table S7. Monthly breakdown of model performance for selected performance metrics (NMB, NME, r) for 2016 simulations.

\begin{tabular}{|c|c|c|c|c|c|c|c|}
\hline \multirow{2}{*}{ months } & \multirow{2}{*}{$\mathrm{N}$} & \multicolumn{3}{|c|}{2016 fine scale $(12 \mathrm{~km})$} & \multicolumn{3}{c|}{2016 coarse scale $(108 \mathrm{~km})$} \\
\cline { 3 - 8 } & & NMB & NME & $\mathrm{r}$ & NMB & NME & $\mathrm{r}$ \\
\hline Jan & 22385 & -12.44 & 18.13 & 0.61 & -5.90 & 18.69 & 0.41 \\
\hline Feb & 21525 & -11.89 & 15.77 & 0.68 & -5.69 & 15.14 & 0.58 \\
\hline Mar & 26841 & -6.62 & 12.42 & 0.71 & -0.58 & 12.97 & 0.54 \\
\hline
\end{tabular}




\begin{tabular}{|c|c|c|c|c|c|c|c|}
\hline Apr & 35298 & -7.00 & 13.45 & 0.69 & -0.38 & 13.97 & 0.52 \\
\hline May & 37492 & -3.79 & 13.79 & 0.70 & 4.98 & 17.10 & 0.44 \\
\hline Jun & 35994 & 0.07 & 13.46 & 0.76 & 9.12 & 19.34 & 0.45 \\
\hline Jul & 37511 & 9.43 & 16.75 & 0.77 & 20.72 & 26.04 & 0.53 \\
\hline Aug & 37578 & 13.71 & 18.79 & 0.80 & 26.32 & 29.51 & 0.61 \\
\hline Sep & 36042 & 12.06 & 16.26 & 0.81 & 23.00 & 26.07 & 0.64 \\
\hline Oct & 32963 & 8.98 & 14.12 & 0.79 & 17.66 & 20.73 & 0.71 \\
\hline Nov & 21734 & 1.14 & 13.18 & 0.72 & 10.06 & 17.62 & 0.60 \\
\hline Dec & 21549 & -6.55 & 19.45 & 0.53 & -0.02 & 22.99 & 0.33 \\
\hline total & 366912 & 1.19 & 15.26 & 0.76 & 10.09 & 20.38 & 0.59 \\
\hline
\end{tabular}




\section{Lateral Boundary Condition Effects on 2017 CTM Results}

The simulated base case and US- $\mathrm{B} \mathrm{O}_{3}$ at observation locations can vary significantly between the two 2017 LBC cases; however, the US-A O 3 is typically very consistent. We find that the differences in US-B $\mathrm{O}_{3}$ between the two LBC cases correlate very strongly with the differences in base case $\mathrm{O}_{3}\left(\mathrm{R}^{2}=0.98\right)$ (Figure $\mathrm{S} 7$ left) while the differences in US-A O $\mathrm{O}_{3}$ are less strongly related to differences in the base case $\mathrm{O}_{3}\left(\mathrm{R}^{2}=0.33\right)$ (Figure $\mathrm{S} 7$ right). This indicates that the differences in the simulated base case $\mathrm{O}_{3}$ are being driven primarily by the differences in the simulated US-B $\mathrm{O}_{3}$ (which is caused by the differences in LBCs) and are not affected much by differences in the simulated US-A $\mathrm{O}_{3}$. While there are interactions between species originating from US-B and US-A sources, we find that the effect on US-A $\mathrm{O}_{3}$ is usually small. We conclude from this that the different estimates of US- $\mathrm{B} \mathrm{O}_{3}$ in the 2017 simulations do not significantly affect the chemistry of local $\mathrm{O}_{3}$ formation from US-A emissions or the ozone production efficiency.
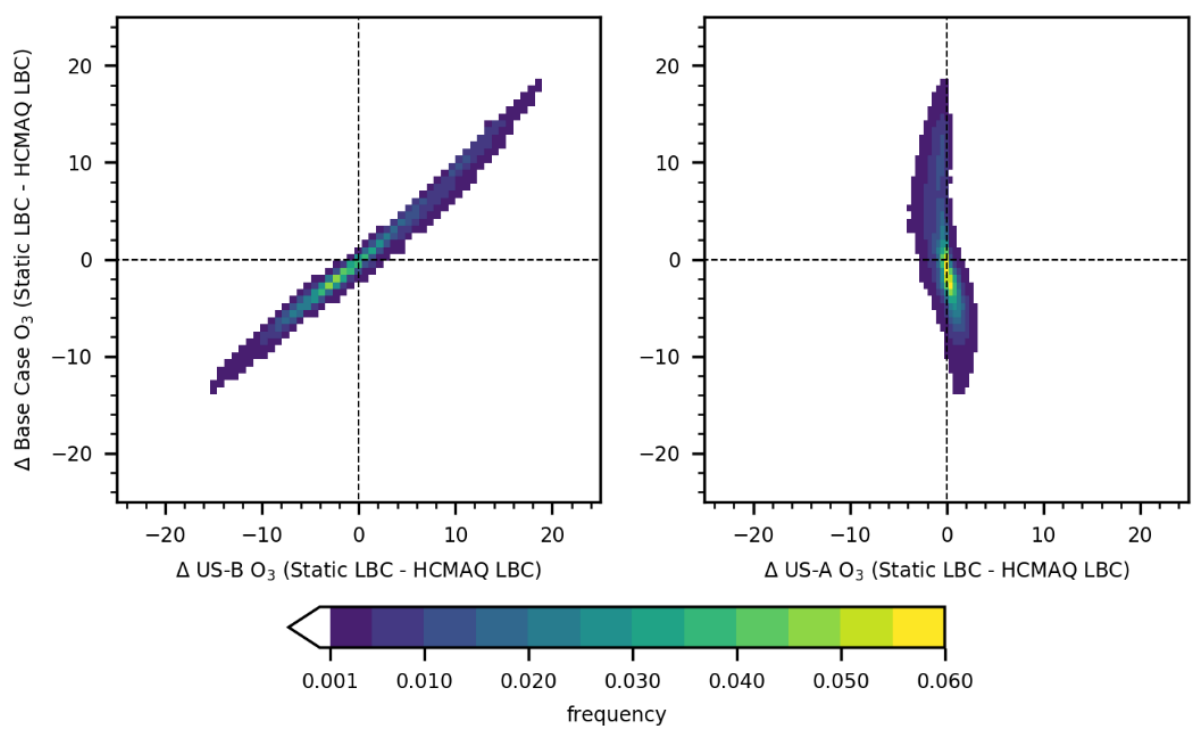
Figure S7. LBC-driven differences in 2017 simulated base case MDA8 $\mathrm{O}_{3}$ compared to differences in simulated US-B (left) and US-A MDA8 $\mathrm{O}_{3}$ (right). Comparisons are shown for dates and locations with valid observations. 


\section{Ozone Regression Model Without Meteorological Variables}

Table S8. Coefficients and $\mathrm{R}^{2}$ obtained by ozone regression model in Equation 1 (which does not include meteorological variables) for each simulation. The model resolution of each CTM simulation is given in parentheses.

\begin{tabular}{|c|c|c|c|c|}
\hline & $\begin{array}{c}\text { 2017 HCMAQ } \\
\text { LBC }(36 \mathrm{~km})\end{array}$ & $\begin{array}{c}2017 \text { Static LBC } \\
(36 \mathrm{~km})\end{array}$ & $\begin{array}{c}2016 \text { fine scale }(12 \\
\mathrm{km})\end{array}$ & $\begin{array}{c}2016 \text { coarse scale } \\
(108 \mathrm{~km})\end{array}$ \\
\hline$\alpha_{0, \text { US-B }}$ & 0.94 & 0.88 & 1.05 & 1.06 \\
\hline$\alpha_{0, \text { US-A }}$ & 0.80 & 0.90 & 0.86 & 0.67 \\
\hline$\alpha_{\text {X,US-B }}$ & 0.013 & -0.012 & -0.0081 & -0.021 \\
\hline$\alpha_{\text {X,US-A }}$ & 0.091 & 0.12 & 0.051 & 0.028 \\
\hline$\alpha_{\text {Y,US-B }}$ & 0.055 & 0.020 & 0.022 & 0.010 \\
\hline$\alpha_{\text {Y,US-A }}$ & -0.061 & -0.025 & -0.0065 & -0.0049 \\
\hline$\alpha_{\text {Z,US-B }}$ & -0.013 & -0.0027 & 0.0042 & -0.023 \\
\hline$\alpha_{\text {Z,US-A }}$ & 0.14 & 0.16 & 0.043 & 0.19 \\
\hline$\alpha_{\text {sin,US-B }}$ & 0.19 & 0.059 & 0.078 & 0.089 \\
\hline$\alpha_{\text {sin,US-A }}$ & -0.10 & -0.012 & 0.024 & -0.016 \\
\hline$\alpha_{\text {cos,US-B }}$ & 0.042 & -0.028 & 0.027 & -0.017 \\
\hline$\alpha_{\text {cos,US-A }}$ & 0.051 & 0.052 & 0.0059 & 0.076 \\
\hline$R^{2}$ & 0.45 & 0.46 & 0.65 & 0.48 \\
\hline
\end{tabular}


Table S9. Performance metrics for adjusted $\mathrm{MDA}_{8} \mathrm{O}_{3}$ for each simulation. The model resolution for each case is shown in parentheses. These results are for the regression models that do not include adjustments for meteorological variables.

\begin{tabular}{|c|c|c|c|c|}
\hline Performance Metric & $\begin{array}{c}\text { Adjusted 2017 } \\
\text { HCMAQ LBC } \\
(36 \mathrm{~km})\end{array}$ & $\begin{array}{c}\text { Adjusted 2017 } \\
\text { Static LBC } \\
(36 \mathrm{~km})\end{array}$ & $\begin{array}{c}\text { Adjusted 2016 } \\
\text { CMAQ (12km) }\end{array}$ & $\begin{array}{c}\text { Adjusted 2016 } \\
\text { HCMAQ } \\
(108 \mathrm{~km})\end{array}$ \\
\hline $\mathrm{N}$ & 380587 & 380587 & 366912 & 366912 \\
\hline Mean modeled (ppb) & 41.81 & 41.90 & 41.77 & 41.59 \\
\hline Mean observed (ppb) & 42.09 & 42.09 & 41.86 & 41.86 \\
\hline MB (ppb) & -0.28 & -0.18 & -0.09 & -0.27 \\
\hline ME (ppb) & 6.80 & 6.66 & 5.37 & 6.48 \\
\hline NMB (\%) & -0.66 & -0.44 & -0.22 & -0.64 \\
\hline NME (\%) & 16.15 & 15.83 & 12.83 & 15.47 \\
\hline RMSE (\%) & 8.90 & 8.85 & 7.05 & 8.69 \\
\hline CRMSE (\%) & 8.90 & 8.85 & 7.05 & 8.69 \\
\hline MNB (\%) & 4.21 & 4.60 & 3.11 & 3.82 \\
\hline MNE (\%) & 18.47 & 18.12 & 14.50 & 17.34 \\
\hline FB (\%) & 1.08 & 1.53 & 1.05 & 0.99 \\
\hline FE (\%) & 16.91 & 16.49 & 13.55 & 16.03 \\
\hline r & 0.68 & 0.68 & 0.81 & 0.70 \\
\hline
\end{tabular}




\section{Ozone Regression Model with Meteorological Variables}

The regression model formulation which included meteorological variables (temperature anomaly, relative humidity, and cloud cover) is shown by Equation S1. Table S6 shows the coefficients obtained from this model for each simulation case. Table S7 shows the values for the US- $\mathrm{B} \mathrm{O}_{3}$ convergence metric for the simulated (i.e. unadjusted) results and for the adjusted results using the regressions both with and without meteorological variable adjustment.

$\left[O_{3}\right]_{\text {observed }}=\alpha_{U S-B}(s, t, m) *\left[O_{3}\right]_{U S-B}^{\operatorname{sim}}+\alpha_{U S-A}(s, t, m) *\left[O_{3}\right]_{U S-A}^{s i m}$

Where:

$$
\begin{aligned}
\alpha_{U S-B}(s, t, m) & =\alpha_{0, U S-B}+\alpha_{X, U S-B} * X+\alpha_{Y, U S-B} * Y+\alpha_{Z, U S-B} * Z \\
& +\alpha_{s i n, U S-B} \sin \left(\frac{2 \pi}{365} d\right)+\alpha_{\cos , U S-B} \cos \left(\frac{2 \pi}{365} d\right) \\
& +\alpha_{\Delta T, U S-B} * \Delta T+\alpha_{R H, U S-B} * R H+\alpha_{C L D, U S-B} * C L D \\
\alpha_{U S-A}(s, t, m) & =\alpha_{0, U S-A}+\alpha_{X, U S-A} * X+\alpha_{Y, U S-A} * Y+\alpha_{Z, U S-A} * Z \\
& +\alpha_{s i n, U S-A} \sin \left(\frac{2 \pi}{365} d\right)+\alpha_{\cos , U S-A} \cos \left(\frac{2 \pi}{365} d\right) \\
& +\alpha_{\Delta T, U S-A} * \Delta T+\alpha_{R H, U S-A} * R H+\alpha_{C L D, U S-A} * C L D
\end{aligned}
$$

The variables $(s, t, m)$ signify that the values vary with space, time, and meteorology. Each of the following variables are normalized to zero mean and unit variance:

$\mathrm{X}=$ longitude

$\mathrm{Y}=$ latitude

$\mathrm{Z}=$ elevation

$\mathrm{d}=$ day of year

$\Delta \mathrm{T}=$ deviation of daily mean temperature from annual mean 
$\mathrm{RH}=$ relative humidity

CLD = cloud cover (i.e. fraction of model grid cell covered by clouds)

Table S10. Coefficients obtained by ozone regression model for each simulation for ozone regression model that includes meteorological variables. The model resolution of each CTM simulation is given in parentheses.

\begin{tabular}{|c|c|c|}
\hline & 2017 HCMAQ LBC (36 km) & 2017 Static LBC $(36 \mathrm{~km})$ \\
\hline$\alpha_{0, \text { US-B }}$ & 0.94 & 0.88 \\
\hline$\alpha_{0, \text { US-A }}$ & 0.76 & 0.81 \\
\hline$\alpha \mathrm{X}, \mathrm{US}-\mathrm{B}$ & -0.010 & -0.026 \\
\hline$\alpha \mathrm{X}, \mathrm{US}-\mathrm{A}$ & 0.020 & 0.048 \\
\hline$\alpha_{Y, U S-B}$ & 0.061 & 0.027 \\
\hline$\alpha_{\mathrm{Y}, \mathrm{US}-\mathrm{A}}$ & -0.062 & -0.055 \\
\hline$\alpha_{Z, U S-B}$ & -0.018 & -0.0057 \\
\hline$\alpha$ Z,US-A & 0.10 & 0.11 \\
\hline$\alpha_{\mathrm{sin}, \mathrm{US}-\mathrm{B}}$ & 0.18 & 0.063 \\
\hline$\alpha_{\text {sin,US-A }}$ & -0.11 & -0.0045 \\
\hline$\alpha_{\mathrm{cos}, \mathrm{US}-\mathrm{B}}$ & 0.023 & -0.029 \\
\hline$\alpha_{\cos , \mathrm{US}-\mathrm{A}}$ & 0.078 & 0.12 \\
\hline$\alpha_{\Delta \mathrm{T}, \mathrm{US}-\mathrm{B}}$ & -0.020 & 0.0037 \\
\hline$\alpha_{\Delta \mathrm{T}, \mathrm{US}-\mathrm{A}}$ & 0.013 & 0.10 \\
\hline$\alpha_{\mathrm{RH}, \mathrm{US}-\mathrm{B}}$ & -0.015 & -0.014 \\
\hline$\alpha_{\text {RH,US-A }}$ & -0.11 & -0.11 \\
\hline$\alpha_{\text {CLD,US-B }}$ & -0.024 & -0.021 \\
\hline$\alpha_{C L D, U S-A}$ & -0.13 & -0.12 \\
\hline
\end{tabular}




\begin{tabular}{|l|l|l|}
\hline $\mathrm{R}^{2}$ & 0.53 & 0.53 \\
\hline
\end{tabular}

Table S11. Values of US-B O 3 convergence metric for the simulated (i.e. unadjusted) 2017 results and for the adjusted results using the regressions both with and without meteorological variable adjustment. Also shown for the adjusted results is the percent change from the unadjusted result.

\begin{tabular}{|c|c|c|c|}
\hline & $\begin{array}{c}\text { Simulated (i.e. } \\
\text { unadjusted) }\end{array}$ & $\begin{array}{c}\text { Without } \\
\text { meteorological } \\
\text { adjustment }\end{array}$ & $\begin{array}{c}\text { With } \\
\text { meteorological } \\
\text { adjustment }\end{array}$ \\
\hline convergence metric (ppb) & 8.0 & 5.8 & 5.5 \\
\hline change from unadjusted (\%) & $\mathrm{n} / \mathrm{a}$ & -27.6 & -31.7 \\
\hline
\end{tabular}




\section{Regression Model Cross-Validation Results}

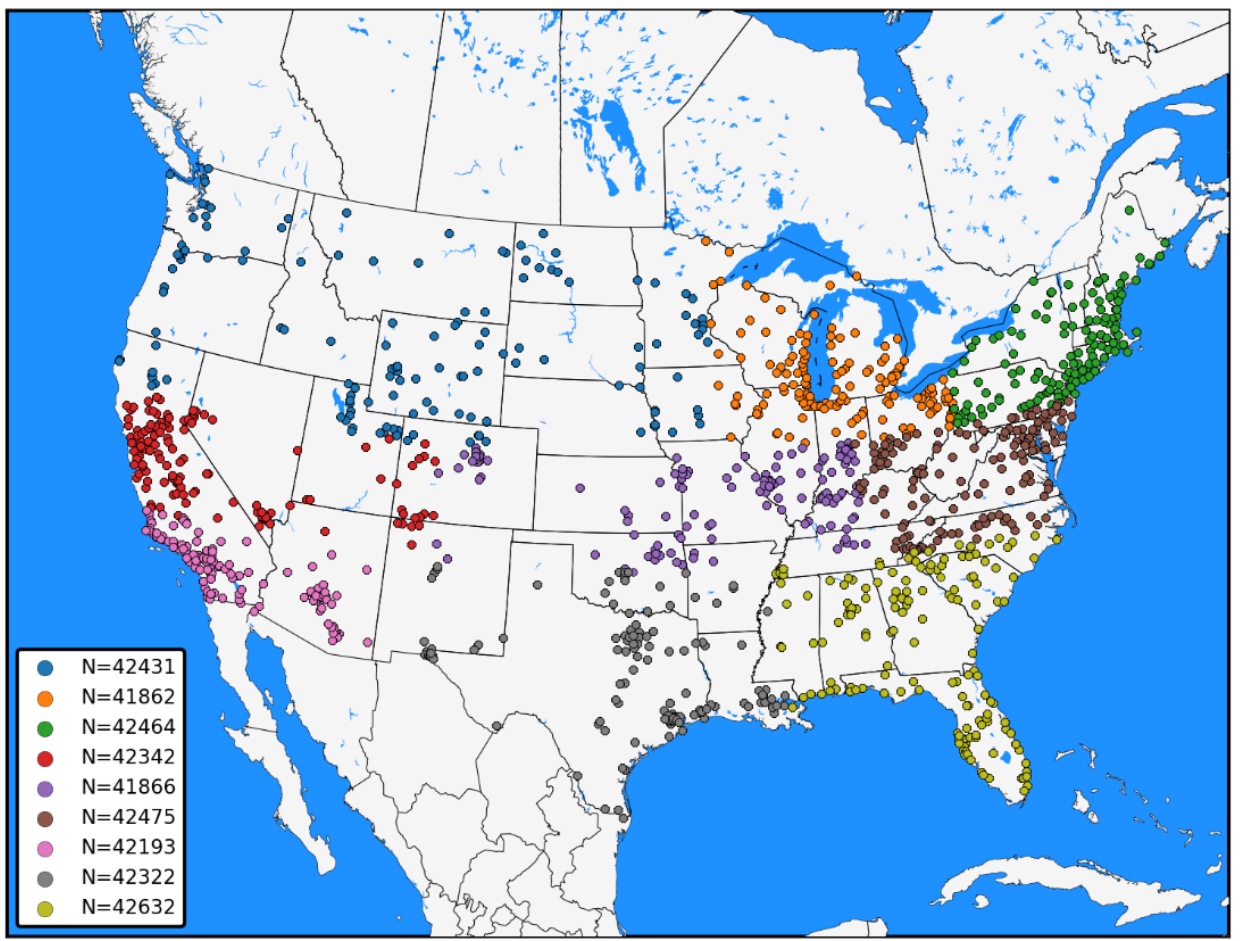

Figure S8. Grouping of monitoring site locations for the 2017 spatial cross-validation. The legend describes the number of datapoints for the year for each grouping. 


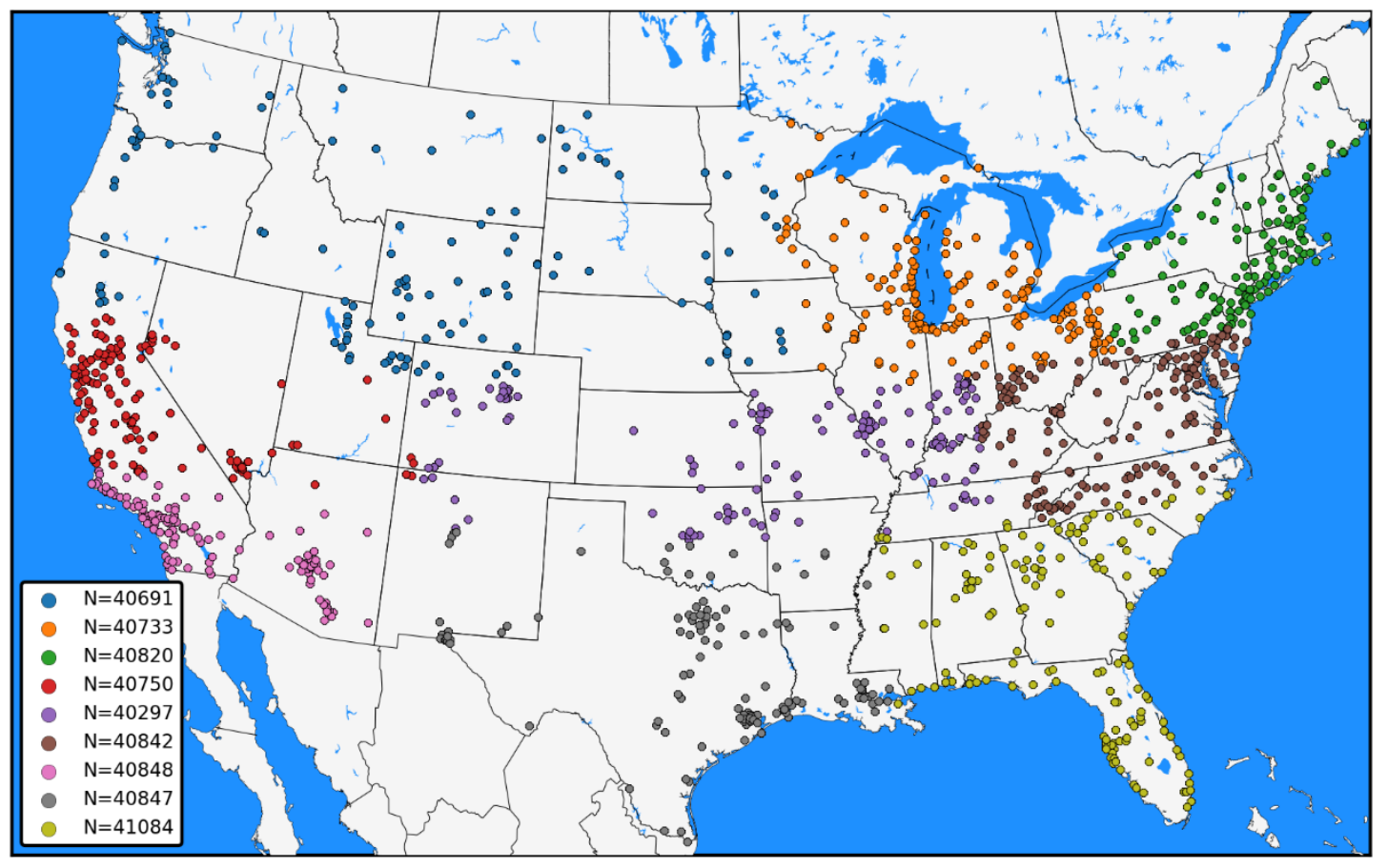

Figure S9. Grouping of monitoring site locations for the 2016 spatial cross-validation. The legend describes the number of datapoints for the year for each grouping. 
Table S12. $\mathrm{R}^{2}$ scores for tenfold cross-validation with random data withholding for 2017 LBC cases using regression models both with and without meteorological variables included in the regression model. The mean $\mathrm{R}^{2}$ from the cross-validation are provided with $95 \%$ confidence intervals in parentheses. The $\mathrm{R}^{2}$ of the model using the full dataset is also provided along with the difference between the mean cross-validation $\mathrm{R}^{2}$ and the full dataset $\mathrm{R}^{2}$.

\begin{tabular}{|c|c|c|c|c|}
\hline & $\begin{array}{c}\text { 2017 HCMAQ } \\
\text { LBC (36 km) } \\
\text { without } \\
\text { meteorological } \\
\text { adjustment }\end{array}$ & $\begin{array}{c}\text { 2017 Static LBC } \\
\text { (36 km) without } \\
\text { meteorological } \\
\text { adjustment }\end{array}$ & $\begin{array}{c}\text { 2017 HCMAQ } \\
\text { LBC (36 km) } \\
\text { with } \\
\text { meteorological } \\
\text { adjustment }\end{array}$ & $\begin{array}{c}\text { 2017 Static LBC } \\
\text { (36 km) with } \\
\text { meteorological } \\
\text { adjustment }\end{array}$ \\
\hline 1 & 0.45 & 0.45 & 0.52 & 0.54 \\
\hline 2 & 0.44 & 0.45 & 0.53 & 0.54 \\
\hline 3 & 0.45 & 0.46 & 0.53 & 0.54 \\
\hline 4 & 0.46 & 0.45 & 0.53 & 0.54 \\
\hline 5 & 0.45 & 0.45 & 0.53 & 0.53 \\
\hline 6 & 0.45 & 0.46 & 0.52 & 0.53 \\
\hline 7 & 0.45 & 0.45 & 0.53 & 0.53 \\
\hline 8 & 0.45 & 0.45 & 0.52 & 0.53 \\
\hline 9 & 0.44 & 0.46 & 0.53 & 0.52 \\
\hline 10 & 0.45 & 0.46 & 0.53 & 0.53 \\
\hline mean $\mathrm{R}^{2}$ & $0.45( \pm 0.01)$ & $0.46( \pm 0.01)$ & $0.53( \pm 0.01)$ & $0.53( \pm 0.01)$ \\
\hline full data $\mathrm{R}^{2}$ & $-1.1 \mathrm{E}-04$ & $-1.0 \mathrm{E}-04$ & $-1.3 \mathrm{E}-04$ & $-1.9 \mathrm{E}-04$ \\
\hline change in $\mathrm{R}^{2}$ & & & & \\
\hline
\end{tabular}


Table S13. $\mathrm{R}^{2}$ scores for cross-validation with spatial data withholding for $2017 \mathrm{LBC}$ cases using regression models both with and without meteorological variables included in the regression model. The mean $\mathrm{R}^{2}$ from the cross-validation are provided with $95 \%$ confidence intervals in parentheses. The $\mathrm{R}^{2}$ of the model using the full dataset is also provided along with the difference between the mean cross-validation $\mathrm{R}^{2}$ and the full dataset $\mathrm{R}^{2}$. The leftmost column provides the region of the US where the monitors are located which correspond to the areas of the country in Figure S5.

\begin{tabular}{|c|c|c|c|c|}
\hline & $\begin{array}{c}\text { 2017 HCMAQ } \\
\text { LBC (36 km) } \\
\text { without } \\
\text { meteorological } \\
\text { adjustment }\end{array}$ & $\begin{array}{c}\text { 2017 Static LBC } \\
\text { (36 km) without } \\
\text { meteorological } \\
\text { adjustment }\end{array}$ & $\begin{array}{c}\text { 2017 HCMAQ } \\
\text { LBC (36 km) } \\
\text { with } \\
\text { meteorological } \\
\text { adjustment }\end{array}$ & $\begin{array}{c}\text { 2017 Static LBC } \\
\text { (36 km) with } \\
\text { meteorological } \\
\text { adjustment }\end{array}$ \\
\hline Northwest & 0.35 & 0.38 & 0.42 & 0.46 \\
\hline North central & 0.47 & 0.51 & 0.58 & 0.61 \\
\hline Northeast & 0.24 & 0.34 & 0.38 & 0.43 \\
\hline Center west & 0.47 & 0.44 & 0.48 & 0.48 \\
\hline Center central & 0.45 & 0.48 & 0.58 & 0.59 \\
\hline Center east & 0.36 & 0.40 & 0.54 & 0.54 \\
\hline Southwest & 0.31 & 0.31 & 0.27 & 0.29 \\
\hline South central & 0.48 & 0.54 & 0.58 & 0.62 \\
\hline Southeast & 0.13 & 0.02 & 0.32 & 0.23 \\
\hline mean $\mathrm{R}^{2}$ & $0.36( \pm 0.23)$ & $0.38( \pm 0.29)$ & $0.46( \pm 0.22)$ & $0.47( \pm 0.26)$ \\
\hline full data $\mathrm{R}^{2}$ & 0.45 & 0.46 & 0.53 & 0.53 \\
\hline change in $\mathrm{R}^{2}$ & -0.09 & -0.08 & -0.07 & -0.06 \\
\hline
\end{tabular}


Table S14. $\mathrm{R}^{2}$ scores for tenfold cross-validation with random data withholding for 2016 cases. Only results without meteorological variables included in the regression model are shown. The mean $\mathrm{R}^{2}$ from the cross-validation are provided with $95 \%$ confidence intervals in parentheses. The $\mathrm{R}^{2}$ of the model using the full dataset is also provided along with the difference between the mean cross-validation $\mathrm{R}^{2}$ and the full dataset $\mathrm{R}^{2}$.

\begin{tabular}{|c|c|c|}
\hline & 2016 fine scale $(12 \mathrm{~km})$ & 2016 coarse scale $(108 \mathrm{~km})$ \\
\hline 1 & 0.65 & 0.48 \\
\hline 2 & 0.65 & 0.48 \\
\hline 4 & 0.65 & 0.49 \\
\hline 5 & 0.66 & 0.47 \\
\hline 6 & 0.65 & 0.47 \\
\hline 7 & 0.65 & 0.48 \\
\hline 8 & 0.65 & 0.47 \\
\hline 9 & 0.65 & 0.47 \\
\hline 10 & 0.66 & 0.47 \\
\hline mean $\mathrm{R}^{2}$ & 0.66 & 0.46 \\
\hline full data $\mathrm{R}^{2}$ & $0.65( \pm 0.01)$ & $0.47( \pm 0.01)$ \\
\hline change in $\mathrm{R}^{2}$ & 0.65 & 0.47 \\
\hline
\end{tabular}


Table S15. $\mathrm{R}^{2}$ scores for cross-validation with spatial data withholding for 2016 cases. Only results without meteorological variables included in the regression model are shown. The mean $\mathrm{R}^{2}$ from the cross-validation are provided with $95 \%$ confidence intervals in parentheses. The $\mathrm{R}^{2}$ of the model using the full dataset is also provided along with the difference between the mean crossvalidation $R^{2}$ and the full dataset $R^{2}$. The leftmost column provides the region of the US where the monitors are located which correspond to the areas of the country in Figure S6.

\begin{tabular}{|c|c|c|}
\hline & 2016 fine scale $(12 \mathrm{~km})$ & 2016 coarse scale $(108 \mathrm{~km})$ \\
\hline Northwest & 0.50 & 0.39 \\
\hline North central & 0.65 & 0.37 \\
\hline Northeast & 0.61 & 0.39 \\
\hline Center west & 0.67 & 0.46 \\
\hline Center central & 0.63 & 0.51 \\
\hline Center East & 0.66 & 0.49 \\
\hline Southwest & 0.62 & 0.45 \\
\hline South central & 0.53 & 0.33 \\
\hline Southeast & 0.65 & 0.09 \\
\hline mean $\mathrm{R}^{2}$ & $0.62( \pm 0.11)$ & $0.39( \pm 0.24)$ \\
\hline full data $\mathrm{R}^{2}$ & 0.65 & 0.47 \\
\hline change in $\mathrm{R}^{2}$ & -0.04 & -0.09 \\
\hline
\end{tabular}




\section{Seasonal Average Ozone Adjustment Factors}
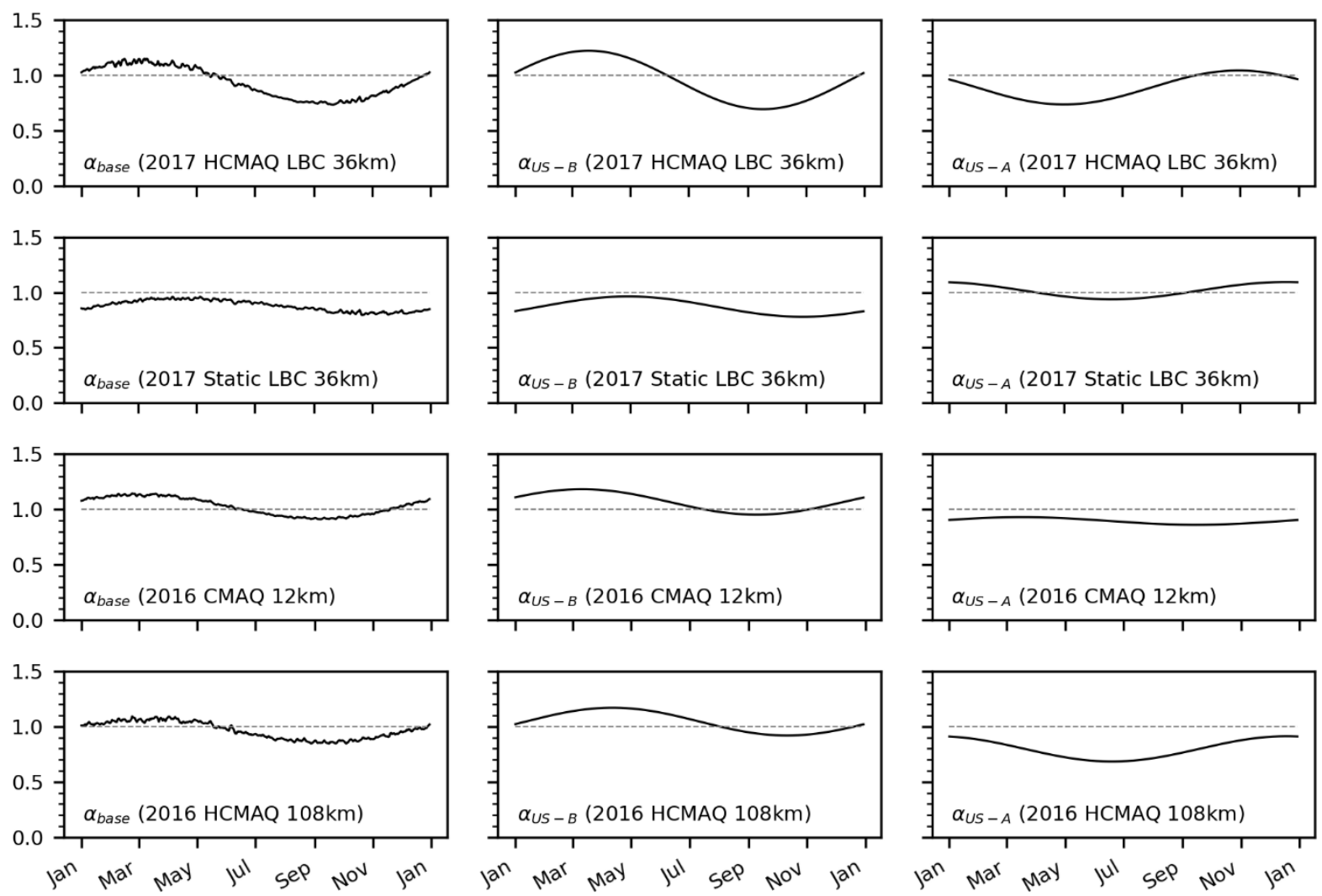

Figure S10. Adjustment factors $(\alpha)$ for base case, US-B, and US-A $\mathrm{O}_{3}$ for each simulation. The values are the daily average of all model grid cells over the contiguous US. $\alpha>1$ indicates adjusted $\mathrm{O}_{3}>$ CMAQ-simulated $\mathrm{O}_{3}$, i.e., CMAQ results are biased low. 
Annual Mean $\alpha$ Values
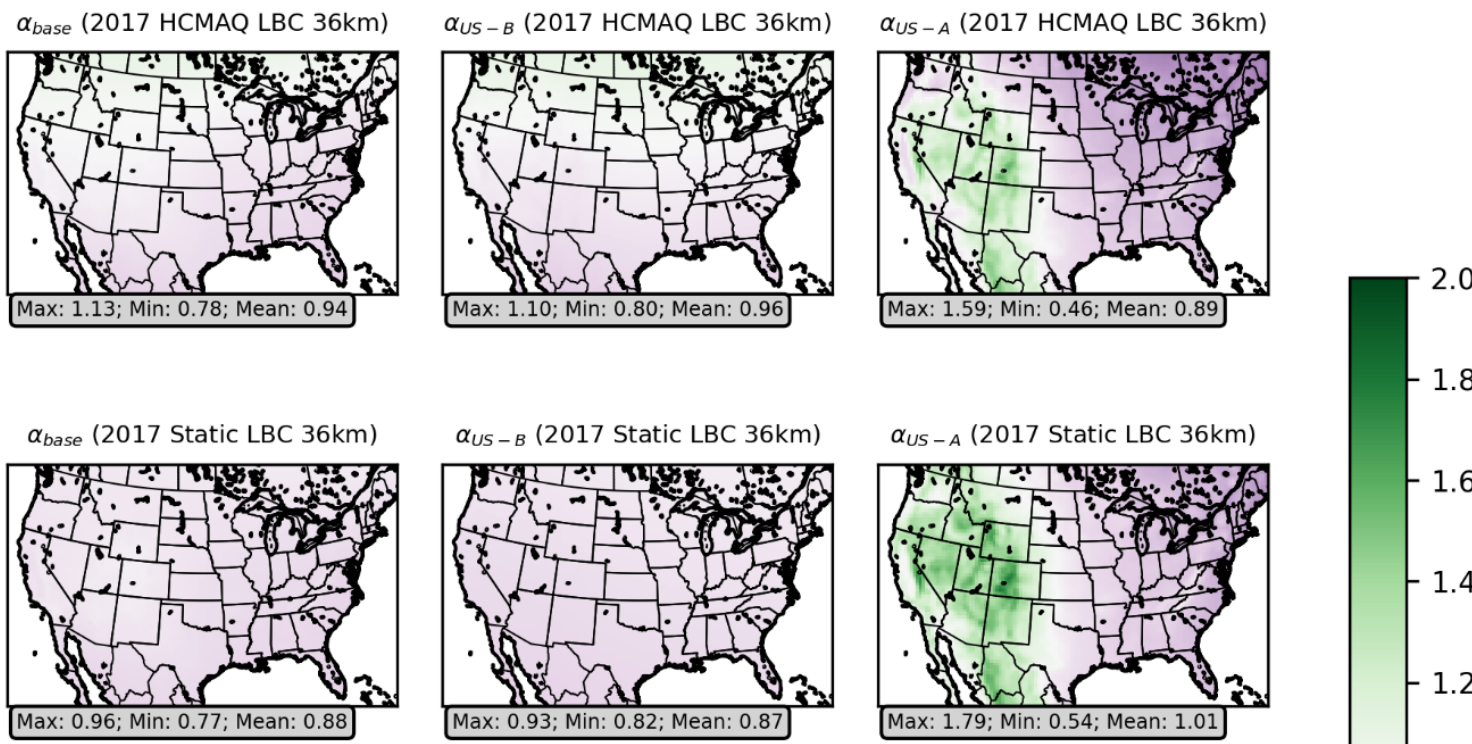

1.8

1.6

1.4

1.2

1.0

$\alpha_{\text {base }}(2016$ CMAQ $12 \mathrm{~km}$ )

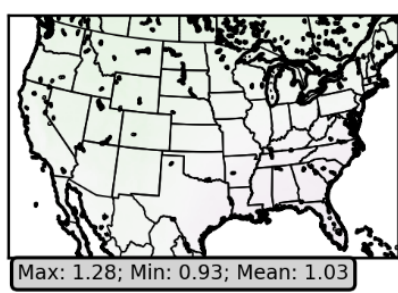

$\alpha_{U S-B}(2016$ CMAQ $12 \mathrm{~km})$
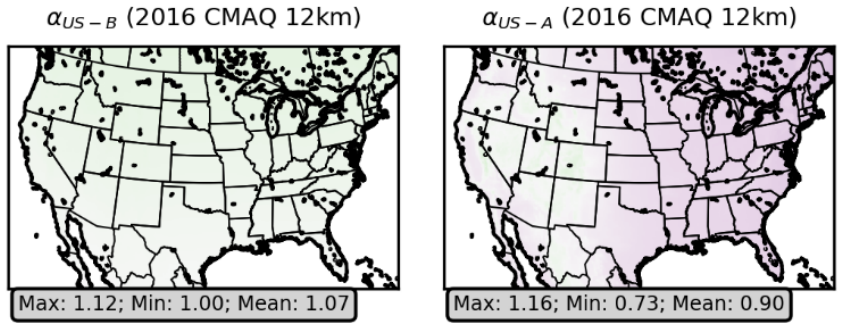

0.6

$-0.4$

0.2
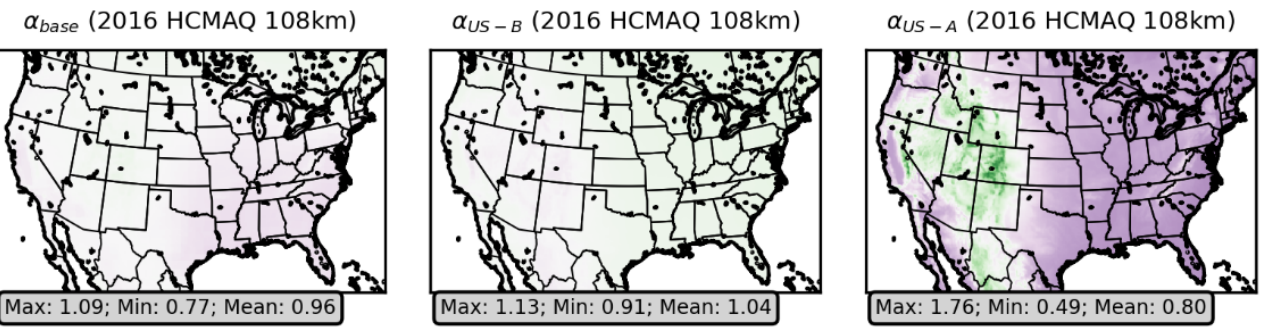

Figure S11. Annual average of $\mathrm{O}_{3}$ adjustment ratios for all cases. Max, min, and mean refer to the maximum, minimum, and mean values over the contiguous US. $\left.\alpha=\left[\mathrm{O}_{3}\right]^{\text {simulated } /\left[\mathrm{O}_{3}\right.}\right]^{\text {adjusted }}$. 
Winter (DJF) Mean $\alpha$ Values
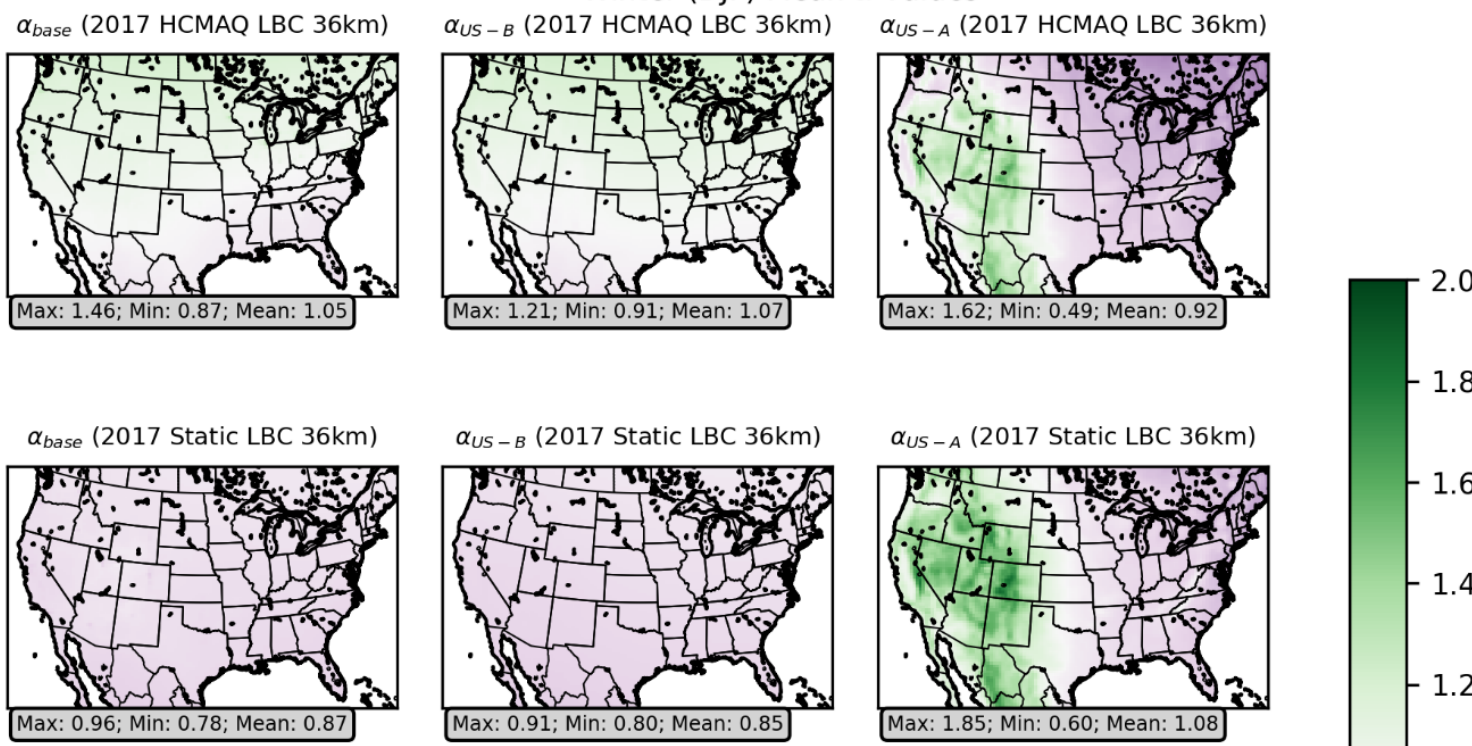

1.8

$-1.6$

1.4

1.2

1.0

$\alpha_{\text {base }}(2016$ CMAQ $12 \mathrm{~km}$ )

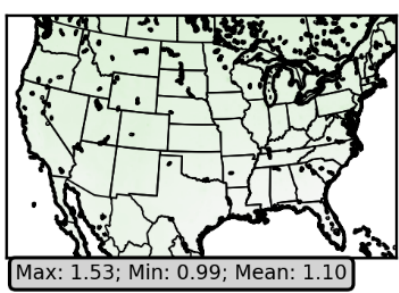

$\alpha_{U S-B}$ (2016 CMAQ 12km)
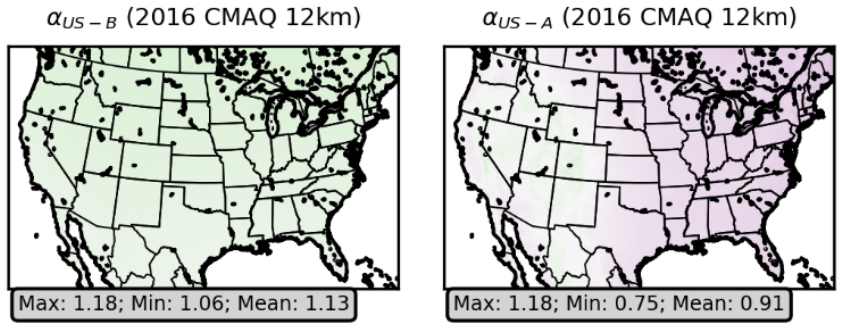

0.6

0.4

$-0.2$
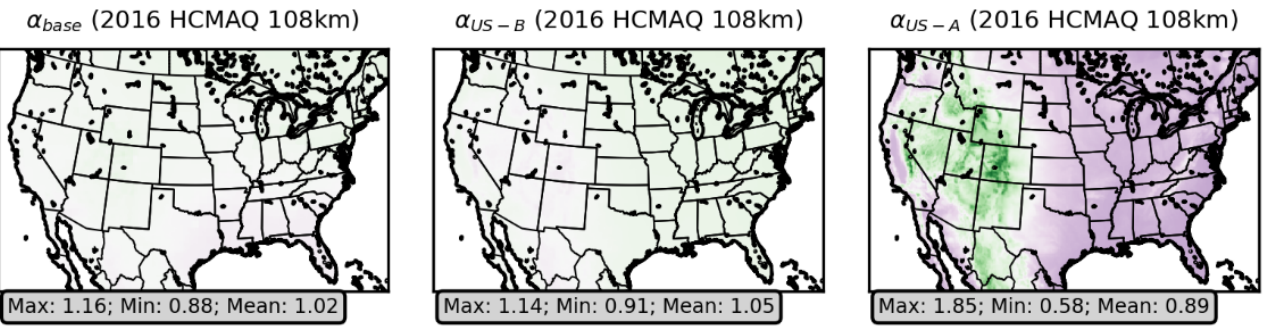

Figure S12. Winter (December, January, February) average of $\mathrm{O}_{3}$ adjustment ratios for all cases. Max, min, and mean refer to the maximum, minimum, and mean values over the contiguous US. $\alpha=\left[\mathrm{O}_{3}\right]^{\text {simulated }} /\left[\mathrm{O}_{3}\right]^{\text {adjusted }}$. 
Spring (MAM) Mean $\alpha$ Values
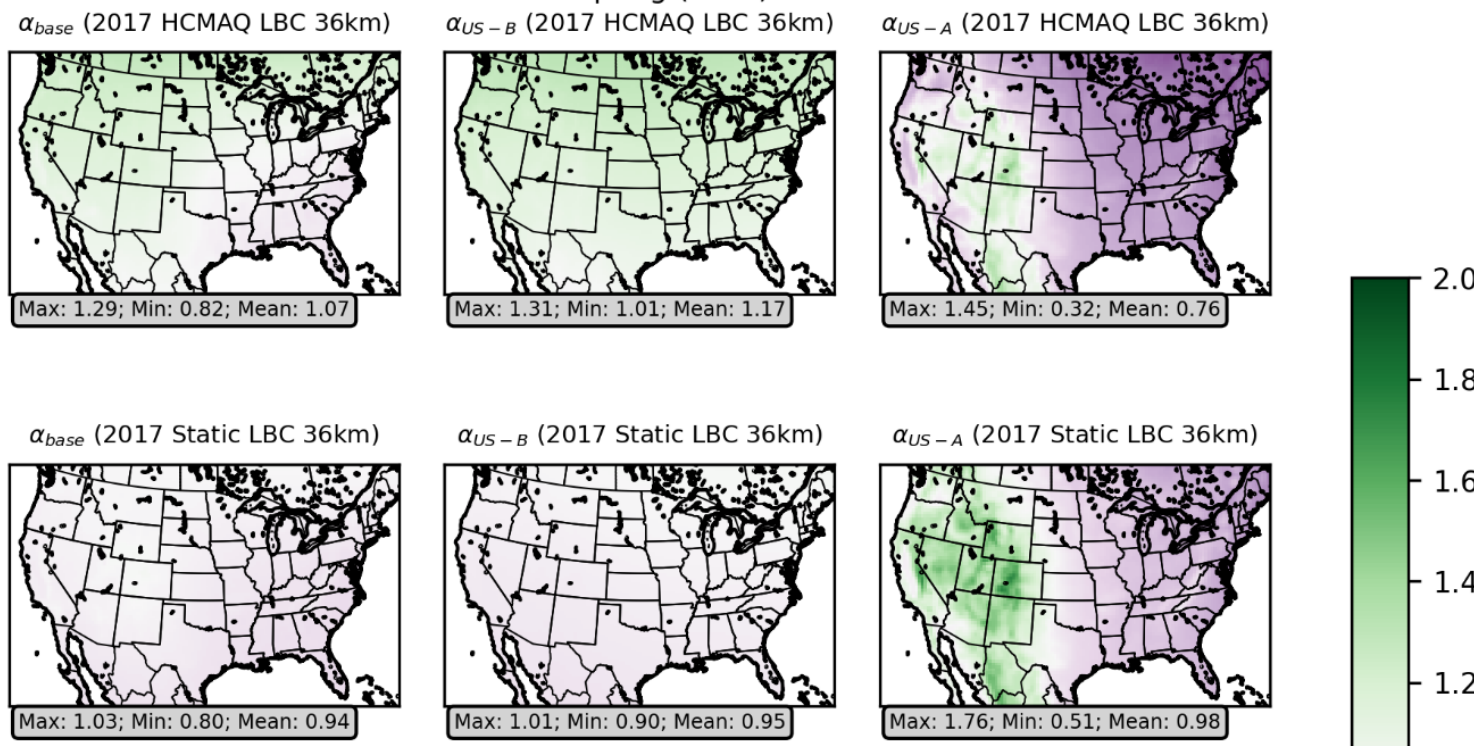

1.8

$-1.6$

1.4

1.2

1.0

$\alpha_{\text {base }}$ (2016 CMAQ 12km)
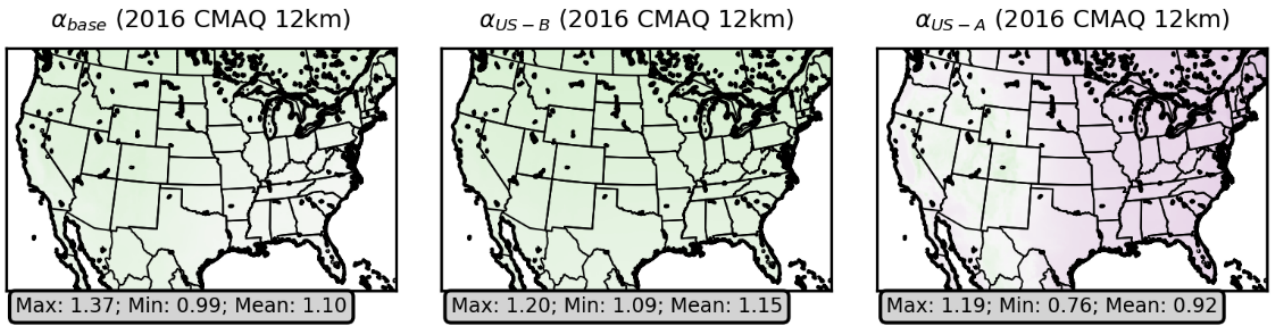

$-0.8$

0.8

0.6

$-0.4$

$-0.2$
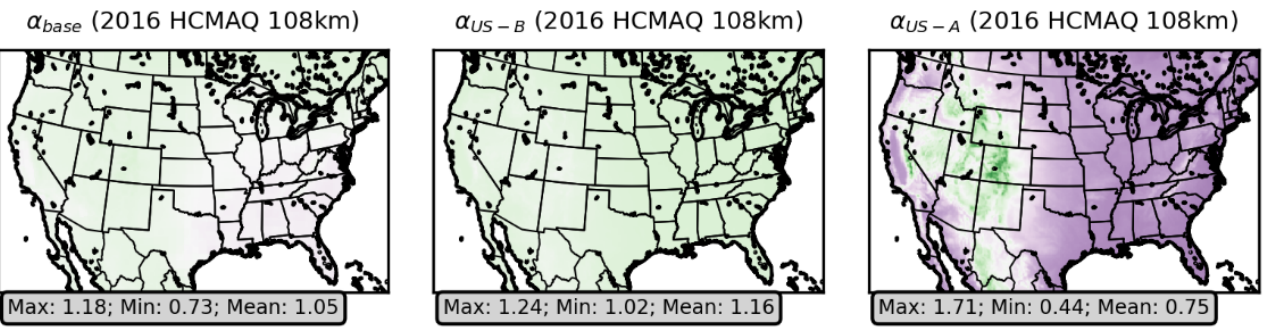

Figure S13. Spring (March, April, May) average of $\mathrm{O}_{3}$ adjustment ratios for all cases. Max, min, and mean refer to the maximum, minimum, and mean values over the contiguous US. $\alpha=$ $\left[\mathrm{O}_{3}\right]^{\text {simulated }} /\left[\mathrm{O}_{3}\right]^{\text {adjusted }}$. 
Summer (JJA) Mean $\alpha$ Values
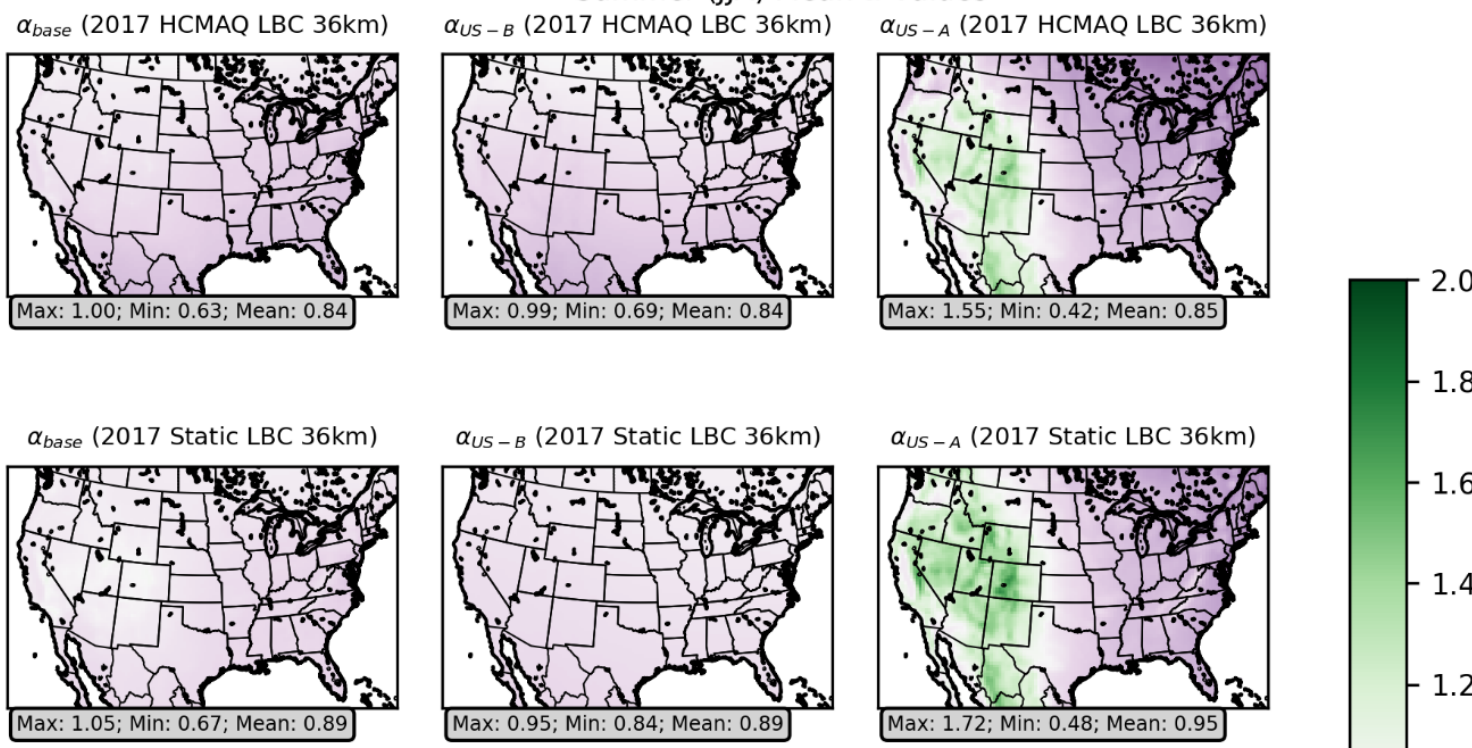

1.8

$-1.6$

1.4

1.2

Max: 1.72; Min: 0.48; Mean: 0.95

$-1.0$

$\alpha_{\text {base }}(2016$ CMAQ 12km)
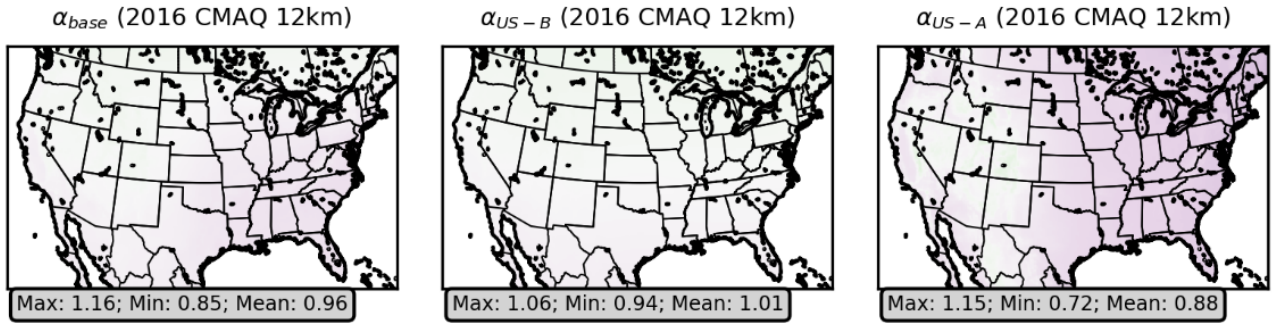

0.8

0.6

0.4

0.2
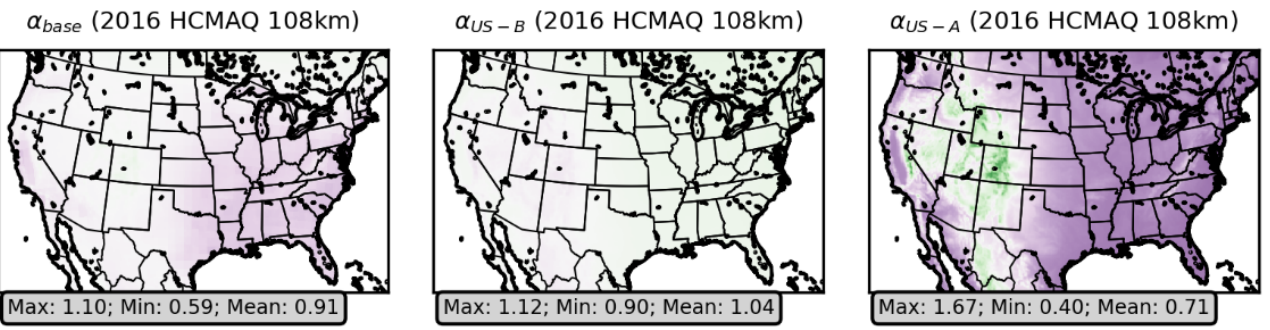

Figure S14. Summer (June, July, August) average of $\mathrm{O}_{3}$ adjustment ratios for all cases. Max, min, and mean refer to the maximum, minimum, and mean values over the contiguous US. $\alpha=$ $\left[\mathrm{O}_{3}\right]^{\text {simulated }} /\left[\mathrm{O}_{3}\right]^{\text {adjusted }}$. 
Autumn (SON) Mean $\alpha$ Values
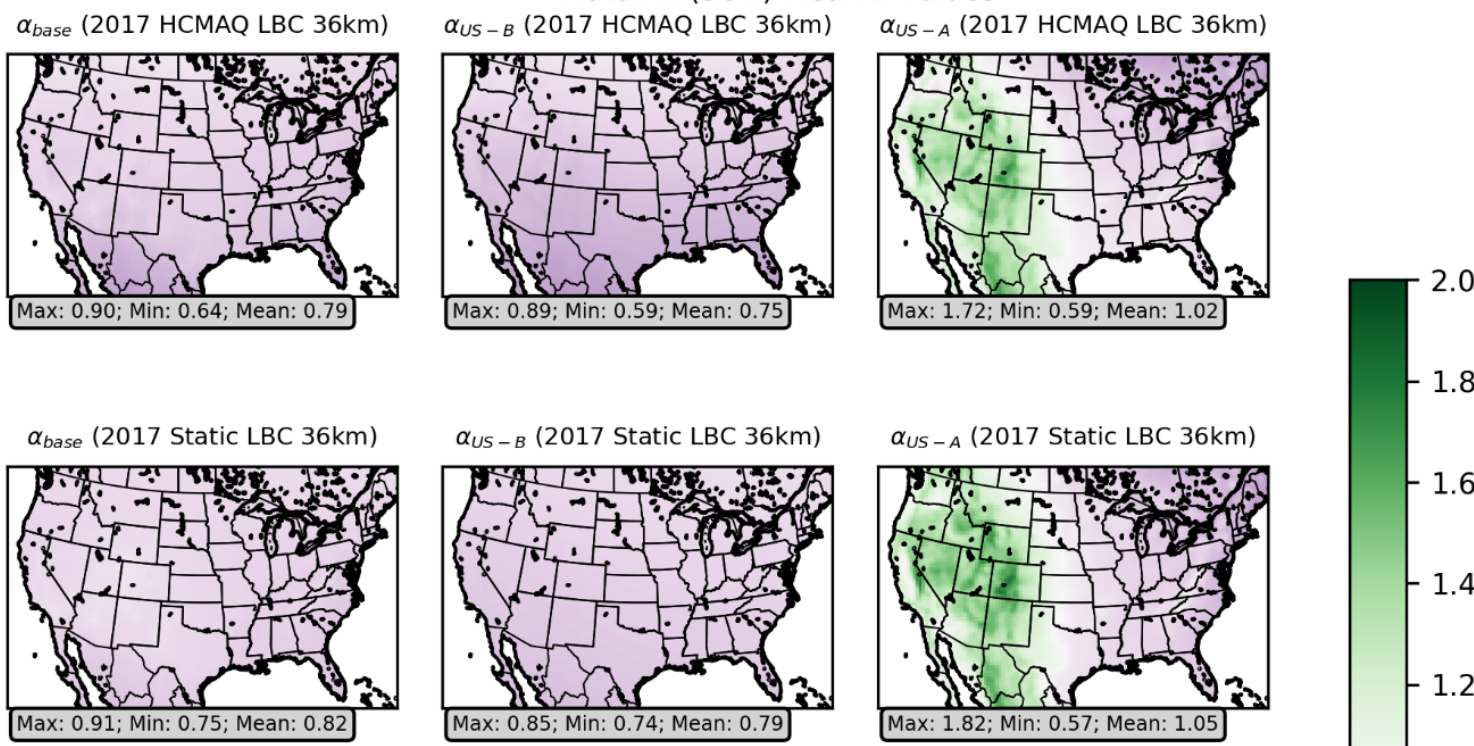

1.8

$-1.6$

1.4

1.2

1.0

$\alpha_{\text {base }}(2016$ CMAQ $12 \mathrm{~km}$ )
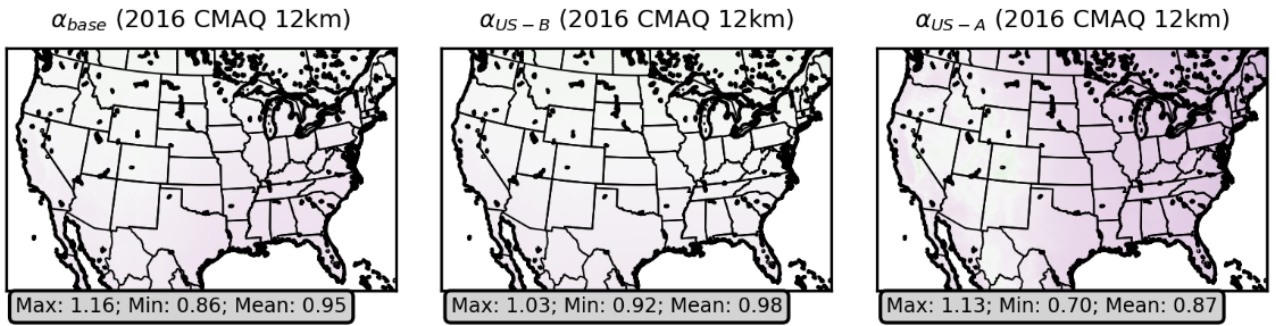

$-0.8$

0.8

0.6

0.4

$-0.2$
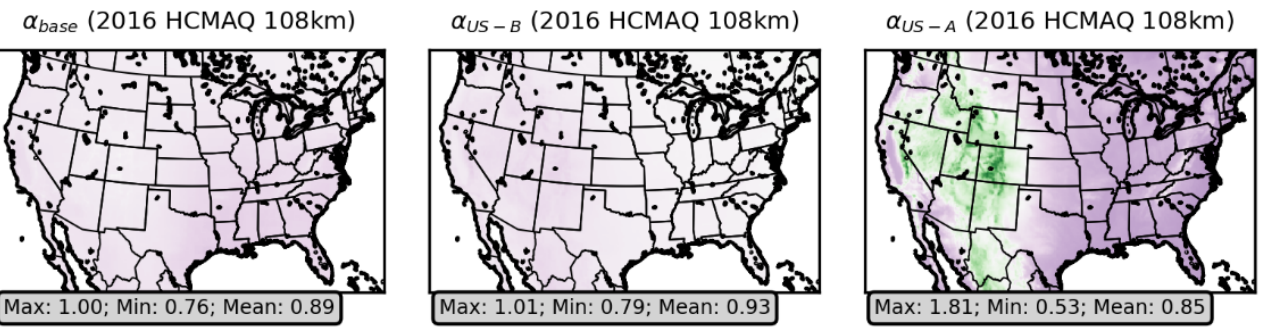

Figure S15. Autumn (September, October, November) average of $\mathrm{O}_{3}$ adjustment ratios for all cases. Max, min, and mean refer to the maximum, minimum, and mean values over the contiguous US. $\alpha=\left[\mathrm{O}_{3}\right]^{\text {simulated }} /\left[\mathrm{O}_{3}\right]^{\text {adjusted }}$. 


\section{Seasonal Average Ozone Adjustments $(\Delta)$}

Annual Mean $\Delta \mathrm{O}_{3}$ Values
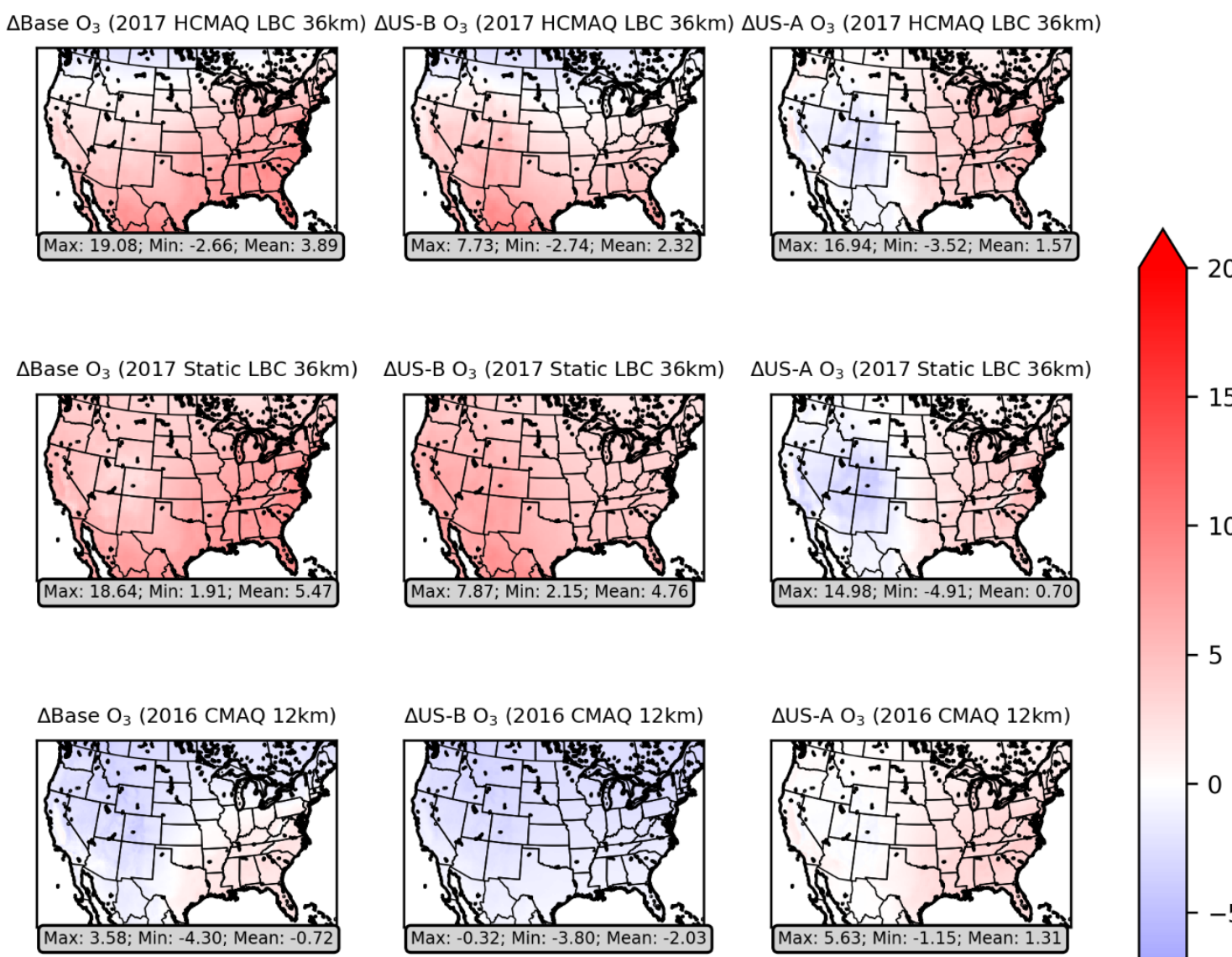

$\triangle$ Base $\mathrm{O}_{3}(2016$ HCMAQ 108km)
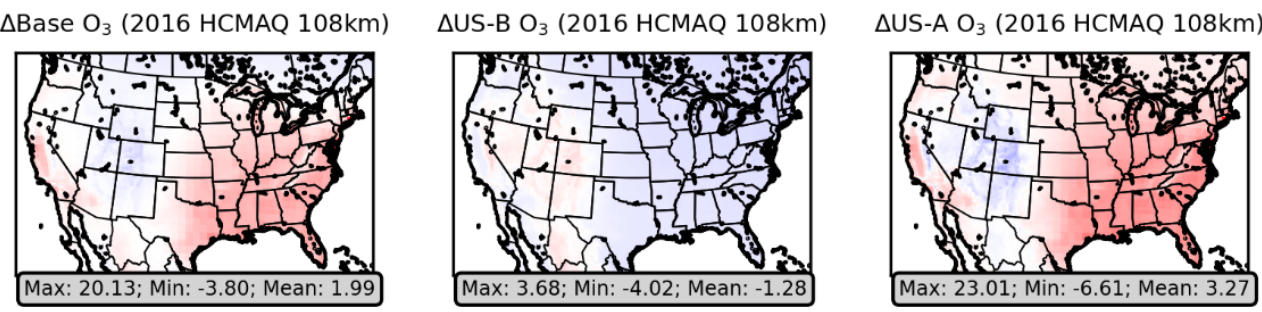

Figure S16. Annual average of $\mathrm{O}_{3}$ adjustments for all cases. Max, min, and mean refer to the maximum, minimum, and mean values over the contiguous US. $\Delta=\left[\mathrm{O}_{3}\right]_{\text {simulated }}-\left[\mathrm{O}_{3}\right]_{\text {adjusted }}=(1$ $-\alpha)^{*}\left[\mathrm{O}_{3}\right]_{\text {simulated }}$ 
Winter (DJF) Mean $\Delta \mathrm{O}_{3}$ Values

$\triangle$ Base $\mathrm{O}_{3}(2017$ HCMAQ LBC $36 \mathrm{~km}) \triangle$ US-B O 3 (2017 HCMAQ LBC 36km) $\triangle$ US-A O O $_{3}(2017$ HCMAQ LBC 36km)
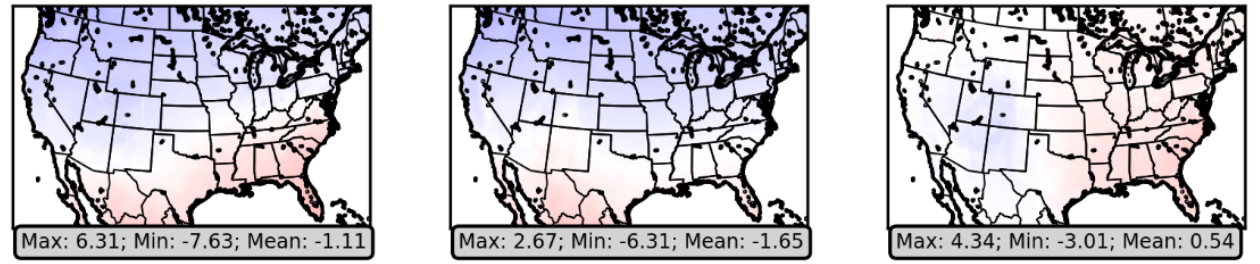

$\triangle$ Base $\mathrm{O}_{3}$ (2017 Static LBC $36 \mathrm{~km}$ )
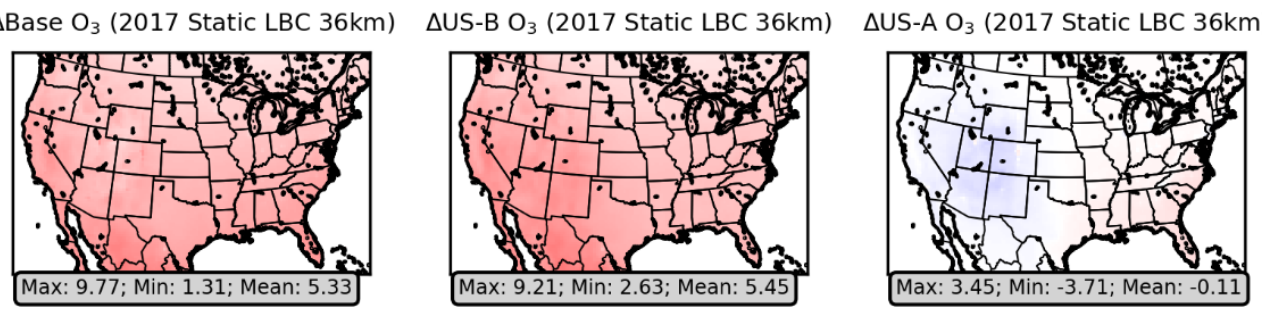

$-15$
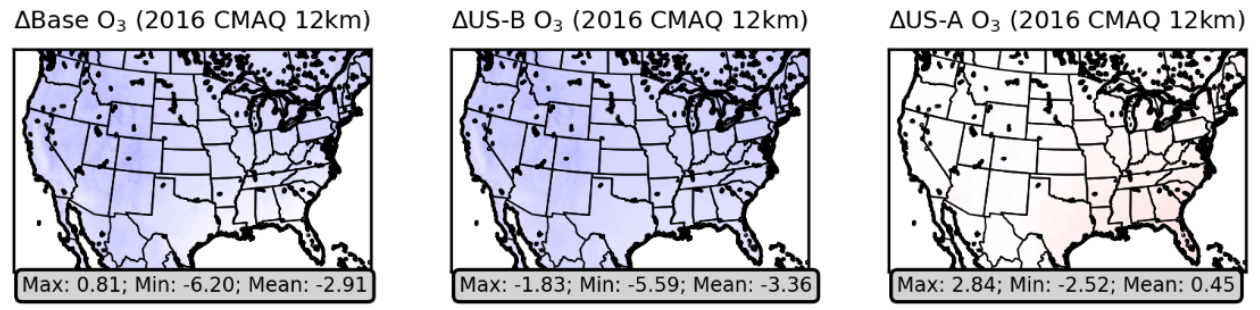

$\triangle$ Base $\mathrm{O}_{3}$ (2016 HCMAQ 108km)

$\triangle$ US-B O ( $_{3}(2016$ HCMAQ 108km)

$\triangle$ US-A O ${ }_{3}$ (2016 HCMAQ 108km)
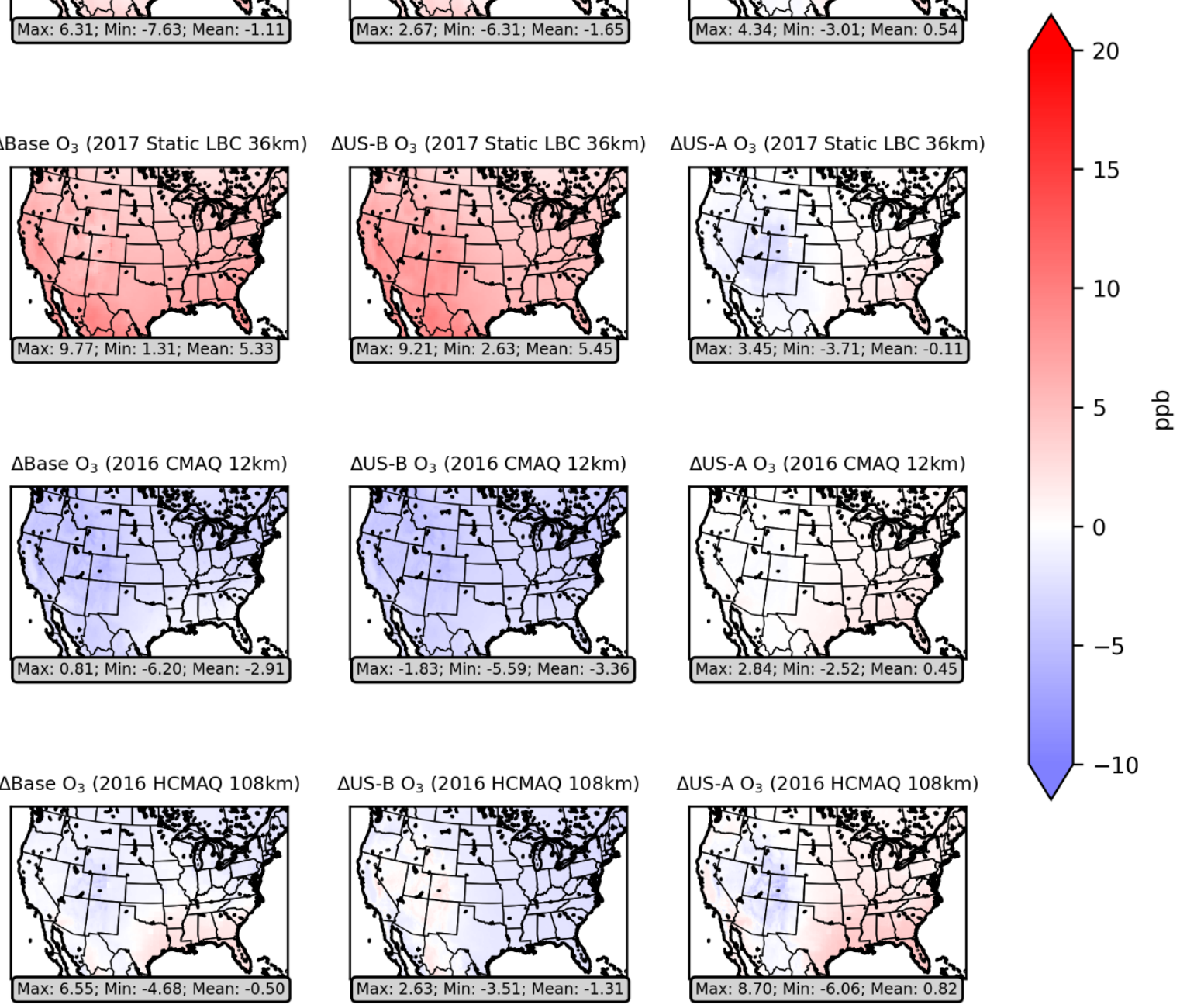

Figure S17. Winter (DJF) average of $\mathrm{O}_{3}$ adjustments for all cases. Max, min, and mean refer to the maximum, minimum, and mean values over the contiguous US. $\Delta=\left[\mathrm{O}_{3}\right]_{\text {simulated }}-\left[\mathrm{O}_{3}\right]_{\text {adjusted }}=$ $(1-\alpha) *\left[\mathrm{O}_{3}\right]_{\text {simulated }}$ 
Spring (MAM) Mean $\triangle \mathrm{O}_{3}$ Values

$\triangle$ Base $\mathrm{O}_{3}\left(2017\right.$ HCMAQ LBC 36km) $\triangle$ US-B O ( $_{3}(2017$ HCMAQ LBC 36km) $\triangle$ US-A O 3 (2017 HCMAQ LBC 36km)
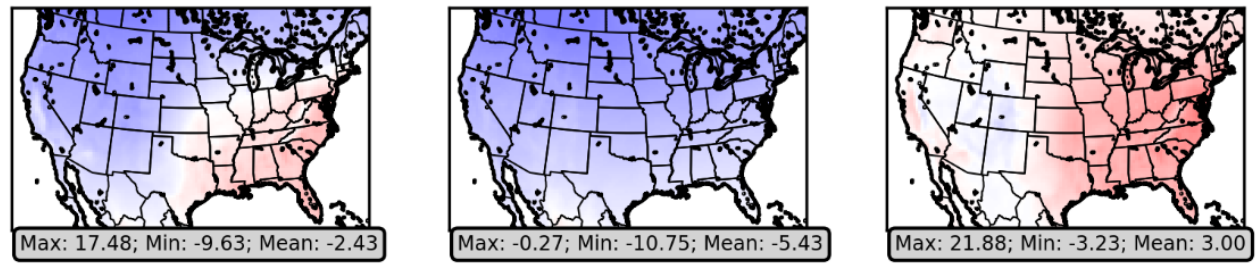

$\triangle$ Base $\mathrm{O}_{3}$ (2017 Static LBC 36km)

$\triangle \mathrm{US}-\mathrm{B} \mathrm{O}_{3}(2017$ Static LBC $36 \mathrm{~km})$
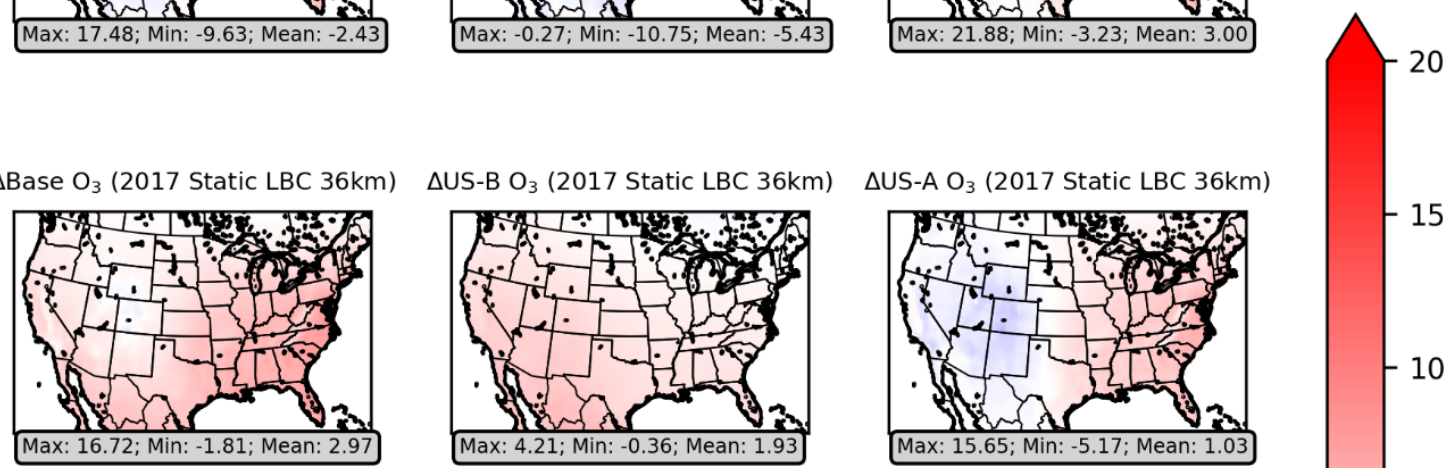

$-15$
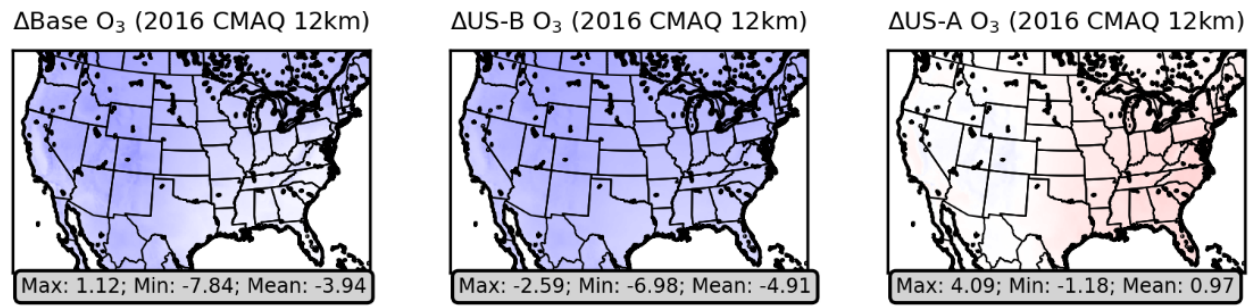

$\triangle$ Base $\mathrm{O}_{3}(2016 \mathrm{HCMAQ} 108 \mathrm{~km})$

$\triangle \mathrm{US}-\mathrm{B} \mathrm{O}_{3}(2016 \mathrm{HCMAQ} 108 \mathrm{~km})$

$\triangle$ US-A O $\mathrm{O}_{3}(2016$ HCMAQ $108 \mathrm{~km})$
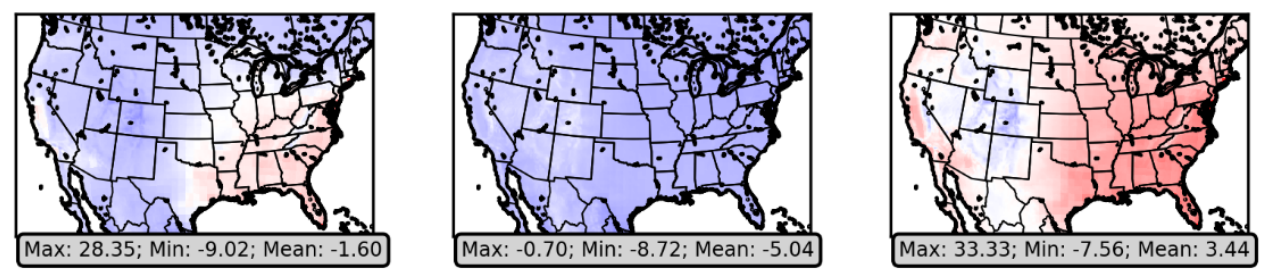

Figure S18. Spring (MAM) average of $\mathrm{O}_{3}$ adjustments for all cases. Max, min, and mean refer to the maximum, minimum, and mean values over the contiguous US. $\Delta=\left[\mathrm{O}_{3}\right]_{\text {simulated }}-\left[\mathrm{O}_{3}\right]_{\mathrm{adjusted}}=$ $(1-\alpha) *\left[\mathrm{O}_{3}\right]_{\text {simulated }}$ 
Summer (JJA) Mean $\Delta \mathrm{O}_{3}$ Values

$\triangle$ Base $\mathrm{O}_{3}\left(2017\right.$ HCMAQ LBC 36km) $\triangle$ US-B O O $_{3}(2017$ HCMAQ LBC 36km) $\triangle$ US-A O 3 (2017 HCMAQ LBC 36km)
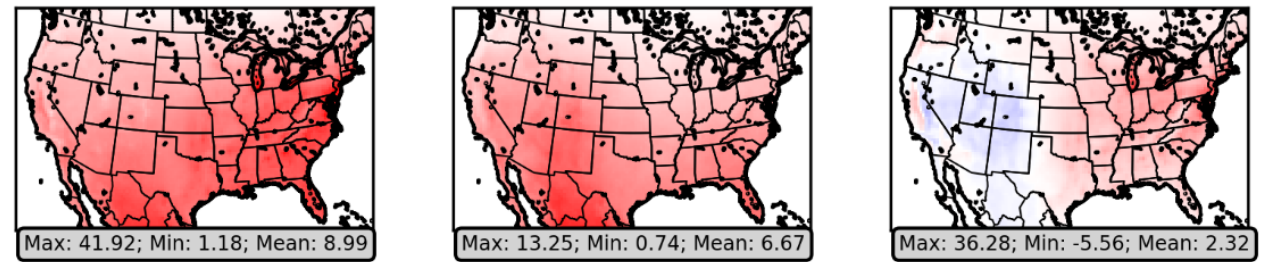

$\triangle$ Base $\mathrm{O}_{3}$ (2017 Static LBC 36km)
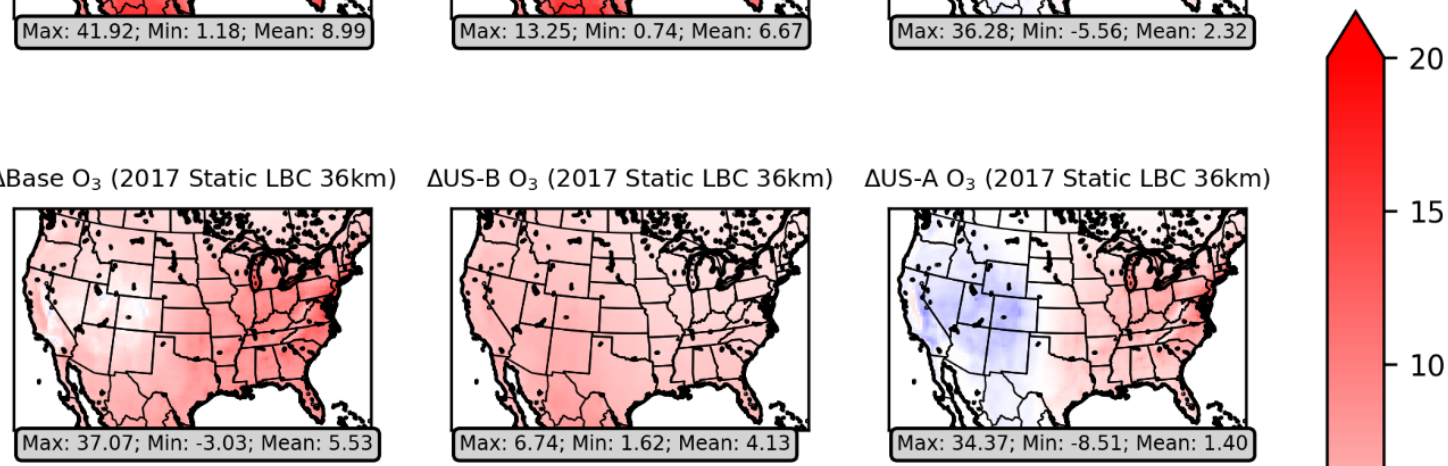

$\triangle U S-B O_{3}(2016$ CMAQ 12km)

$\triangle$ Base $\mathrm{O}_{3}(2016 \mathrm{CMAQ} 12 \mathrm{~km})$
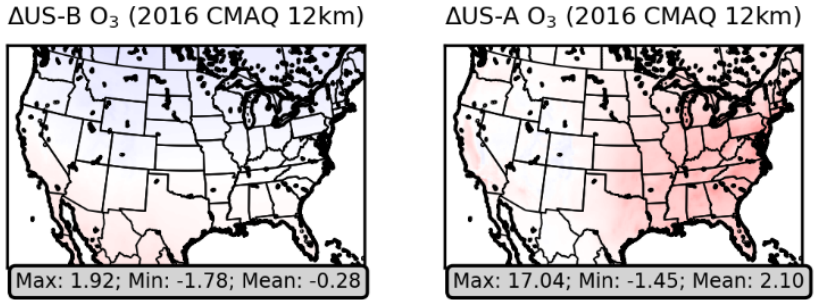

$\triangle$ Base $\mathrm{O}_{3}(2016 \mathrm{HCMAQ} 108 \mathrm{~km})$

$\triangle \mathrm{US}-\mathrm{B} \mathrm{O}_{3}(2016 \mathrm{HCMAQ} 108 \mathrm{~km})$

$\triangle$ US-A O $\mathrm{O}_{3}(2016$ HCMAQ $108 \mathrm{~km})$
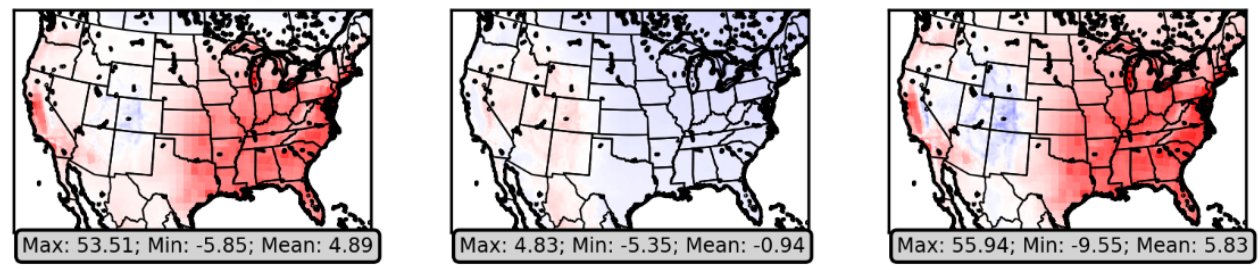

Figure S19. Summer (JJA) average of $\mathrm{O}_{3}$ adjustments for all cases. Max, min, and mean refer to the maximum, minimum, and mean values over the contiguous US. $\Delta=\left[\mathrm{O}_{3}\right]_{\text {simulated }}-\left[\mathrm{O}_{3}\right]_{\text {adjusted }}=$ $(1-\alpha) *\left[\mathrm{O}_{3}\right]_{\text {simulated. }}$ 
Autumn (SON) Mean $\Delta \mathrm{O}_{3}$ Values

$\triangle$ Base $\mathrm{O}_{3}\left(2017\right.$ HCMAQ LBC 36km) $\triangle$ US-B O ( $_{3}(2017$ HCMAQ LBC 36km) $\triangle$ US-A O 3 (2017 HCMAQ LBC 36km)
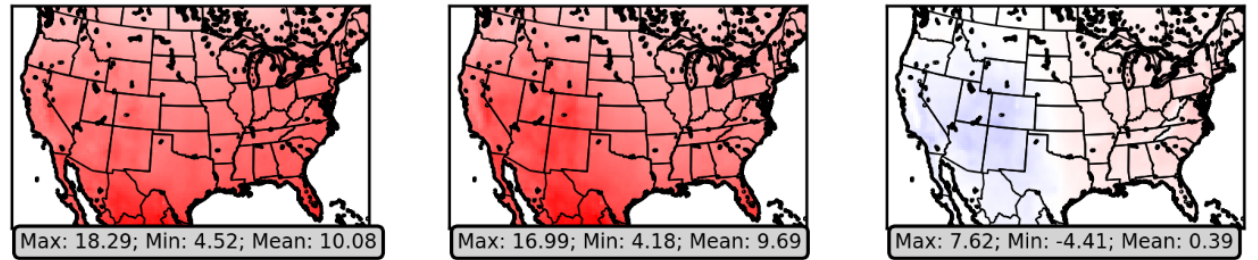

$\triangle$ Base $\mathrm{O}_{3}$ (2017 Static LBC $36 \mathrm{~km}$ )

$\triangle \mathrm{US}-\mathrm{B} \mathrm{O}_{3}(2017$ Static LBC $36 \mathrm{~km})$
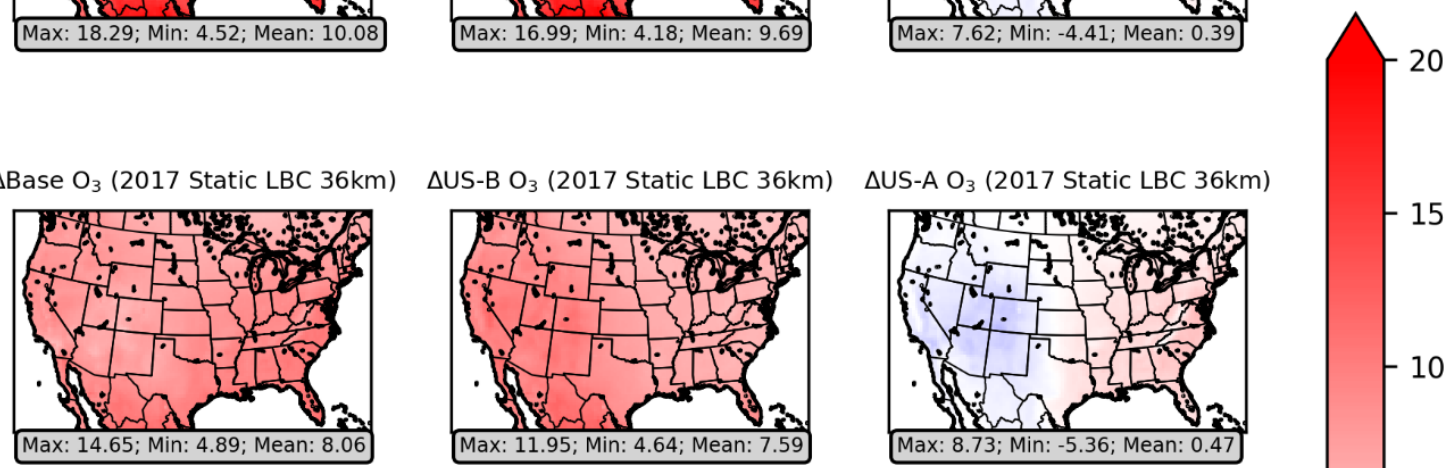

$\triangle$ Base $\mathrm{O}_{3}(2016 \mathrm{CMAQ} 12 \mathrm{~km})$

$\triangle$ US-B O 3 (2016 CMAQ $12 \mathrm{~km})$
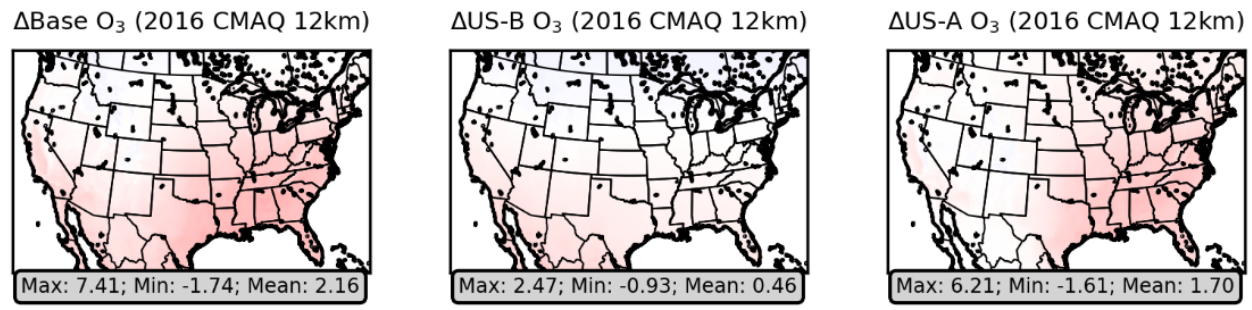

$\triangle$ Base $\mathrm{O}_{3}(2016 \mathrm{HCMAQ} 108 \mathrm{~km})$

$\triangle$ US-B O ( $_{3}(2016$ HCMAQ 108km)

$\triangle$ US-A O ${ }_{3}$ (2016 HCMAQ 108km)
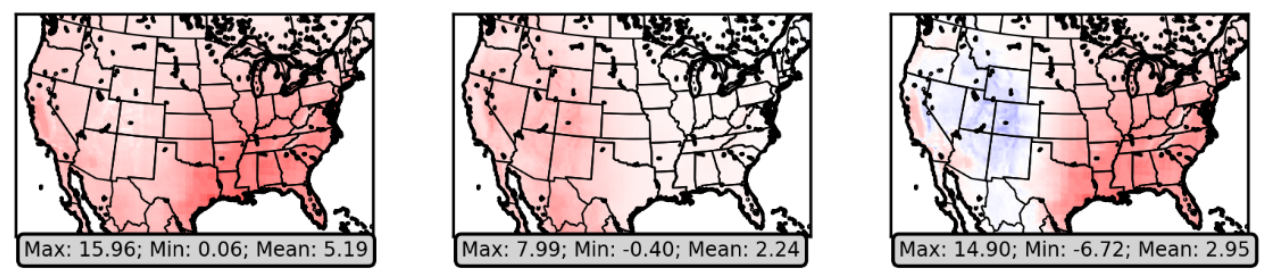

Figure S20. Autumn (SON) average of $\mathrm{O}_{3}$ adjustments for all cases. Max, min, and mean refer to the maximum, minimum, and mean values over the contiguous US. $\Delta=\left[\mathrm{O}_{3}\right]_{\text {simulated }}-\left[\mathrm{O}_{3}\right]_{\text {adjusted }}=$ $(1-\alpha) *\left[\mathrm{O}_{3}\right]_{\text {simulated }}$ 


\section{Background Ozone Metrics}

Table S16. Summary of annual and seasonal mean US-B $\mathrm{O}_{3}$ concentrations averaged across the US. Means values labeled with "all US grid cells" are averaged across the entire year for each model grid cell within the US border. Mean values labeled with "at monitoring sites" are averaged for grid cells that contain monitoring sites for days with valid observations. Also included are the mean US-B O 3 on the day of the fourth highest observed and modeled $\mathrm{O}_{3}$ and the average of the days of the top ten highest observed and modeled $\mathrm{O}_{3}$. The model resolution for each case is shown in parentheses. Adjusted values are using the regression model formulation without meteorological variables included.

\begin{tabular}{|c|c|c|c|c|c|c|c|c|}
\hline & $\begin{array}{c}2017 \\
\text { HCMAQ } \\
\text { BC (36km) } \\
\text { Simulated }\end{array}$ & $\begin{array}{c}2017 \\
\text { HCMAQ } \\
\text { BC (36km) } \\
\text { Adjusted }\end{array}$ & $\begin{array}{c}\text { 2017 Static } \\
\text { BC (36km) } \\
\text { Simulated }\end{array}$ & $\begin{array}{c}2017 \text { Static } \\
\text { BC (36km) } \\
\text { Adjusted }\end{array}$ & $\begin{array}{c}2016 \\
\text { CMAQ } \\
(12 \mathrm{~km}) \\
\text { Simulated }\end{array}$ & $\begin{array}{c}2016 \\
\text { CMAQ } \\
(12 \mathrm{~km}) \\
\text { Adjusted }\end{array}$ & $\begin{array}{c}2016 \\
\text { HCMAQ } \\
(108 \mathrm{~km}) \\
\text { Simulated }\end{array}$ & $\begin{array}{c}2016 \\
\text { HCMAQ } \\
(108 \mathrm{~km}) \\
\text { Adjusted }\end{array}$ \\
\hline $\begin{array}{c}\text { Annual } \\
\text { mean (at } \\
\text { monitoring } \\
\text { sites) }\end{array}$ & 32.21 & 35.84 & 31.41 & 28.66 & 30.24 & 30.34 & 32.11 \\
\hline $\begin{array}{c}\text { Annual } \\
\text { mean (all } \\
\text { US grid } \\
\text { cells) }\end{array}$ & 33.43 & 37.25 & 32.49 & 29.66 & 31.69 & 30.77 & 32.05 \\
\hline $\begin{array}{c}\text { DJF } \\
\text { seasonal } \\
\text { mean (at }\end{array}$ & 31.53 & 37.51 & 31.75 & 26.87 & 30.03 & 27.24 & 33.43 \\
\hline
\end{tabular}




\begin{tabular}{|c|c|c|c|c|c|c|c|c|}
\hline $\begin{array}{c}\text { monitoring } \\
\text { sites) }\end{array}$ & & & & & & & & \\
\hline $\begin{array}{c}\text { DJF } \\
\text { seasonal } \\
\text { mean (all } \\
\text { US grid } \\
\text { cells) }\end{array}$ & 31.25 & 36.75 & 31.31 & 26.23 & 29.61 & 25.97 & 27.31 & 31.25 \\
\hline $\begin{array}{c}\text { MAM } \\
\text { seasonal } \\
\text { mean (at } \\
\text { monitoring } \\
\text { sites) }\end{array}$ & 36.98 & 37.36 & 35.52 & 30.94 & 35.32 & 31.98 & 37.42 & 36.98 \\
\hline $\begin{array}{c}\text { MAM } \\
\text { seasonal } \\
\text { mean (all } \\
\text { US grid } \\
\text { cells) }\end{array}$ & 38.76 & 39.31 & 37.37 & 32.41 & 37.32 & 32.87 & 37.90 & 38.76 \\
\hline $\begin{array}{c}\text { JJA } \\
\text { seasonal } \\
\text { mean (at } \\
\text { monitoring } \\
\text { sites) }\end{array}$ & 32.30 & 34.64 & 30.79 & 28.13 & 28.23 & 31.20 & 32.70 & 32.30 \\
\hline $\begin{array}{c}\text { JJA } \\
\text { seasonal } \\
\text { mean (all } \\
\text { US grid } \\
\text { cells) }\end{array}$ & 34.94 & 36.96 & 32.83 & 30.73 & 31.01 & 33.75 & 34.69 & 34.94 \\
\hline $\begin{array}{c}\text { SON } \\
\text { seasonal }\end{array}$ & 26.77 & 34.22 & 26.92 & 28.10 & 27.28 & 29.71 & 27.93 & 26.77 \\
\hline
\end{tabular}




\begin{tabular}{|c|c|c|c|c|c|c|c|}
\hline $\begin{array}{c}\text { mean (at } \\
\text { monitoring } \\
\text { sites) }\end{array}$ & 28.68 & 35.96 & 28.37 & 29.21 & 28.75 & 30.40 & 28.16 \\
\hline $\begin{array}{c}\text { SON } \\
\text { seasonal } \\
\text { mean (all } \\
\text { US grid } \\
\text { cells) }\end{array}$ & 36.13 & 35.24 & 32.10 & 31.80 & 33.54 & 34.78 & 38.01 \\
\hline $\begin{array}{c}\text { Fourth } \\
\text { observed }\end{array}$ & 35.98 & 37.24 & 32.89 & 32.28 & 32.55 & 35.95 & 37.56 \\
\hline $\begin{array}{c}\text { Fourth } \\
\text { modeled }\end{array}$ & 35.92 & 35.25 & 32.09 & 32.23 & 34.04 & 34.78 & 38.13 \\
\hline $\begin{array}{c}\text { Top ten } \\
\text { observed }\end{array}$ & 35.81 & 37.17 & 32.78 & 32.43 & 32.77 & 35.24 & 36.75 \\
\hline $\begin{array}{c}\text { Top ten } \\
\text { modeled }\end{array}$ & & & & & & 35 \\
\hline
\end{tabular}



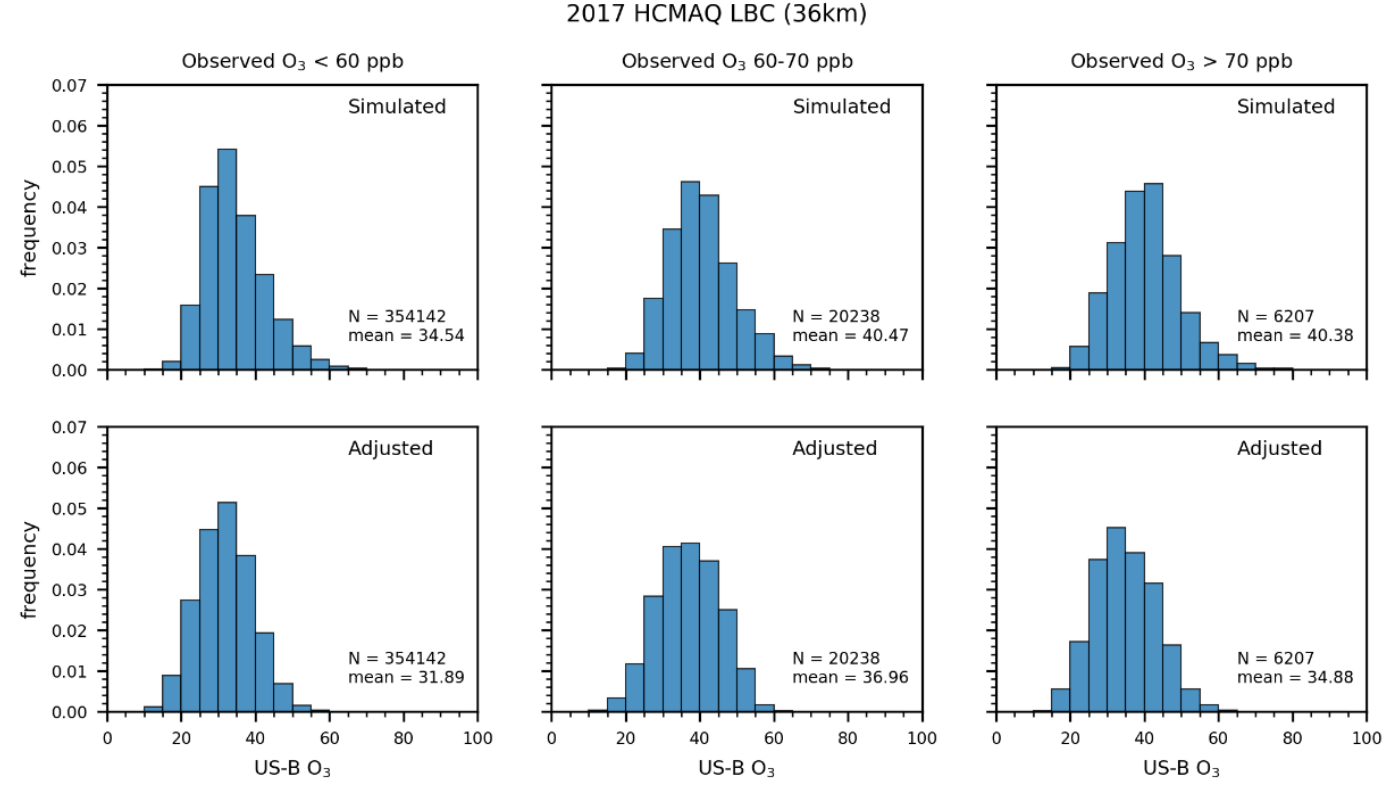

Figure S21. Histograms of US-B $\mathrm{O}_{3}$ for 2017 with HCMAQ boundary conditions at monitoring site locations for observed $\mathrm{O}_{3}$ less than $60 \mathrm{ppb}$, between 60 and $70 \mathrm{ppb}$, and greater than $70 \mathrm{ppb}$. The model resolution is provided in parentheses.

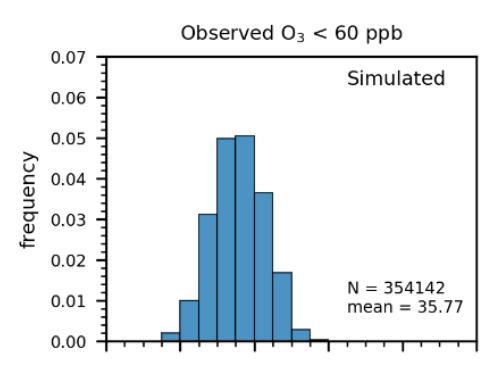

2017 Static LBC (36km)
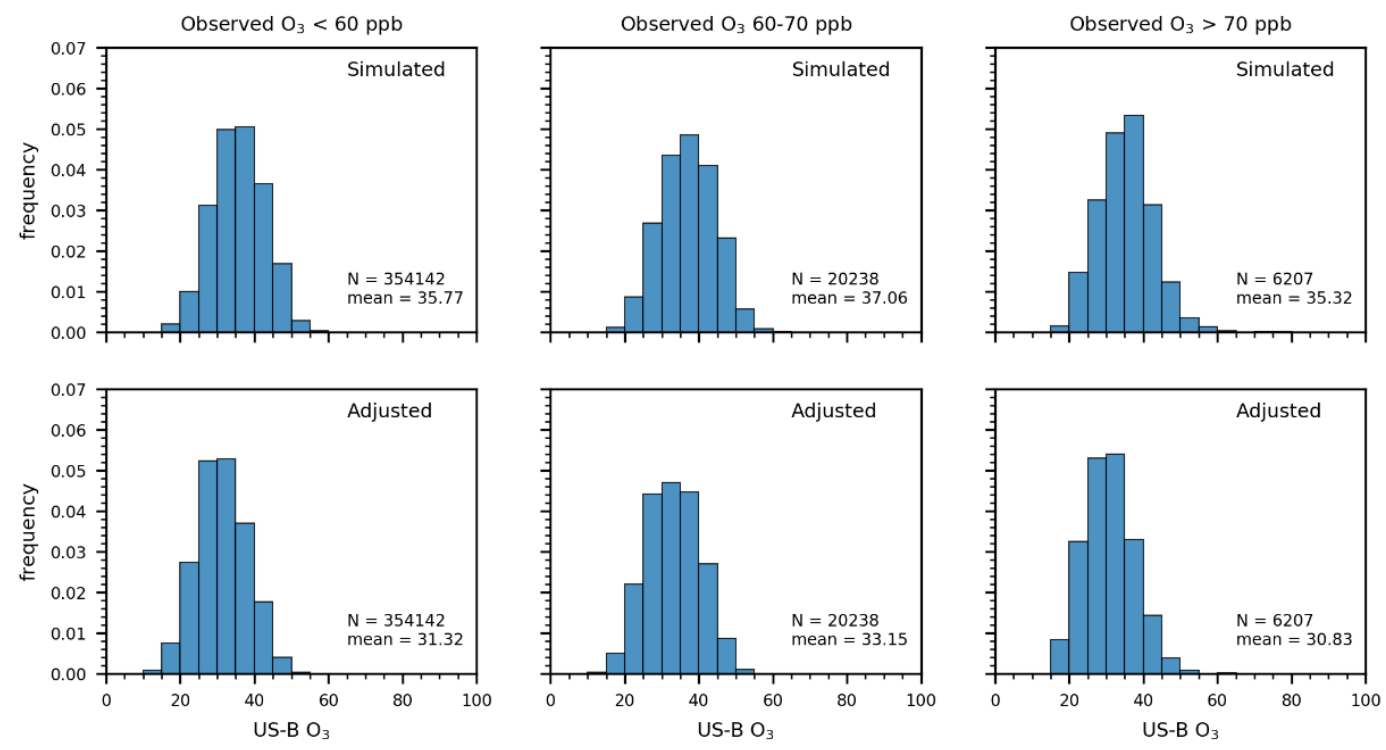
Figure S22. Histograms of US-B $\mathrm{O}_{3}$ for 2017 with static boundary conditions at monitoring site locations for observed $\mathrm{O}_{3}$ less than $60 \mathrm{ppb}$, between 60 and $70 \mathrm{ppb}$, and greater than $70 \mathrm{ppb}$. The model resolution is provided in parentheses.
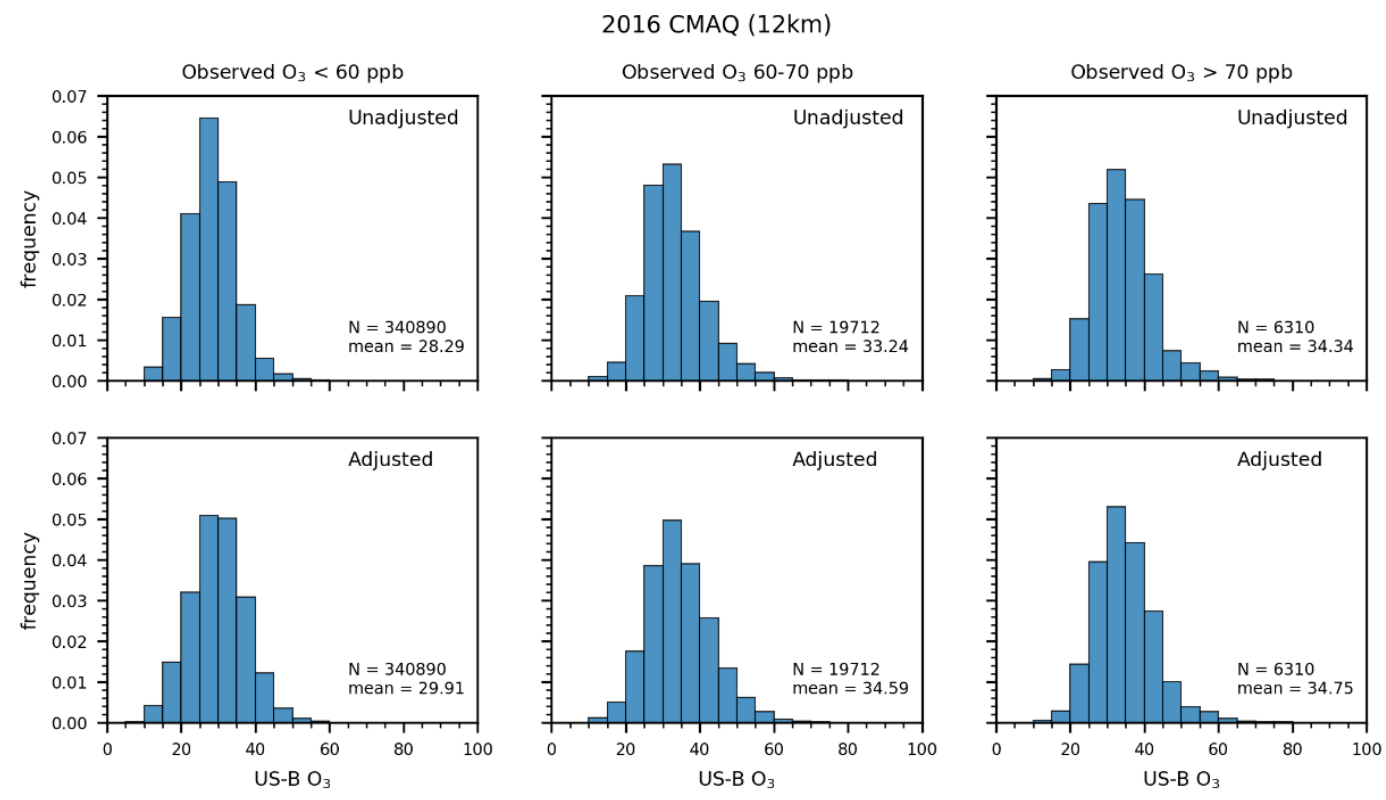

Figure S23. Histograms of US-B $\mathrm{O}_{3}$ for 2016 CMAQ at monitoring site locations for observed $\mathrm{O}_{3}$ less than $60 \mathrm{ppb}$, between 60 and $70 \mathrm{ppb}$, and greater than $70 \mathrm{ppb}$. The model resolution is provided in parentheses. 

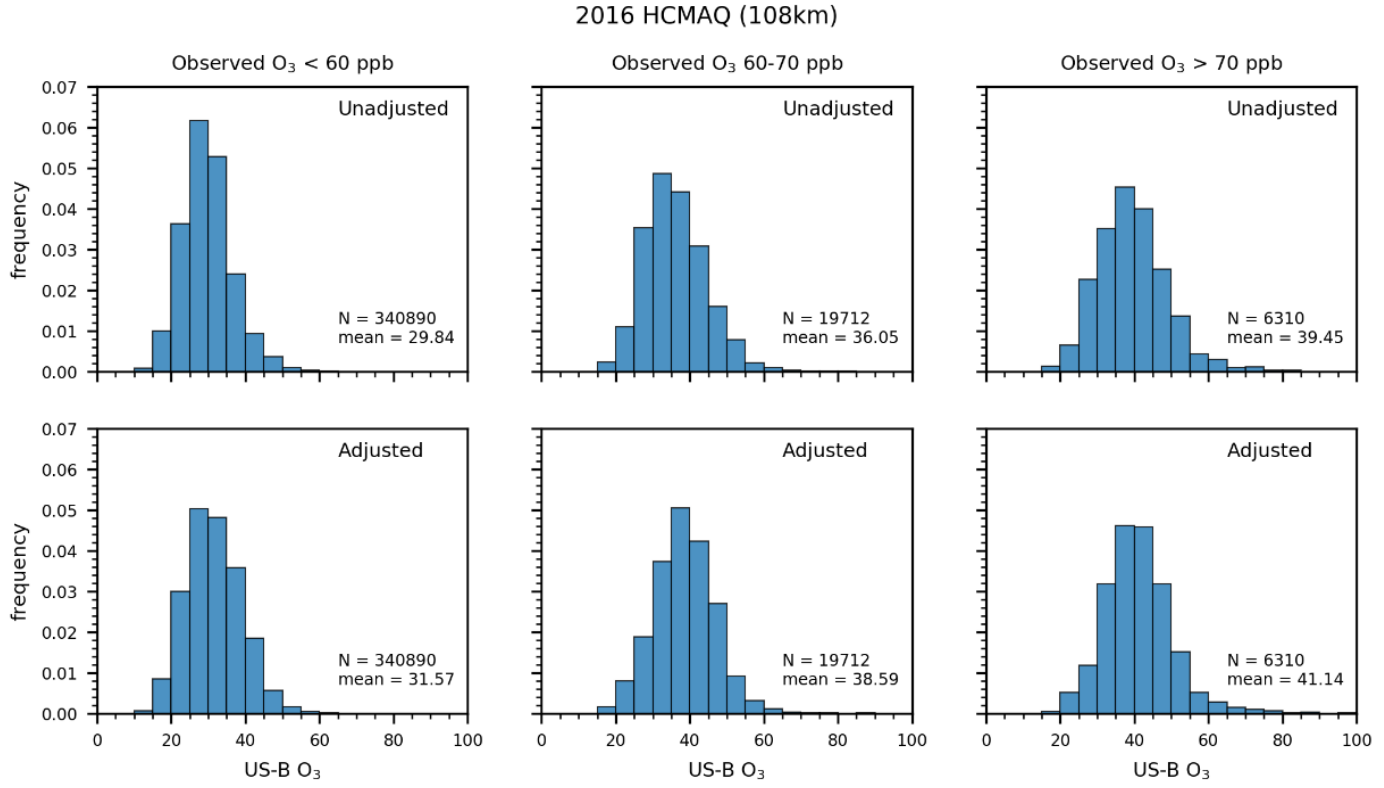

Figure S24. Histograms of US-B $\mathrm{O}_{3}$ for $2016 \mathrm{HCMAQ}$ at monitoring site locations for observed $\mathrm{O}_{3}$ less than $60 \mathrm{ppb}$, between 60 and $70 \mathrm{ppb}$, and greater than $70 \mathrm{ppb}$. The model resolution is provided in parentheses. 


\section{Annual and Seasonal Average Ozone Concentrations}

Annual Mean Simulated $\mathrm{O}_{3}$ Values

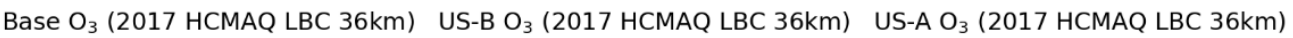

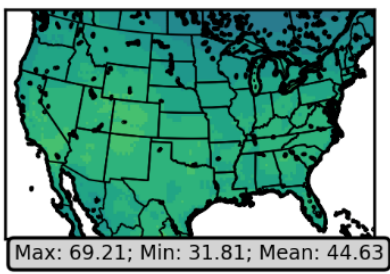

Base $\mathrm{O}_{3}$ (2017 Static LBC 36km)

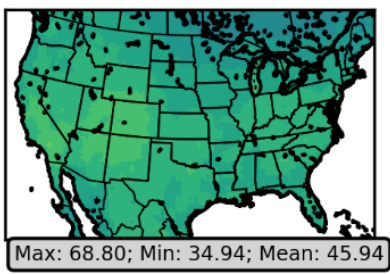

Base $\mathrm{O}_{3}(2016$ CMAQ $12 \mathrm{~km})$

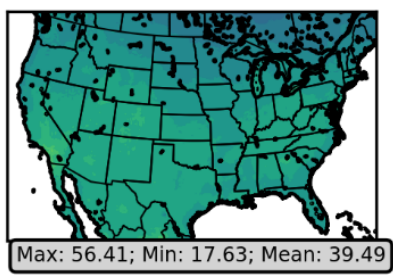

Max: 56.41; Min: 17.63; Mean: 39.49

Base $\mathrm{O}_{3}(2016 \mathrm{HCMAQ} 108 \mathrm{~km})$

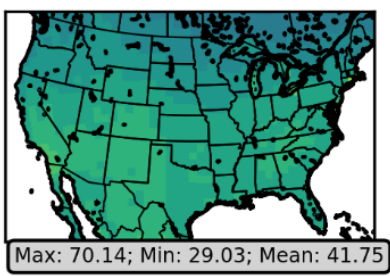

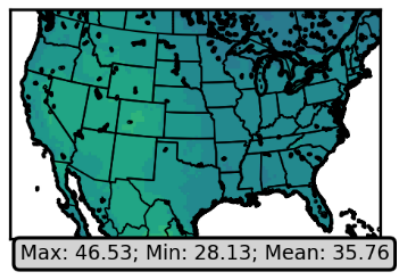

US-B O $\mathrm{O}_{3}$ (2017 Static LBC 36km)

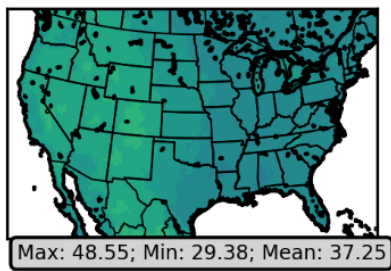

US-B $\mathrm{O}_{3}(2016$ CMAQ $12 \mathrm{~km})$

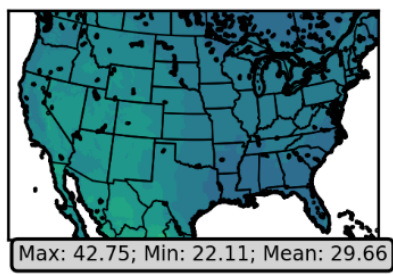

US-B O $\mathrm{O}_{3}(2016$ HCMAQ 108km)

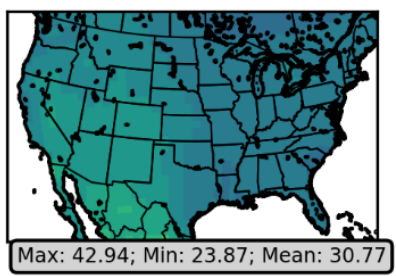

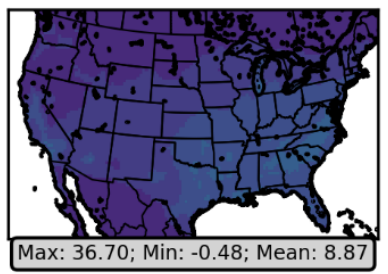

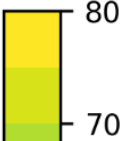

US-A $\mathrm{O}_{3}(2017$ Static LBC 36km)

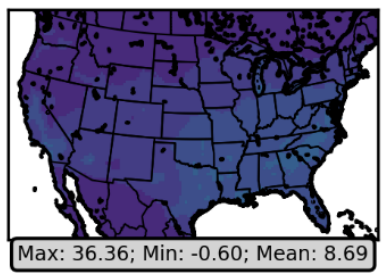

60

50

$-40$

응

US-A O $\mathrm{O}_{3}(2016$ CMAQ 12km)

$-30$

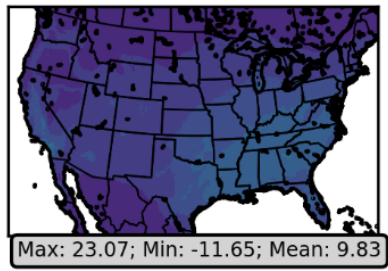

US-A $\mathrm{O}_{3}(2016$ HCMAQ 108km)

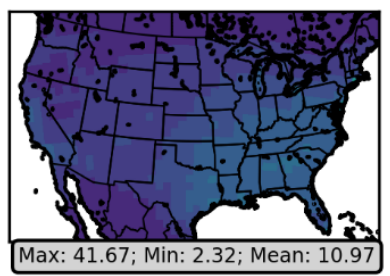

Figure S25. Annual average of CMAQ-simulated $\mathrm{O}_{3}$ concentration for all cases. Max, min, and mean refer to the maximum, minimum, and mean values over the contiguous US. 
Annual Mean Adjusted $\mathrm{O}_{3}$ Values

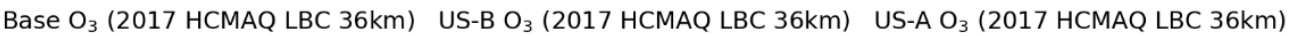
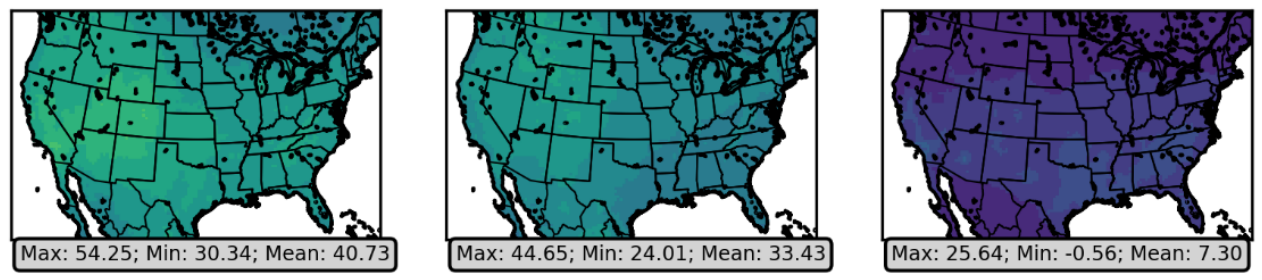

Base $\mathrm{O}_{3}$ (2017 Static LBC 36km)

US-B O $\mathrm{O}_{3}$ (2017 Static LBC 36km)
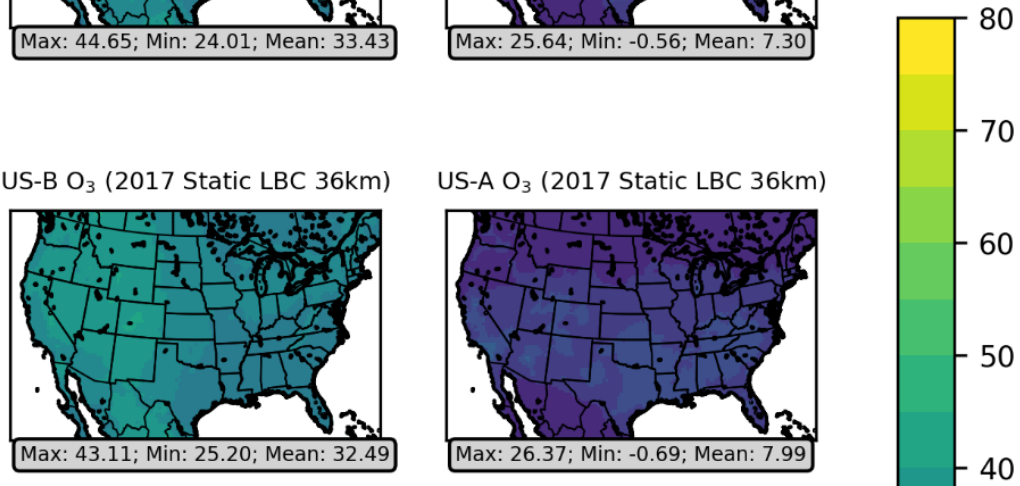

Base $\mathrm{O}_{3}(2016$ CMAQ $12 \mathrm{~km})$

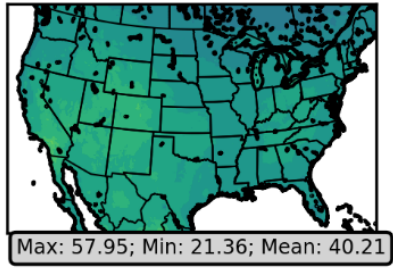

US-B $\mathrm{O}_{3}$ (2016 CMAQ 12km)
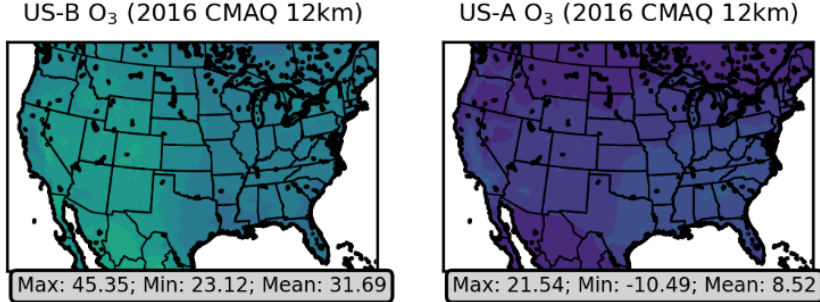

을

Base $\mathrm{O}_{3}(2016 \mathrm{HCMAQ} 108 \mathrm{~km})$
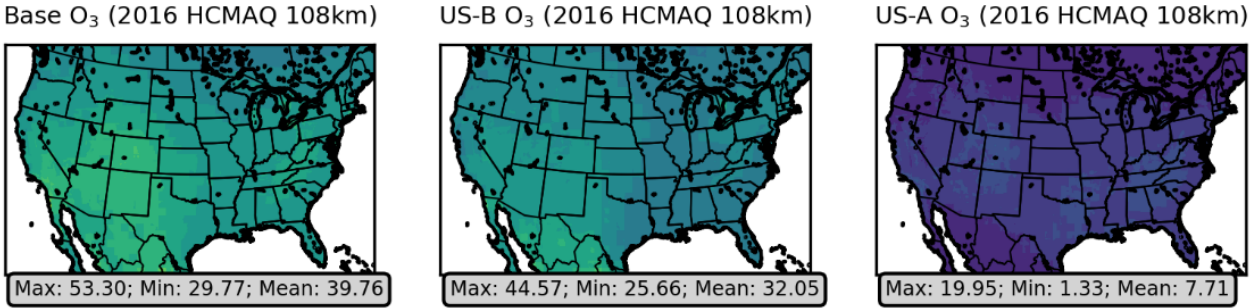

Figure S26. Annual average of adjusted $\mathrm{O}_{3}$ concentration for all cases. Max, min, and mean refer to the maximum, minimum, and mean values over the contiguous US. 
Winter (DJF) Mean Simulated $\mathrm{O}_{3}$ Values

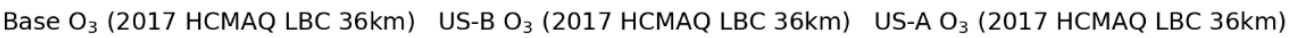
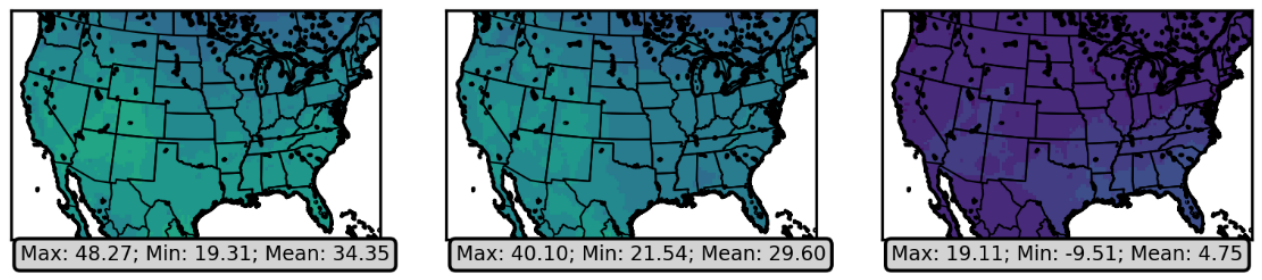

Base $\mathrm{O}_{3}$ (2017 Static LBC 36km)

US-B O $\mathrm{O}_{3}$ (2017 Static LBC 36km)
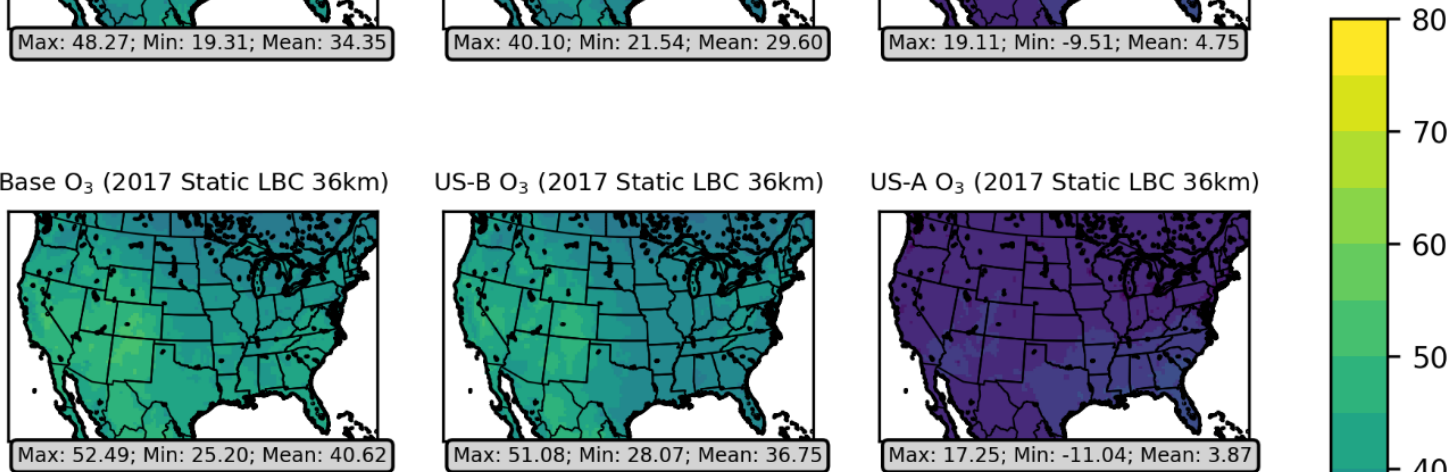

응

Base $\mathrm{O}_{3}(2016 \mathrm{CMAQ} 12 \mathrm{~km})$

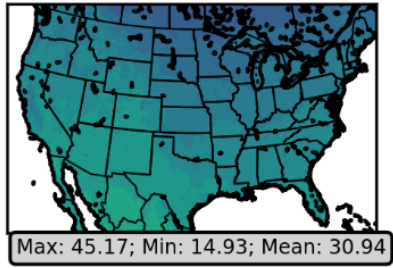

US-B $\mathrm{O}_{3}$ (2016 CMAQ 12km)
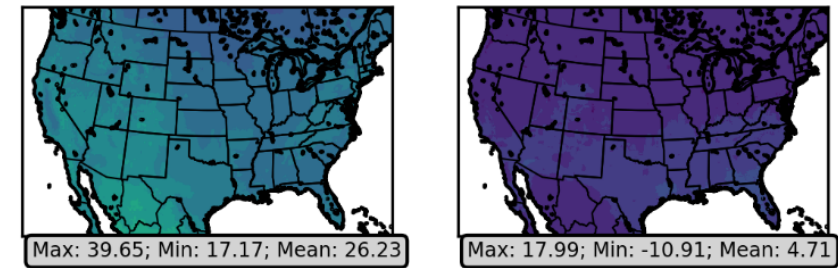

$-20$

$-10$

Base $\mathrm{O}_{3}(2016 \mathrm{HCMAQ} 108 \mathrm{~km})$
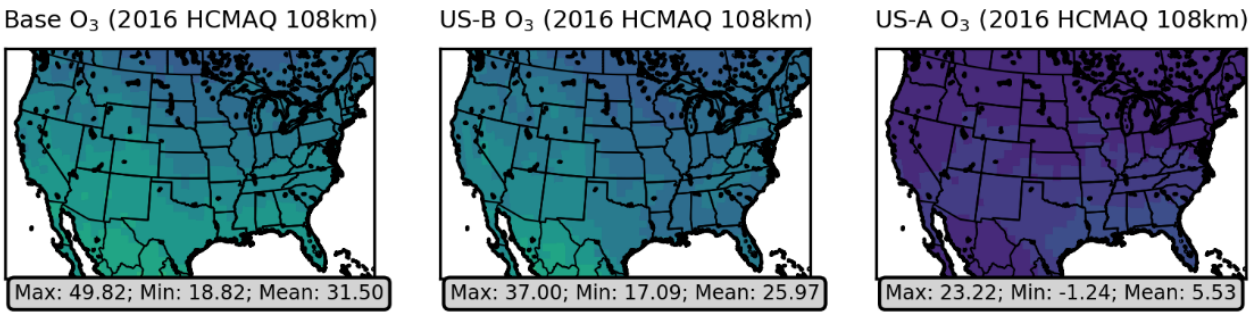

Figure S27. Winter (December, January, February) average of CMAQ-simulated $\mathrm{O}_{3}$ concentration for all cases. Max, min, and mean refer to the maximum, minimum, and mean values over the contiguous US. 
Winter (DJF) Mean Adjusted $\mathrm{O}_{3}$ Values

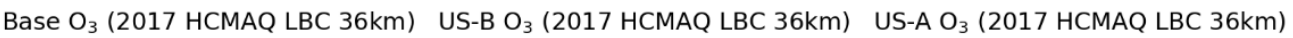
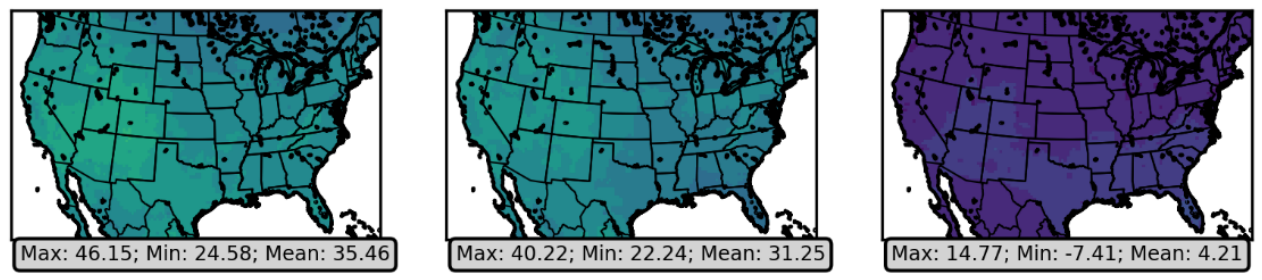

Base $\mathrm{O}_{3}$ (2017 Static LBC 36km)

US-B O $\mathrm{O}_{3}$ (2017 Static LBC 36km)
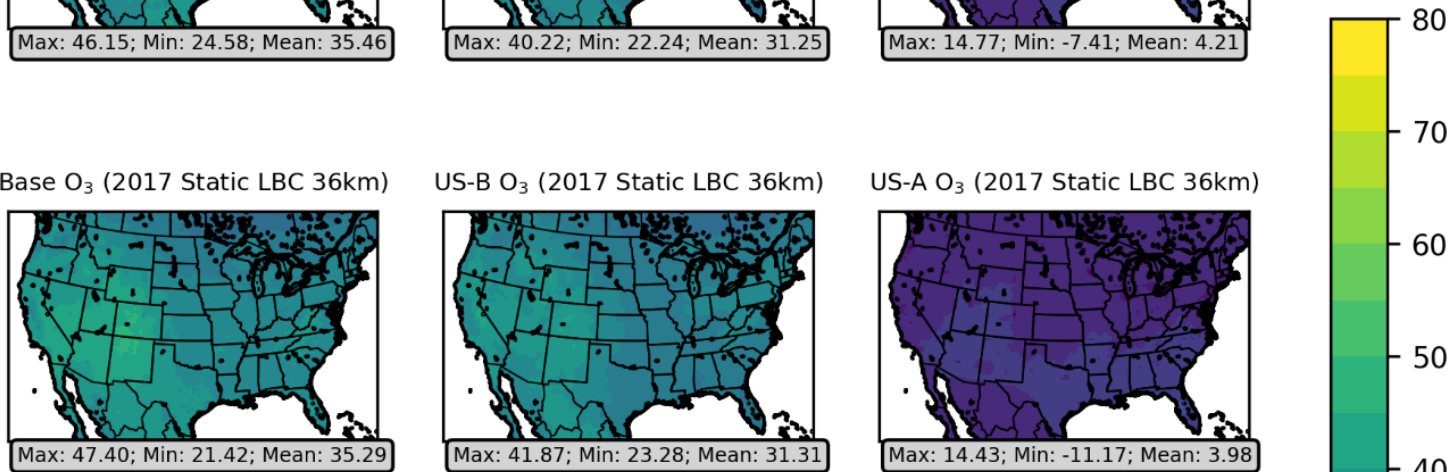

응

Base $\mathrm{O}_{3}(2016 \mathrm{CMAQ} 12 \mathrm{~km})$

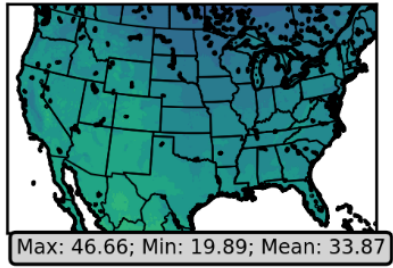

US-B $\mathrm{O}_{3}$ (2016 CMAQ 12km)

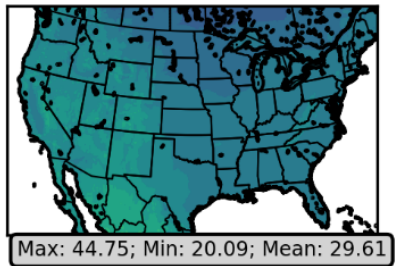

US-A O $\mathrm{O}_{3}(2016 \mathrm{CMAQ} 12 \mathrm{~km})$

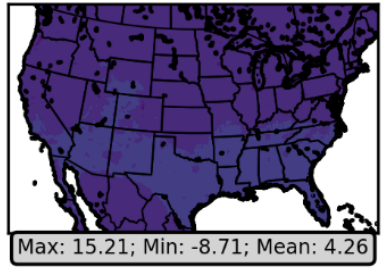

20

10

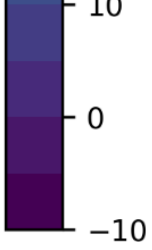

Base $\mathrm{O}_{3}(2016 \mathrm{HCMAQ} 108 \mathrm{~km})$
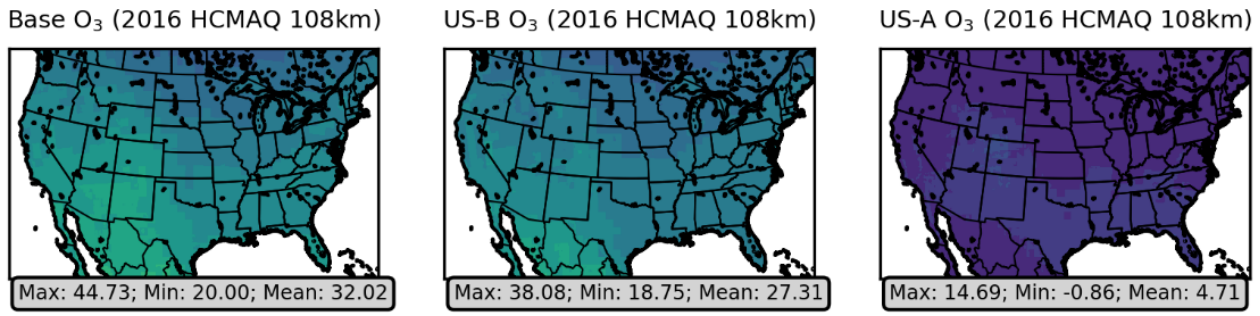

Figure S28. Winter (December, January, February) average of adjusted $\mathrm{O}_{3}$ concentration for all cases. Max, min, and mean refer to the maximum, minimum, and mean values over the contiguous US. 
Spring (MAM) Mean Simulated $\mathrm{O}_{3}$ Values

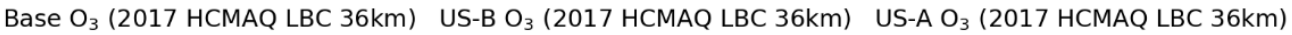
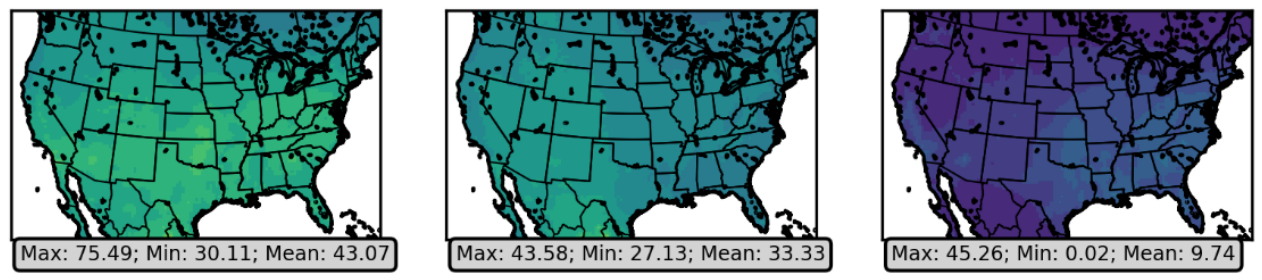

Base $\mathrm{O}_{3}$ (2017 Static LBC 36km)

US-B O $\mathrm{O}_{3}$ (2017 Static LBC 36km)
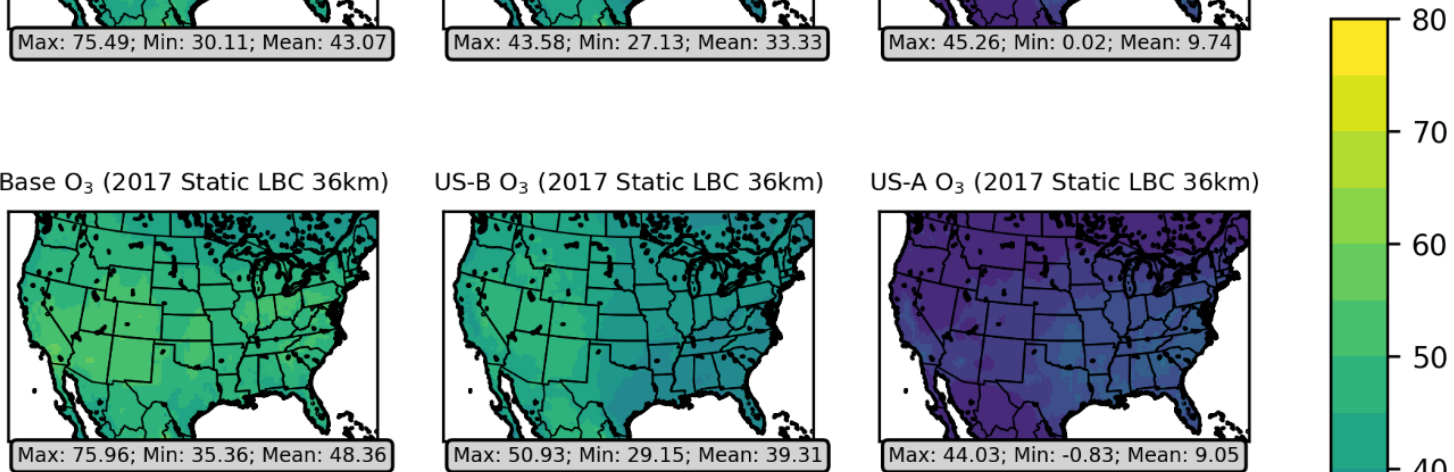

Base $\mathrm{O}_{3}(2016 \mathrm{CMAQ} 12 \mathrm{~km})$

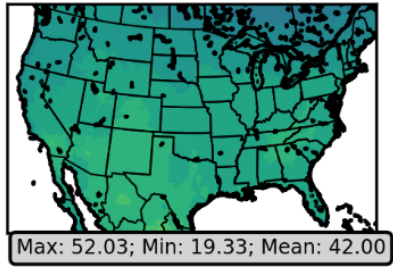

US-B $\mathrm{O}_{3}$ (2016 CMAQ 12km)
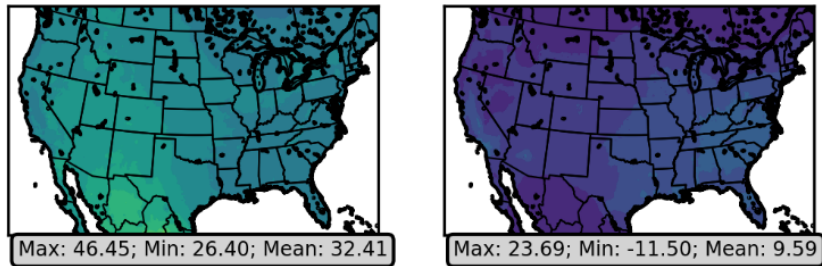

$-20$

$-10$

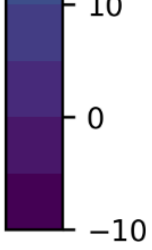

Base $\mathrm{O}_{3}(2016$ HCMAQ 108km)
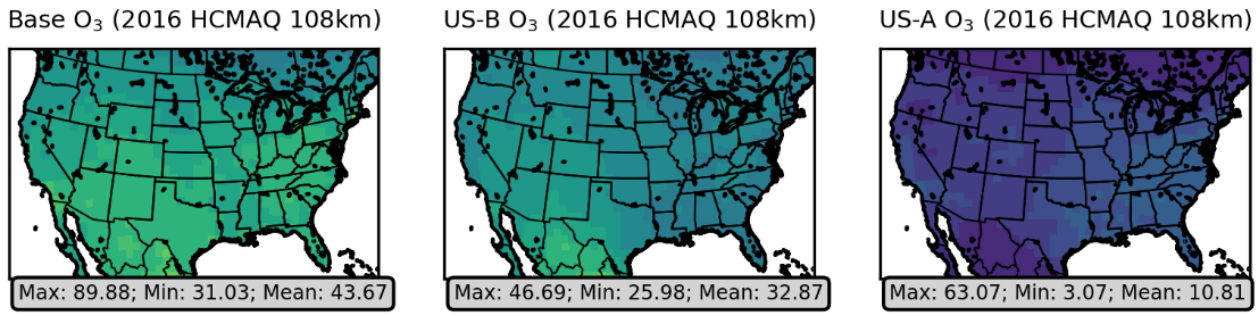

Figure S29. Spring (March, April, May) average of CMAQ-simulated $\mathrm{O}_{3}$ concentration for all cases. Max, min, and mean refer to the maximum, minimum, and mean values over the contiguous US. 
Spring (MAM) Mean Adjusted $\mathrm{O}_{3}$ Values

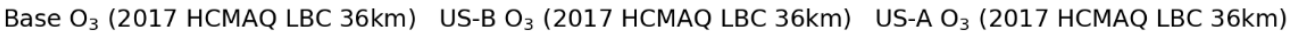
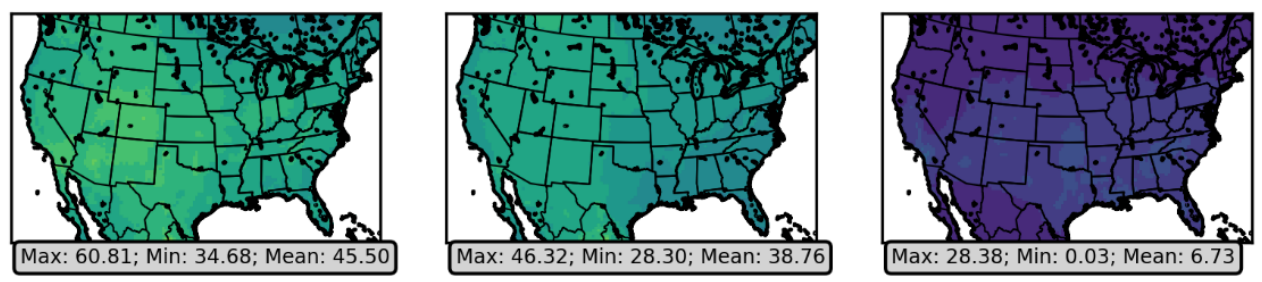

Base $\mathrm{O}_{3}$ (2017 Static LBC 36km)

US-B O $\mathrm{O}_{3}$ (2017 Static LBC 36km)
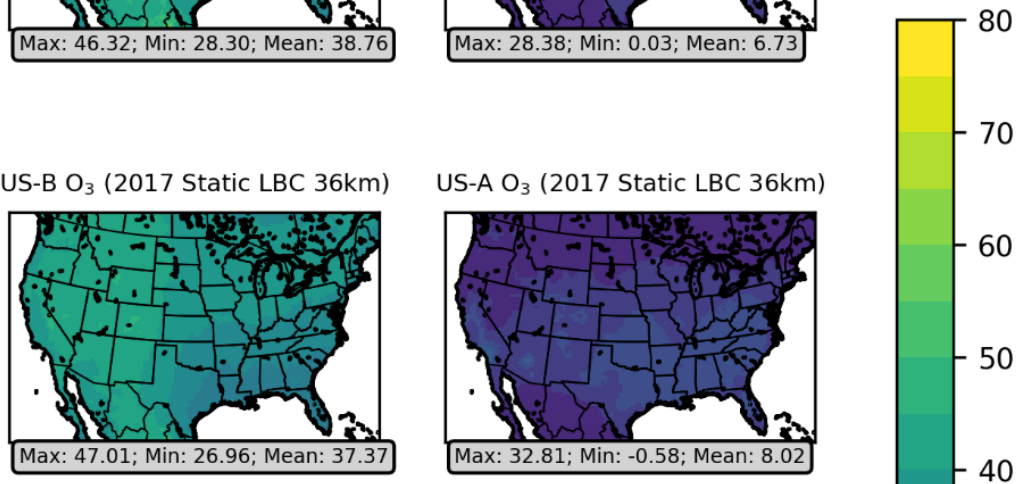

Base $\mathrm{O}_{3}(2016$ CMAQ $12 \mathrm{~km})$

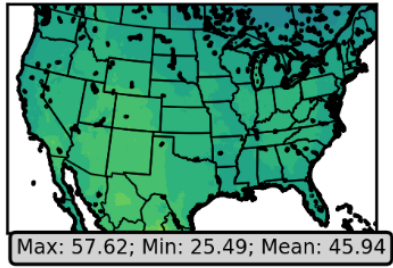

US-B $\mathrm{O}_{3}$ (2016 CMAQ 12km)

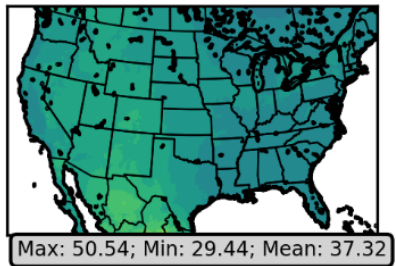

US-A O $\mathrm{O}_{3}(2016$ CMAQ $12 \mathrm{~km})$

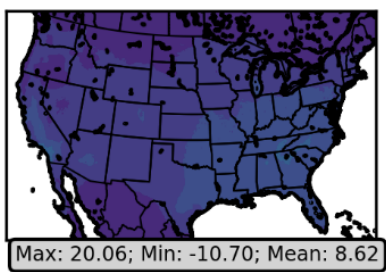

$-30$

$-20$

$-10$

10
0
-10

Base $\mathrm{O}_{3}(2016$ HCMAQ 108km)

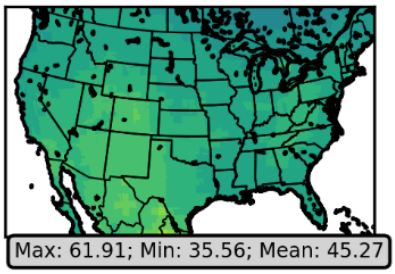

US-B O ${ }_{3}$ (2016 HCMAQ 108km)
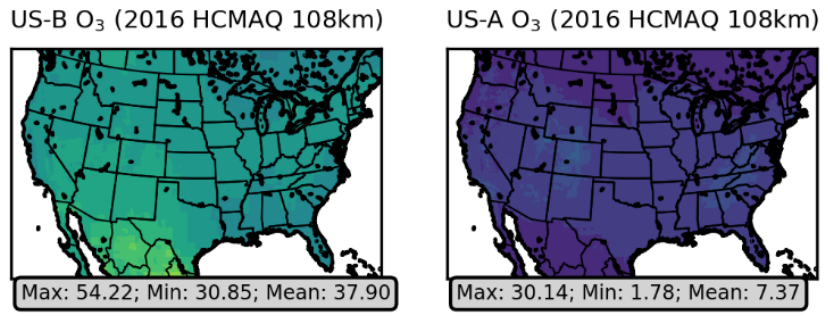

Figure S30. Spring (March, April, May) average of adjusted $\mathrm{O}_{3}$ concentration for all cases. Max, min, and mean refer to the maximum, minimum, and mean values over the contiguous US. 
Summer (JJA) Mean Simulated $\mathrm{O}_{3}$ Values

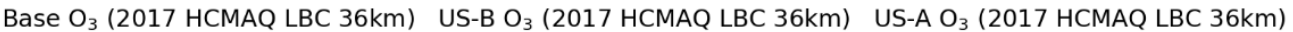
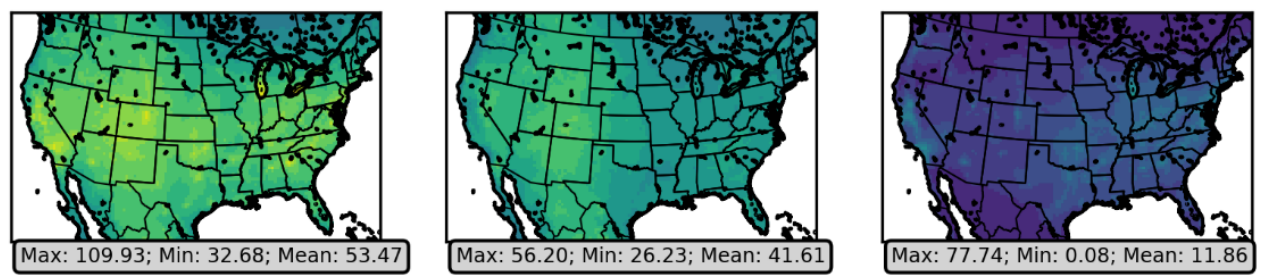

Base $\mathrm{O}_{3}$ (2017 Static LBC 36km)

US-B O $\mathrm{O}_{3}$ (2017 Static LBC 36km)
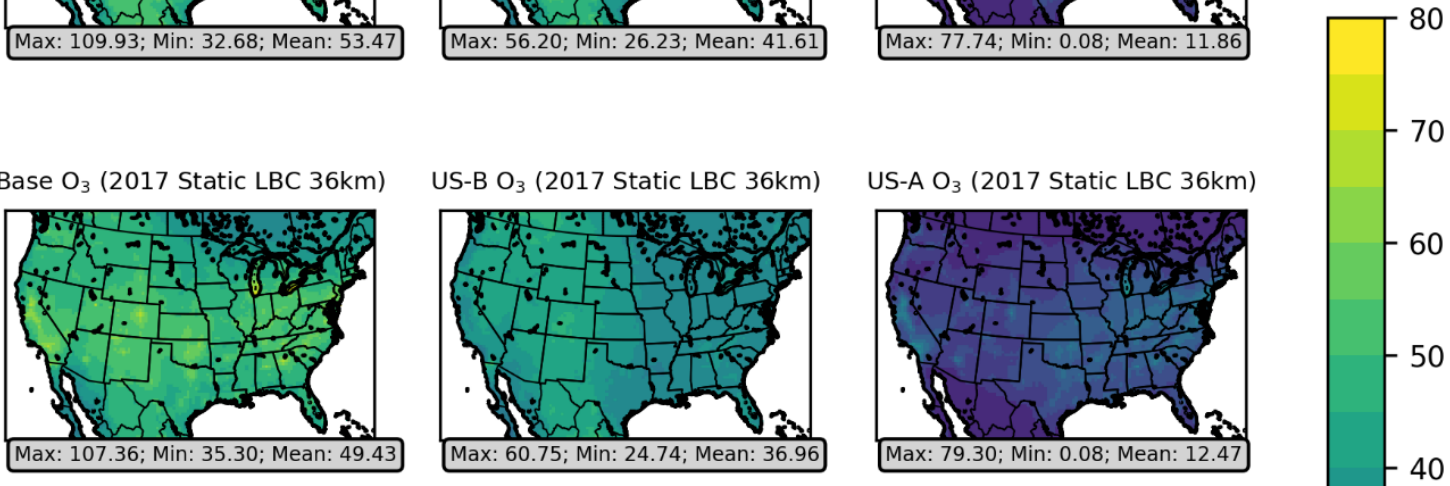

Base $\mathrm{O}_{3}(2016$ CMAQ $12 \mathrm{~km})$

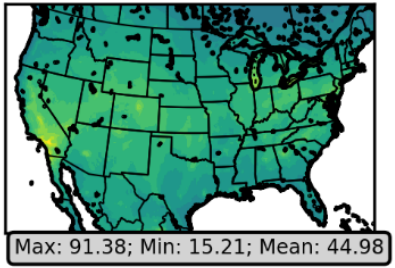

US-B $\mathrm{O}_{3}$ (2016 CMAQ 12km)

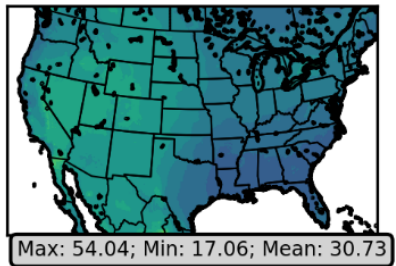

\section{을}

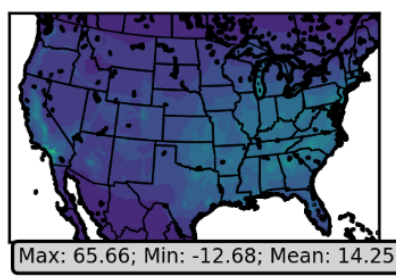

$-30$

$-20$

$-10$

$-0$

Base $\mathrm{O}_{3}$ (2016 HCMAQ 108km)
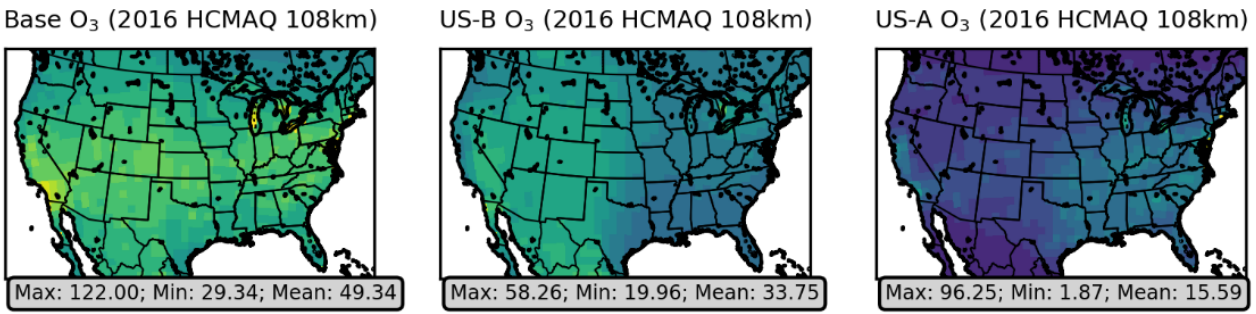

Figure S31. Summer (June, July, August) average of CMAQ-simulated $\mathrm{O}_{3}$ concentration for all cases. Max, min, and mean refer to the maximum, minimum, and mean values over the contiguous US. 
Summer (JJA) Mean Adjusted $\mathrm{O}_{3}$ Values

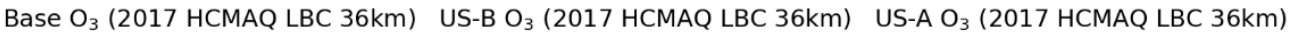
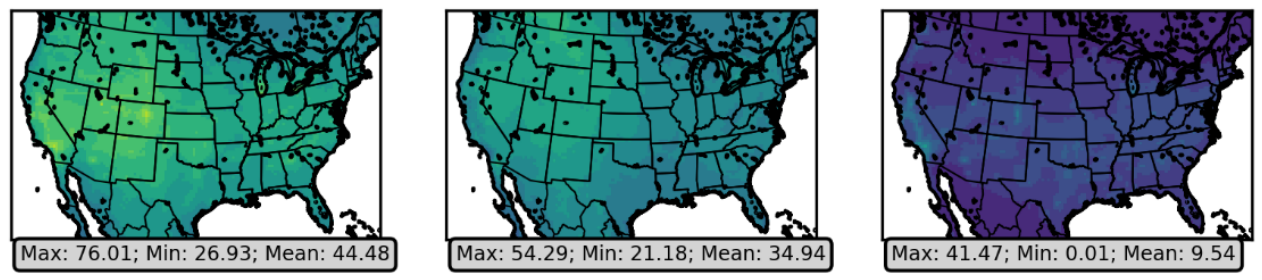

Base $\mathrm{O}_{3}$ (2017 Static LBC 36km)

US-B O $\mathrm{O}_{3}$ (2017 Static LBC 36km)
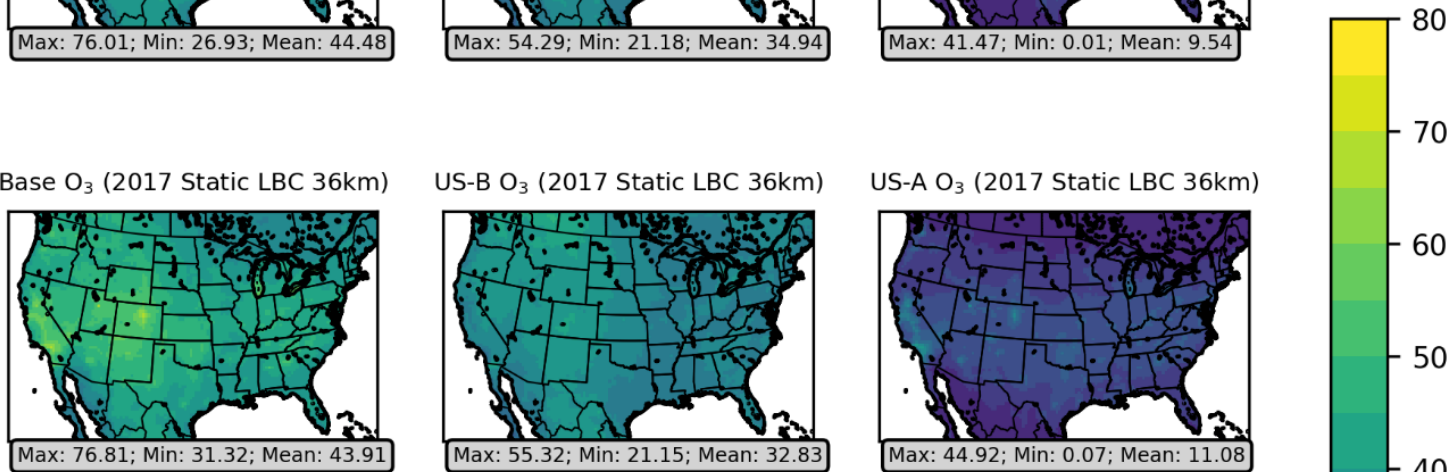

응

Base $\mathrm{O}_{3}(2016 \mathrm{CMAQ} 12 \mathrm{~km})$

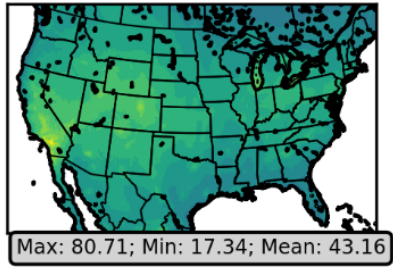

US-B $\mathrm{O}_{3}$ (2016 CMAQ 12km)
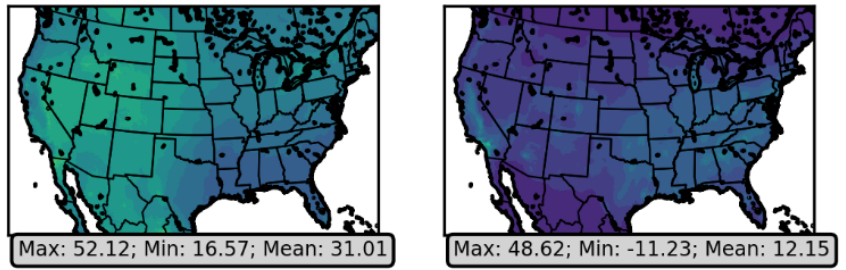

$-20$

$-10$

10
0
-10

Base $\mathrm{O}_{3}(2016$ HCMAQ 108km)
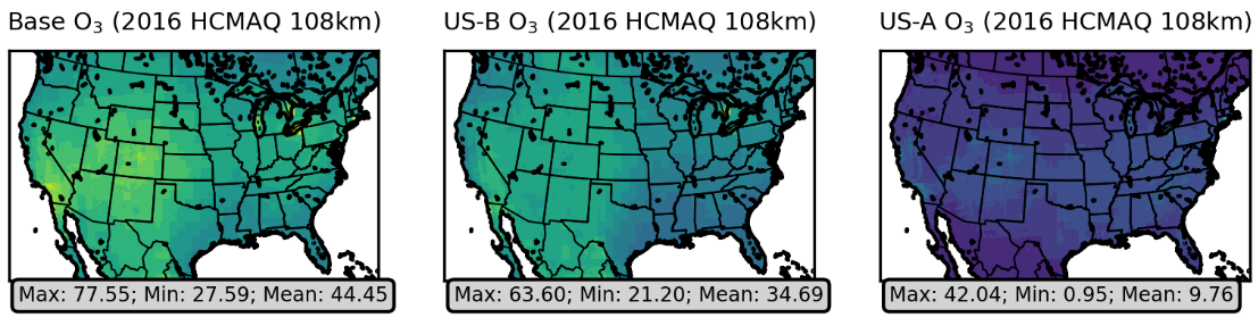

Figure S32. Summer (June, July, August) average of adjusted $\mathrm{O}_{3}$ concentration for all cases. Max, min, and mean refer to the maximum, minimum, and mean values over the contiguous US. 
Autumn (SON) Mean Simulated $\mathrm{O}_{3}$ Values

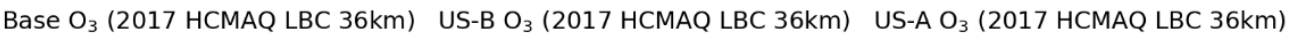
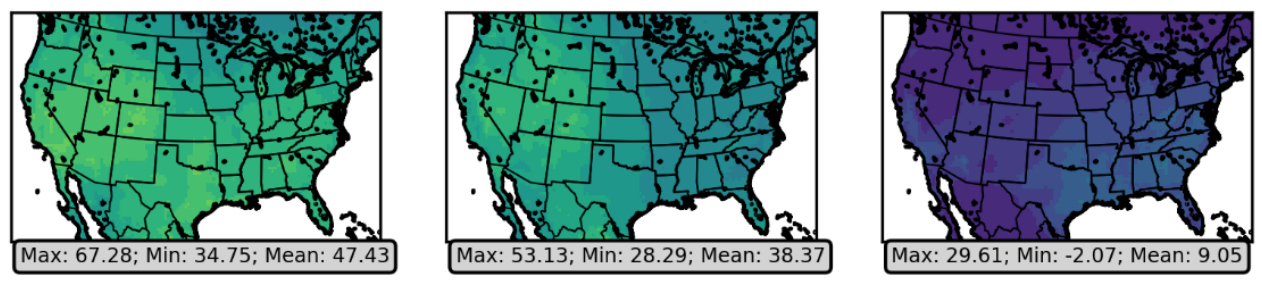

Base $\mathrm{O}_{3}(2017$ Static LBC $36 \mathrm{~km})$

US-B $\mathrm{O}_{3}$ (2017 Static LBC 36km)
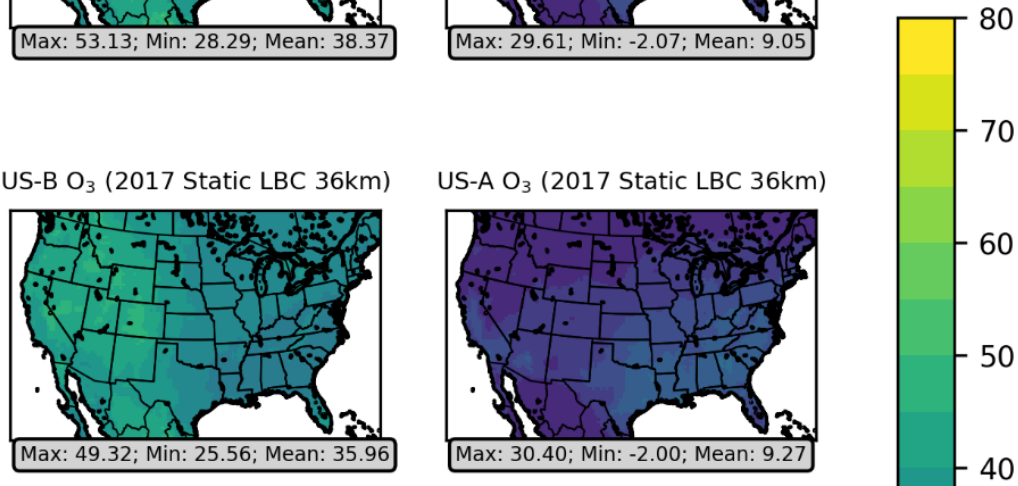

Base $\mathrm{O}_{3}(2016 \mathrm{CMAQ} 12 \mathrm{~km})$

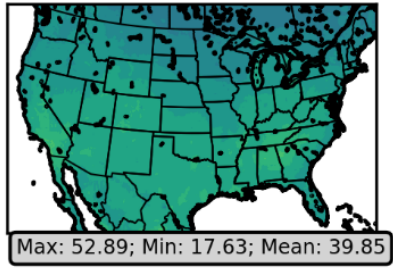

US-B $\mathrm{O}_{3}(2016$ CMAQ 12km)

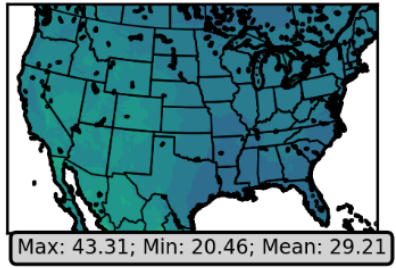

US-A O $\mathrm{O}_{3}(2016$ CMAQ 12km)

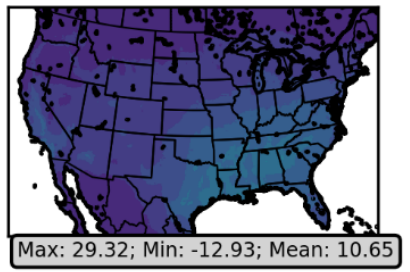

$-20$

$-10$

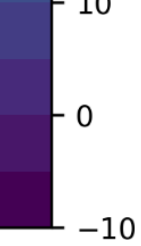

Base $\mathrm{O}_{3}(2016 \mathrm{HCMAQ} 108 \mathrm{~km})$
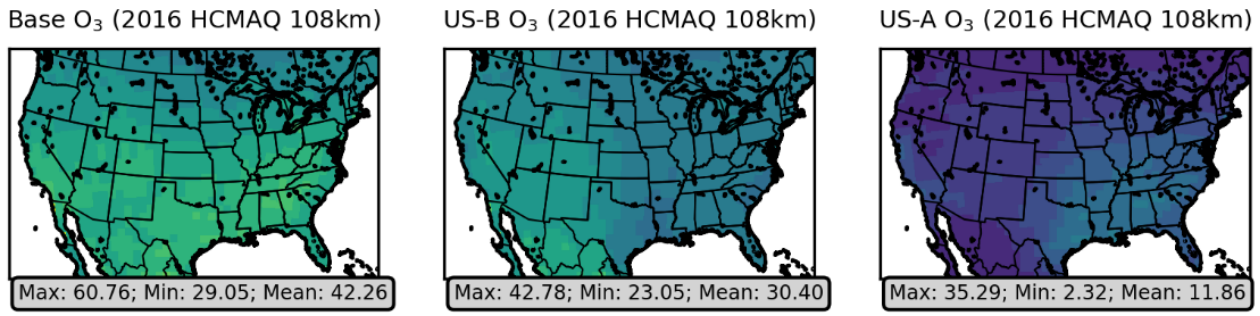

Figure S33. Autumn (September, October, November) average of CMAQ-simulated $\mathrm{O}_{3}$ concentration for all cases. Max, min, and mean refer to the maximum, minimum, and mean values over the contiguous US. 
Autumn (SON) Mean Adjusted $\mathrm{O}_{3}$ Values

Base $\mathrm{O}_{3}(2017$ HCMAQ LBC $36 \mathrm{~km})$ US-B O ( $_{3} 2017$ HCMAQ LBC $\left.36 \mathrm{~km}\right)$ US-A O 3 (2017 HCMAQ LBC 36km)
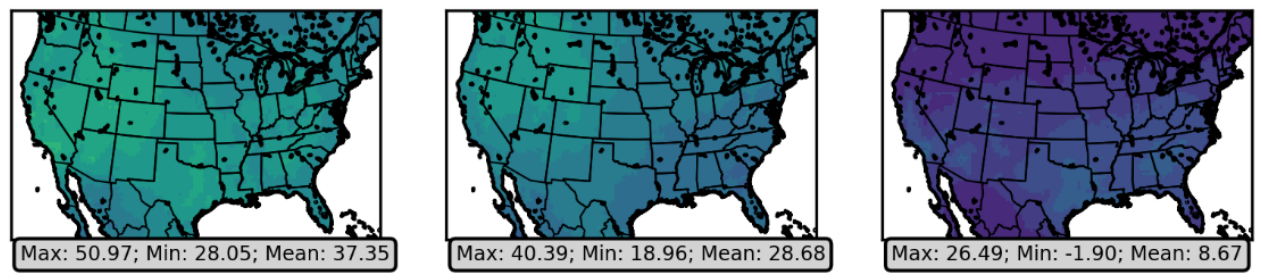

Base $\mathrm{O}_{3}$ (2017 Static LBC 36km)

US-B O $\mathrm{O}_{3}$ (2017 Static LBC 36km)
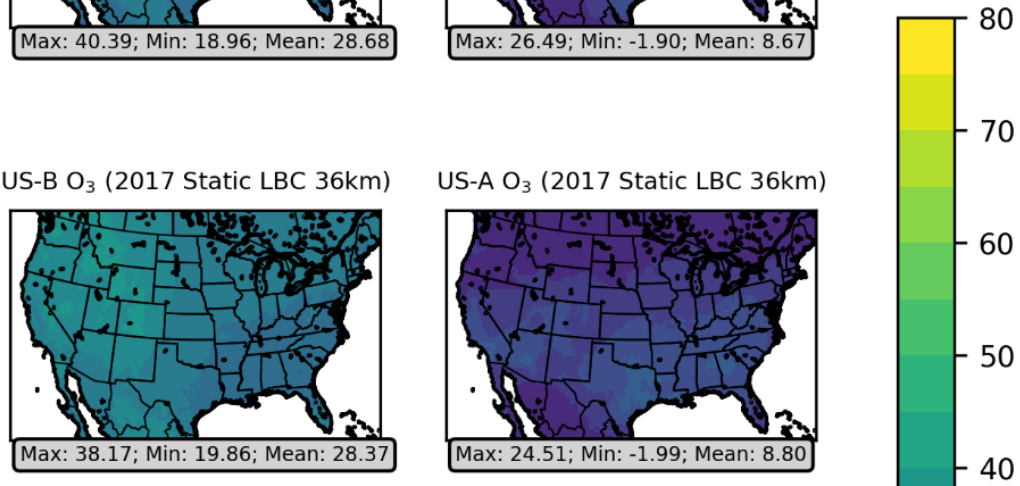

Base $\mathrm{O}_{3}(2016$ CMAQ $12 \mathrm{~km})$

US-B O $\mathrm{O}_{3}(2016$ CMAQ 12km)
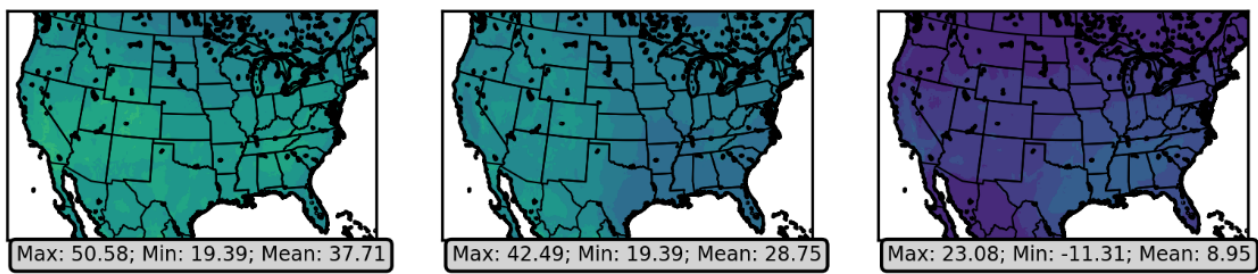

응

Base $\mathrm{O}_{3}(2016 \mathrm{HCMAQ} 108 \mathrm{~km})$
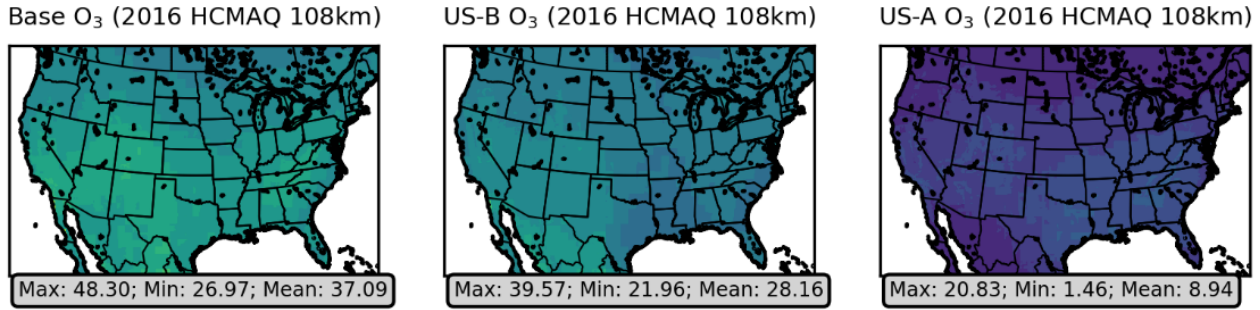

Max: 39.57; Min: 21.96; Mean: 28.16

Max: 20.83; Min: 1.46; Mean: 8.94

Figure S34. Autumn (September, October, November) average of adjusted $\mathrm{O}_{3}$ concentration for all cases. Max, min, and mean refer to the maximum, minimum, and mean values over the contiguous US. 


\section{Results from CASTNET Analysis}

The same analysis that was done for the full set of monitoring sites was also done for of subset of sites which only included sites from the Clean Air Status and Trends Network (CASTNET). Results of that analysis are shown here.

Table S17. Coefficients and $\mathrm{R}^{2}$ obtained by ozone regression model in Equation 1 (which does not include meteorological variables) for each simulation. The model resolution of each CTM simulation is given in parentheses. These results are for the analysis which only includes observations from CASTNET.

\begin{tabular}{|c|c|c|c|c|}
\hline & $\begin{array}{c}2017 \text { HCMAQ } \\
\text { LBC }(36 \mathrm{~km})\end{array}$ & $\begin{array}{c}2017 \text { Static LBC } \\
(36 \mathrm{~km})\end{array}$ & $\begin{array}{c}2016 \text { fine scale }(12 \\
\mathrm{km})\end{array}$ & $\begin{array}{c}2016 \text { coarse scale } \\
(108 \mathrm{~km})\end{array}$ \\
\hline$\alpha_{0, \text { US-B }}$ & 1.00 & 0.92 & 1.10 & 1.08 \\
\hline$\alpha_{0, \text { US-A }}$ & 0.81 & 0.93 & 0.88 & 0.78 \\
\hline$\alpha_{\mathrm{X}, \text { US-B }}$ & -0.0014 & -0.026 & -0.038 & -0.0085 \\
\hline$\alpha_{\mathrm{X}, \text { US-A }}$ & 0.17 & 0.23 & 0.15 & 0.084 \\
\hline$\alpha_{\text {Y,US-B }}$ & 0.037 & 0.012 & 0.017 & 0.027 \\
\hline$\alpha_{\text {Y,US-A }}$ & -0.033 & 0.0011 & -0.012 & -0.023 \\
\hline$\alpha_{\mathrm{Z}, \text { US-B }}$ & 0.0066 & 0.018 & 0.037 & 0.032 \\
\hline$\alpha_{Z, \text { ZS-A }}$ & 0.087 & 0.10 & -0.053 & 0.0029 \\
\hline$\alpha_{\text {sin,US-B }}$ & 0.20 & 0.056 & 0.085 & 0.089 \\
\hline$\alpha_{\text {sin,US-A }}$ & -0.11 & -0.010 & 0.019 & 0.037 \\
\hline$\alpha_{\text {cos,US-B }}$ & 0.046 & -0.036 & 0.042 & 0.058 \\
\hline$\alpha_{\text {cos,US-A }}$ & 0.088 & 0.092 & -0.018 & 0.014 \\
\hline $\mathrm{R}^{2}$ & 0.47 & 0.50 & 0.65 & 0.59 \\
\hline
\end{tabular}


Annual Mean $\alpha$ Values
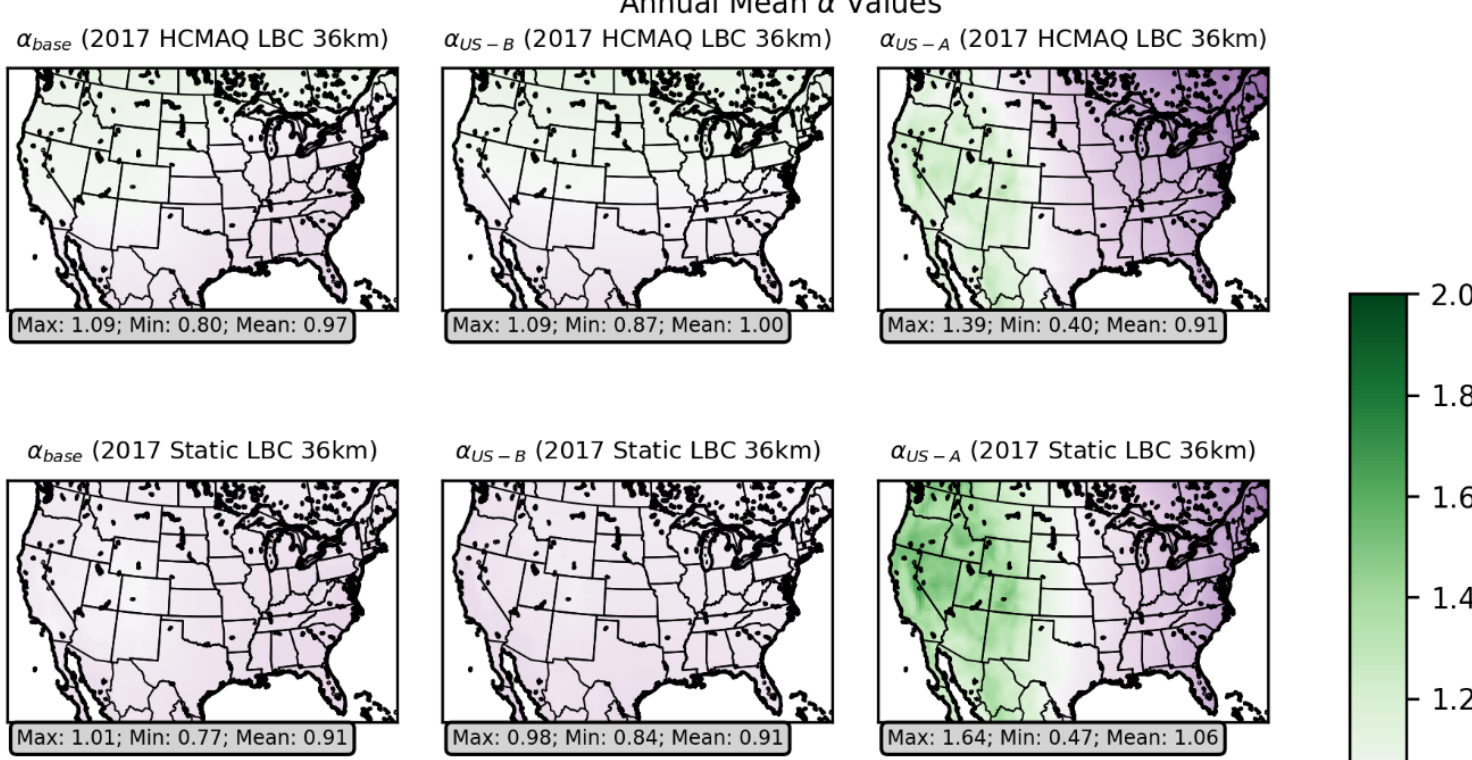

1.8

$-1.6$

1.4

1.2

1.0

$\alpha_{\text {base }}(2016$ CMAQ 12km)
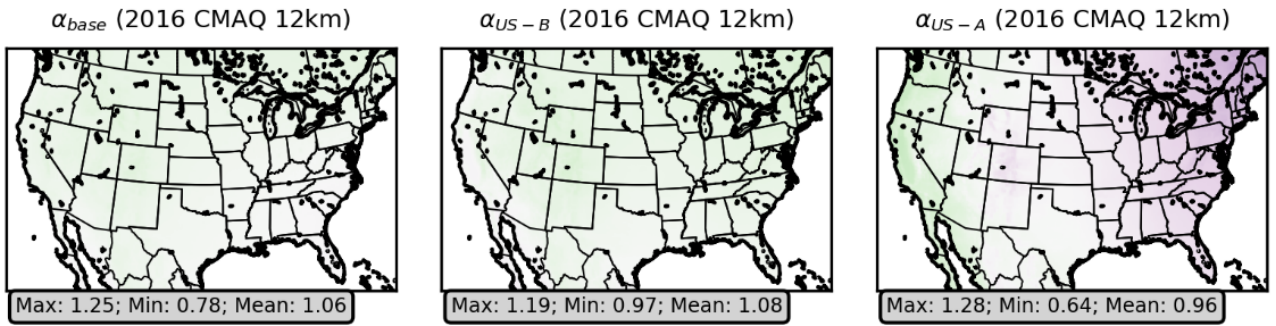

$-0.8$

0.8

0.6

$-0.4$

0.2
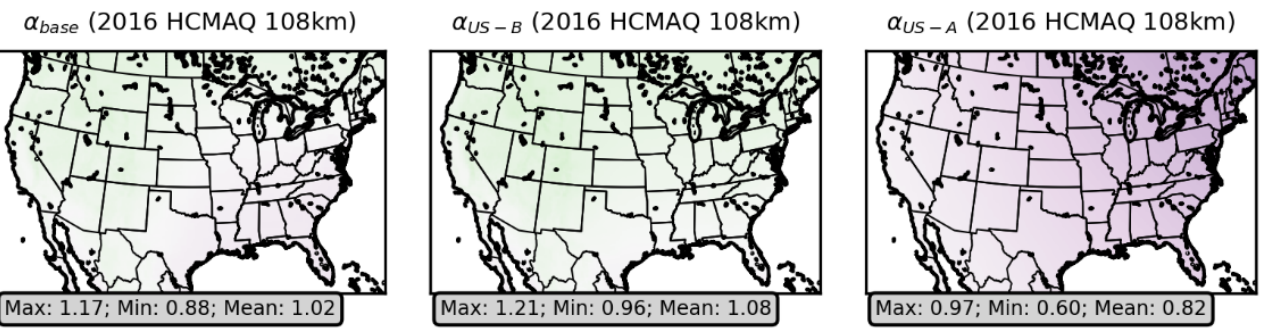

Figure S35. Annual average of $\mathrm{O}_{3}$ adjustment ratios for all cases. Max, min, and mean refer to the maximum, minimum, and mean values over the contiguous US. $\alpha=\left[\mathrm{O}_{3}\right]^{\text {simulated }} /\left[\mathrm{O}_{3}\right]^{\text {adjusted }}$. These results are for the analysis which only includes observations from CASTNET. 
Annual Mean $\Delta \mathrm{O}_{3}$ Values

$\triangle$ Base $\mathrm{O}_{3}(2017$ HCMAQ LBC 36km) $\triangle$ US-B O 3 (2017 HCMAQ LBC 36km) $\triangle$ US-A O 3 (2017 HCMAQ LBC 36km)
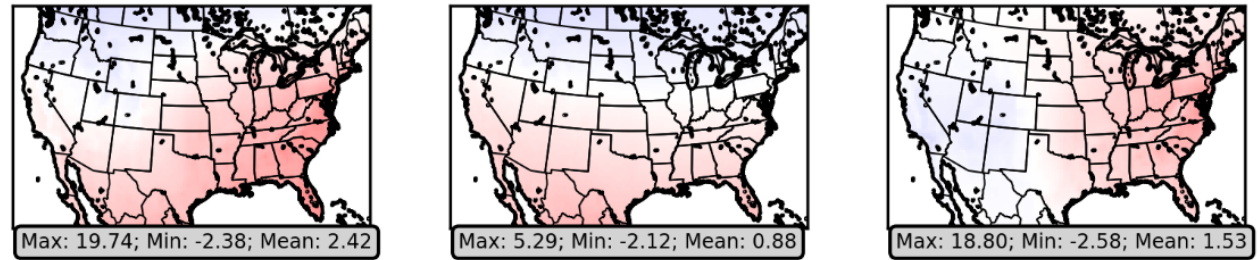

$\triangle$ Base $\mathrm{O}_{3}$ (2017 Static LBC $36 \mathrm{~km}$ )
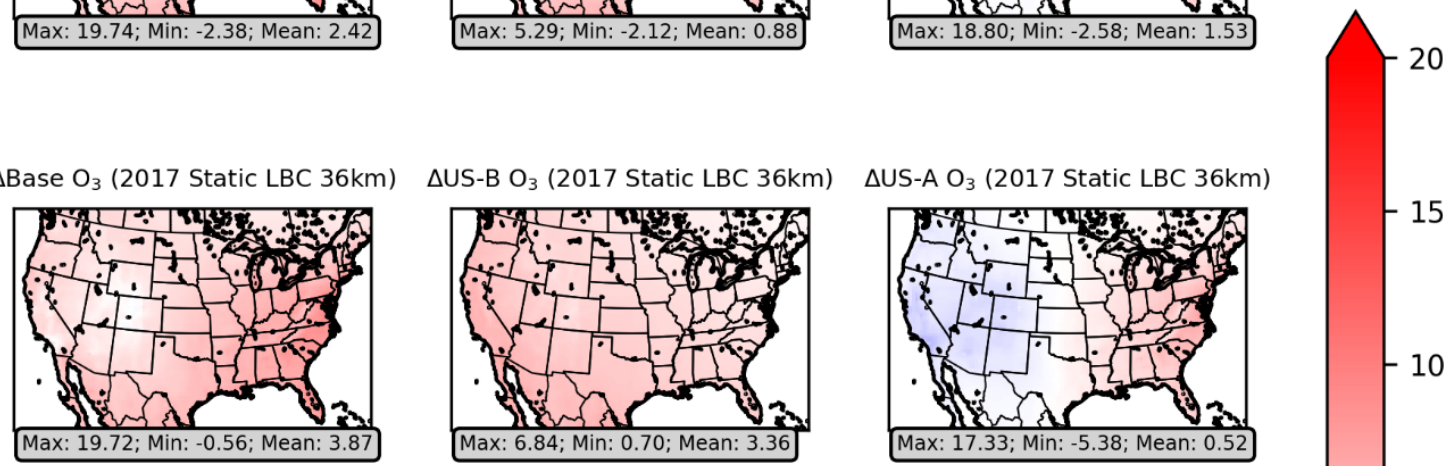

$\triangle$ Base $\mathrm{O}_{3}(2016 \mathrm{CMAQ} 12 \mathrm{~km})$

$\triangle$ US-B O 3 (2016 CMAQ $12 \mathrm{~km})$
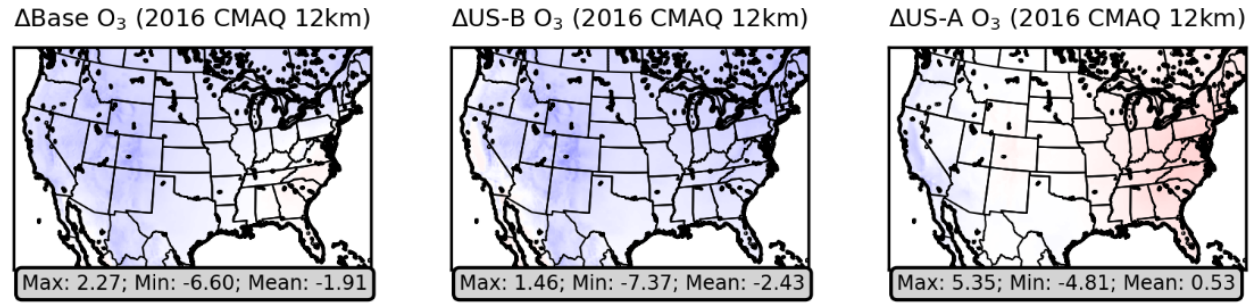

$\triangle$ Base $\mathrm{O}_{3}(2016 \mathrm{HCMAQ} 108 \mathrm{~km})$

$\triangle \mathrm{US}-\mathrm{B} \mathrm{O}_{3}(2016 \mathrm{HCMAQ} 108 \mathrm{~km})$

$\triangle$ US-A O $\mathrm{O}_{3}(2016$ HCMAQ $108 \mathrm{~km})$
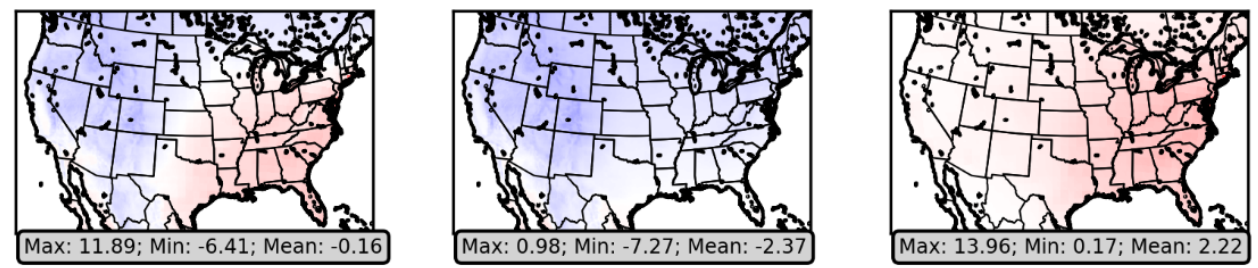

Figure S36. Annual average of $\mathrm{O}_{3}$ adjustments for all cases. Max, min, and mean refer to the maximum, minimum, and mean values over the contiguous US. $\Delta=\left[\mathrm{O}_{3}\right]^{\text {simulated }}-\left[\mathrm{O}_{3}\right]^{\text {adjusted }}=(1$ $-\alpha)^{*}\left[\mathrm{O}_{3}\right]^{\text {simulated }}$. These results are for the analysis which only includes observations from CASTNET. 


\section{Remote Observation Site Comparison}

The CMAQ-simulated and adjusted US- $\mathrm{B} \mathrm{O}_{3}$ was compared to observations at remote monitoring sites which are not affected much by US anthropogenic emissions. We have added comparisons of the simulated and adjusted US- $\mathrm{B} \mathrm{O}_{3}$ to observed $\mathrm{O}_{3}$ at Mount Bachelor Observatory, Oregon, (https://digital.lib.washington.edu/researchworks/handle/1773/43750) and Trinidad Head, California, (https://www.esrl.noaa.gov/gmd/) neither of which are included in the regression model training data set. We have also added comparisons to observed $\mathrm{O}_{3}$ at Cheeka Peak, Washington, which was included in the regression model training data set. We do note however, that the $\mathrm{O}_{3}$ concentrations observed at remote sites represent "baseline $\mathrm{O}_{3}$ " rather than "background $\mathrm{O}_{3}$." While remote sites are far removed from local anthropogenic emission sources, there may be some effects from US anthropogenic emissions that do impact the remote sites. The results are mixed for different sites and different CMAQ simulation cases. Mostly the adjustment to US- $\mathrm{B} \mathrm{O}_{3}$ results in either improvement or no change in agreement between estimated US-B and observed $\mathrm{O}_{3}$. The exception to this is for the 2016 simulations at the Cheeka Peak site where the adjustment resulted in poorer correlation though with little change in bias or error. The tables below summarize the results of the remote site comparisons.

Table S18. Comparison of CTM-simulated and adjusted US-B $\mathrm{O}_{3}$ to observed $\mathrm{O}_{3}$ at selected remote monitoring sites for 2017 simulations.

\begin{tabular}{|c|c|c|c|c|c|c|c|c|c|}
\hline Site & Case & $\mathrm{N}$ & $\begin{array}{c}\text { Uean } \\
(\mathrm{ppb})\end{array}$ & $\begin{array}{c}\text { Mean } \\
\text { Observed } \\
(\mathrm{ppb})\end{array}$ & $\begin{array}{c}\mathrm{MB} \\
(\mathrm{ppb})\end{array}$ & $\begin{array}{c}\text { ME } \\
(\mathrm{ppb})\end{array}$ & $\begin{array}{c}\text { NMB } \\
(\%)\end{array}$ & $\begin{array}{c}\text { NME } \\
(\%)\end{array}$ & $\mathrm{r}$ \\
\hline $\begin{array}{c}\text { Mt. } \\
\text { Bachelor, } \\
\text { OR }\end{array}$ & $\begin{array}{c}\text { HCMAQ } \\
\text { LBC } \\
\text { Simulated }\end{array}$ & 150 & 32.43 & 51.83 & -19.39 & 19.72 & -37.42 & 38.05 & 0.34 \\
\hline
\end{tabular}




\begin{tabular}{|c|c|c|c|c|c|c|c|c|c|}
\hline & $\begin{array}{l}\text { HCMAQ } \\
\text { LBC } \\
\text { Adjusted }\end{array}$ & 150 & 37.66 & 51.83 & -14.17 & 14.64 & -27.34 & 28.25 & 0.31 \\
\hline & $\begin{array}{c}\text { Static } \\
\text { LBC } \\
\text { Simulated }\end{array}$ & 150 & 42.56 & 51.83 & -9.27 & 10.42 & -17.89 & 20.11 & 0.10 \\
\hline & $\begin{array}{c}\text { Static } \\
\text { LBC } \\
\text { Adjusted }\end{array}$ & 150 & 39.26 & 51.83 & -12.57 & 13.15 & -24.25 & 25.36 & 0.21 \\
\hline \multirow{4}{*}{$\begin{array}{r}\text { Trinidad } \\
\text { Head, CA }\end{array}$} & $\begin{array}{l}\text { HCMAQ } \\
\text { LBC } \\
\text { Simulated }\end{array}$ & 140 & 30.69 & 35.80 & -5.11 & 6.97 & -14.27 & 19.48 & 0.61 \\
\hline & $\begin{array}{l}\text { HCMAQ } \\
\text { LBC } \\
\text { Adjusted }\end{array}$ & 140 & 37.48 & 35.80 & 1.68 & 4.28 & 4.69 & 11.96 & 0.65 \\
\hline & $\begin{array}{c}\text { Static } \\
\text { LBC } \\
\text { Simulated }\end{array}$ & 140 & 42.59 & 35.80 & 6.80 & 7.70 & 18.98 & 21.52 & 0.43 \\
\hline & $\begin{array}{c}\text { Static } \\
\text { LBC } \\
\text { Adjusted }\end{array}$ & 140 & 38.76 & 35.80 & 2.96 & 5.01 & 8.28 & 13.98 & 0.58 \\
\hline \multirow{4}{*}{$\begin{array}{l}\text { Cheeka } \\
\text { Peak, } \\
\text { WA }\end{array}$} & $\begin{array}{l}\text { HCMAQ } \\
\text { LBC } \\
\text { Simulated }\end{array}$ & 309 & 34.67 & 36.16 & -1.49 & 8.27 & -4.11 & 22.88 & 0.23 \\
\hline & $\begin{array}{l}\text { HCMAQ } \\
\text { LBC } \\
\text { Adjusted }\end{array}$ & 309 & 37.73 & 36.16 & 1.57 & 5.20 & 4.35 & 14.38 & 0.61 \\
\hline & $\begin{array}{c}\text { Static } \\
\text { LBC } \\
\text { Simulated }\end{array}$ & 309 & 41.78 & 36.16 & 5.62 & 7.72 & 15.55 & 21.35 & 0.41 \\
\hline & $\begin{array}{c}\text { Static } \\
\text { LBC } \\
\text { Adjusted }\end{array}$ & 309 & 37.46 & 36.16 & 1.30 & 5.47 & 3.60 & 15.12 & 0.50 \\
\hline
\end{tabular}


Table S19. Comparison of CTM-simulated and adjusted US-B $\mathrm{O}_{3}$ to observed $\mathrm{O}_{3}$ at selected remote monitoring sites for 2016 simulations.

\begin{tabular}{|c|c|c|c|c|c|c|c|c|c|}
\hline Site & Case & $\mathrm{N}$ & $\begin{array}{l}\text { Mean } \\
\text { US-B } \\
\text { (ppb) }\end{array}$ & $\begin{array}{c}\text { Mean } \\
\text { Observed } \\
(\mathrm{ppb})\end{array}$ & $\begin{array}{c}\text { MB } \\
(\mathrm{ppb})\end{array}$ & $\begin{array}{c}\text { ME } \\
(\mathrm{ppb})\end{array}$ & $\begin{array}{c}\text { NMB } \\
(\%)\end{array}$ & $\begin{array}{c}\text { NME } \\
(\%)\end{array}$ & $\mathrm{r}$ \\
\hline \multirow{4}{*}{$\begin{array}{c}\text { Mt. } \\
\text { Bachelor, } \\
\text { OR }\end{array}$} & $\begin{array}{c}\text { CMAQ } \\
12 \mathrm{~km} \\
\text { Simulated }\end{array}$ & 344 & 28.15 & 50.53 & -22.38 & 22.38 & -44.29 & 44.29 & -0.06 \\
\hline & $\begin{array}{c}\text { CMAQ } \\
12 \mathrm{~km} \\
\text { Adjusted }\end{array}$ & 344 & 28.78 & 50.53 & -21.75 & 21.75 & -43.04 & 43.04 & -0.07 \\
\hline & $\begin{array}{l}\text { HCMAQ } \\
\text { 108km } \\
\text { Simulated }\end{array}$ & 344 & 28.41 & 50.53 & -22.12 & 22.12 & -43.78 & 43.78 & -0.10 \\
\hline & $\begin{array}{c}\text { HCMAQ } \\
\text { 108km } \\
\text { Adjusted }\end{array}$ & 344 & 29.31 & 50.53 & -21.22 & 21.23 & -41.99 & 42.01 & -0.05 \\
\hline \multirow{4}{*}{$\begin{array}{c}\text { Trinidad } \\
\text { Head, CA }\end{array}$} & $\begin{array}{c}\text { CMAQ } \\
12 \mathrm{~km} \\
\text { Simulated }\end{array}$ & 363 & 28.63 & 28.82 & -0.19 & 5.03 & -0.65 & 17.47 & 0.57 \\
\hline & $\begin{array}{l}\text { CMAQ } \\
12 \mathrm{~km} \\
\text { Adjusted }\end{array}$ & 363 & 29.12 & 28.82 & 0.30 & 4.35 & 1.05 & 15.11 & 0.70 \\
\hline & $\begin{array}{l}\text { HCMAQ } \\
\text { 108km } \\
\text { Simulated }\end{array}$ & 363 & 28.30 & 28.82 & -0.52 & 5.16 & -1.81 & 17.90 & 0.56 \\
\hline & $\begin{array}{c}\text { HCMAQ } \\
108 \mathrm{~km} \\
\text { Adjusted }\end{array}$ & 363 & 29.08 & 28.82 & 0.27 & 4.47 & 0.93 & 15.52 & 0.69 \\
\hline \multirow{2}{*}{$\begin{array}{l}\text { Cheeka } \\
\text { Peak, } \\
\text { WA }\end{array}$} & $\begin{array}{c}\text { CMAQ } \\
12 \mathrm{~km} \\
\text { Simulated }\end{array}$ & 345 & 28.23 & 36.14 & -7.91 & 9.12 & -21.89 & 25.24 & 0.47 \\
\hline & $\begin{array}{c}\text { CMAQ } \\
12 \mathrm{~km} \\
\text { Adjusted }\end{array}$ & 345 & 27.89 & 36.14 & -8.26 & 9.63 & -22.84 & 26.64 & 0.38 \\
\hline
\end{tabular}




\begin{tabular}{|c|c|c|c|c|c|c|c|c|c|}
\hline $\begin{array}{c}\text { HCMAQ } \\
108 \mathrm{~km} \\
\text { Simulated }\end{array}$ & 345 & 29.06 & 36.14 & -7.08 & 8.11 & -19.58 & 22.45 & 0.62 \\
\hline $\begin{array}{c}\text { HCMAQ } \\
108 \mathrm{~km} \\
\text { Adjusted }\end{array}$ & 345 & 28.91 & 36.14 & -7.23 & 8.54 & -20.00 & 23.62 & 0.54 \\
\hline
\end{tabular}




\section{SI REFERENCES}

1. Henderson, B. H.; Dolwick, P.; Jang, C.; Eyth, A.; Vukovich, J.; Mathur, R.; Hogrefe, C.; Pouliot, G.; Timin, B.; Appel, K. W., Global Sources of North American Ozone. In 2019 CMAS Conference, 2019.

2. USEPA, Technical Support Document (TSD) Preparation of Emissions Inventories for the Version 7.12016 North American Emissions Modeling Platform. 2019.

3. USEPA, Technical Support Document (TSD) Preparation of Emissions Inventories for the Version 6.3, 2011 Emissions Modeling Platform. 2016.

4. USEPA, Technical Support Document (TSD) Preparation of Emissions Inventories for the Version 7.1 2016 Hemispheric Emissions Modeling Platform. 2019.

5. Zhao, B.; Zheng, H.; Wang, S.; Smith, K. R.; Lu, X.; Aunan, K.; Gu, Y.; Wang, Y.; Ding, D.; Xing, J.; Fu, X.; Yang, X.; Liou, K.-N.; Hao, J., Change in household fuels dominates the decrease in $\mathrm{PM}<\mathrm{sub}>2.5</$ sub $>$ exposure and premature mortality in China in 20052015. Proceedings of the National Academy of Sciences 2018, 115, (49), 12401-12406, DOI: $10.1073 /$ pnas.1812955115.

6. Li, M.; Zhang, Q.; Kurokawa, J. I.; Woo, J. H.; He, K.; Lu, Z.; Ohara, T.; Song, Y.; Streets, D. G.; Carmichael, G. R.; Cheng, Y.; Hong, C.; Huo, H.; Jiang, X.; Kang, S.; Liu, F.; Su, H.; Zheng, B., MIX: a mosaic Asian anthropogenic emission inventory under the international collaboration framework of the MICS-Asia and HTAP. Atmos. Chem. Phys. 2017, 17, (2), 935-963, DOI: 10.5194/acp-17-935-2017.

7. Kang, D.; Pickering, K. E.; Allen, D. J.; Foley, K. M.; Wong, D. C.; Mathur, R.; Roselle, S. J., Simulating lightning NO production in CMAQv5.2: evolution of scientific updates. Geosci. Model Dev. 2019, 12, (7), 3071-3083, DOI: 10.5194/gmd-12-3071-2019. 
8. Wiedinmyer, C.; Akagi, S. K.; Yokelson, R. J.; Emmons, L. K.; Al-Saadi, J. A.; Orlando, J. J.; Soja, A. J., The Fire INventory from NCAR (FINN): a high resolution global model to estimate the emissions from open burning. Geosci. Model Dev. 2011, 4, (3), 625-641, DOI: 10.5194/gmd-4-625-2011.

9. USEPA, 2017 National Emissions Inventory Technical Support Document. 2020.

10. Xing, J.; Mathur, R.; Pleim, J.; Hogrefe, C.; Wang, J.; Gan, C. M.; Sarwar, G.; Wong, D. C.; McKeen, S., Representing the effects of stratosphere-troposphere exchange on 3-D O3 distributions in chemistry transport models using a potential vorticity-based parameterization. Atmos. Chem. Phys. 2016, 16, (17), 10865-10877, DOI: 10.5194/acp-1610865-2016.

11. Mathur, R.; Xing, J.; Gilliam, R.; Sarwar, G.; Hogrefe, C.; Pleim, J.; Pouliot, G.; Roselle, S.; Spero, T. L.; Wong, D. C.; Young, J., Extending the Community Multiscale Air Quality (CMAQ) Modeling System to Hemispheric Scales: Overview of Process Considerations and Initial Applications. Atmos Chem Phys 2017, 17, 12449-12474, DOI: 10.5194/acp-17$12449-2017$.

12. Foroutan, H.; Young, J.; Napelenok, S.; Ran, L.; Appel, K. W.; Gilliam, R. C.; Pleim, J. E., Development and evaluation of a physics-based windblown dust emission scheme implemented in the CMAQ modeling system. Journal of Advances in Modeling Earth Systems 2017, 9, (1), 585-608, DOI: 10.1002/2016ms000823.

13. Gantt, B.; Kelly, J. T.; Bash, J. O., Updating sea spray aerosol emissions in the Community Multiscale Air Quality (CMAQ) model version 5.0.2. Geosci. Model Dev. 2015, 8, (11), 3733-3746, DOI: 10.5194/gmd-8-3733-2015. 